WIDER Working Paper 2020/168

Inequality and the changing nature of work in Peru

Paola Ballon ${ }^{1}$ and Jorge Dávalos ${ }^{2}$

December 2020

United Nations University World Institute for Development Economics Research 
Abstract: This paper identifies the socioeconomic drivers of earnings inequality in Peru in the period 2004-18. Using the ENAHO household surveys and data on routine task content of occupations, we apply inequality decomposition methods to the real earnings distribution, its quantiles, and the Gini index. We find that in this period inequality has reduced, with great improvement attributed to reductions in the gender wage gap and macroeconomic factors. However, we did not find strong evidence for factors related to changes in workers' attributes or shifts in job characteristics, except for a slight enhancing effect of the task content of occupations, which increases in importance as we move from 'poorer' to 'richer' deciles.

Key words: real earnings, decomposition methods, inequality, Peru

JEL classification: C3, I21, I31, O54

Supplementary material: Data Appendix is available on the working paper's webpage.

${ }^{1}$ Smith School of Enterprise and the Environment, University of Oxford, Oxford, UK; ${ }^{2}$ Universidad del Pacífico, Lima, Peru, and Partnership for Economic Policy (PEP); corresponding author: paola.m.ballon@gmail.com

This study has been prepared within the UNU-WIDER project The changing nature of work and inequality.

Copyright (C) UNU-WIDER 2020

Information and requests: publications@wider.unu.edu

ISSN 1798-7237 ISBN 978-92-9256-925-9

https://doi.org/10.35188/UNU-WIDER/2020/925-9

Typescript prepared by Gary Smith.

United Nations University World Institute for Development Economics Research provides economic analysis and policy advice with the aim of promoting sustainable and equitable development. The Institute began operations in 1985 in Helsinki, Finland, as the first research and training centre of the United Nations University. Today it is a unique blend of think tank, research institute, and UN agency—providing a range of services from policy advice to governments as well as freely available original research.

The Institute is funded through income from an endowment fund with additional contributions to its work programme from Finland, Sweden, and the United Kingdom as well as earmarked contributions for specific projects from a variety of donors.

Katajanokanlaituri 6 B, 00160 Helsinki, Finland

The views expressed in this paper are those of the author(s), and do not necessarily reflect the views of the Institute or the United Nations University, nor the programme/project donors. 
Peru's latest trade liberalization episode started in the early 2000s and, like in many Latin American countries, it benefited from a favourable commodities prices cycle that lasted until the mid-2010s. The commodities boom, together with China's growing foreign demand, boosted economic growth across the region. As a consequence, poverty rates in Peru decreased substantially from around 40 per cent in the mid-2000s to 20 per cent in 2018, and inequality only slightly (Herrera 2017). The modest improvement in inequality contrasts the predictions of traditional international trade models that suggest larger distributive welfare gains. This paper aims to identify the structural drivers that shaped Peru's inequality reduction under the scope of two complementary literature strands: international economics and skill-biased technological change (SBTC). The inequality implications of trade liberalization policies have been studied extensively during the last decade and go beyond the traditional (and frictionless) Heckscher-Ohlin-Samuelson (HOS) frameworks, which argue for the equalizing effects of trade liberalization. As Pavcnik (2017) summarizes, such a relationship is context-specific and depends substantially on the ability of workers to move across industries, firms, and locations. As such, better-educated workers will find it less costly to move to alternative sectors and occupations to materialize the potential gains or cope with the risks induced by trade shocks. ${ }^{1}$ This is illustrated by Caselli and Michaels (2013) in Brazil and Loayza and Rigolini (2016) in Peru, who assess the effect of the commodities boom on poverty and inequality and find that mining and oil exploitation activities led to medium- and high-skilled job creation, which could not be fulfilled by the local labour force, which was mostly low-skilled. This, in turn, triggered skilled labour immigration with a consequent rise in inequality. From this perspective, in this paper we assess distributional changes in skills and education levels, factors that are key to the assessment of the equalizing effects of the latest trade liberalization episode in Peru.

The SBTC provides an alternative explanation to the limitations of the traditional HOS framework. The availability of investment capital in a high-skill, labour-intensive sector that opens up to trade may trigger technological changes, thus increasing high-skilled labour demand and relative wages (Pavcnik 2003). The latter implies lower relative wages (and compensation packages) for low-skilled workers, leading to higher inequality. A more nuanced and contemporaneous view suggests that SBTC may shift downward the demand for occupations that could be substituted through automation or outsourced abroad through improvements in communication technologies (Acemoglu and Restrepo 2020). We search for such patterns to diagnose whether this mechanism was a main driver of Peru's modest inequality improvements for the labour force during the last decades.

Alternative channels emphasize the role of labour market imperfections and institutions over the basic theoretical channels linking liberalization episodes to labour market outcomes-that is, labour market deregulation has been suggested to favour pro-poor growth (Besley and Burgess 2004; Botero et al. 2004). In this regard, the Peruvian labour market has been characterized by weak labour market institutions: its informal employment rate-a proxy of compliance with labour regulations-declined only slightly from almost 80 per cent in 2004 to 73 per cent in 2017 (INEI 2018); between 2005 and 2015, minimum wage (MW) interventions were rather moderate as per the cumulated MW growth of about 21 per cent, far from their most active neighbours (i.e. Brazil, Bolivia, and Uruguay, who cumulated 58, 106, and 107 per cent, respectively, during the same period (ILO 2017)). Although institutional factors could have been related to inequality determination, we acknowledge the lack of structural reforms since the mid-2000s and consider that institutional factors stayed relatively constant during the period of analysis.

Our empirical analysis builds on the Peruvian household surveys for 2004-18 (Encuesta Nacional de Hogares (ENAHO)) matched with the skill content of job indicators at the occupational level (ISCO-

\footnotetext{
${ }^{1}$ See Artuc et al. (2015) for an assessment of labour mobility costs in the context of trade policy interventions.
} 
88) obtained from the Programme for the International Assessment of Adult Competencies (PIAAC), published by the OECD. By first implementing a descriptive analysis that unveils potential earningsinequality drivers, we then implement inequality decomposition methods documented by DiNardo et al. (1996) and Fortin et al. (2011). These methods allow the identification of the relative weight of a set of selected inequality drivers. Given the technical difficulties in embedding the determinants of the mining commodities boom into our inequality decomposition, we implement a complementary regression-based method that maps the potential effects of international commodities prices to the many economic sectors through a Leontief (input-output) relationship.

We find evidence of structural shifts in skills, education, and earnings distributions. This is verified by the clear downsizing trends of the more routine low-skilled occupations such as elementary occupations and 'skilled' agriculture and fishery workers, to the benefit of less routine, medium-skilled occupations such as service, shop, and market workers, and plant and machine operators and assemblers, among others. The shift from low- to medium-skilled occupations comes along with an improvement in workers' levels of education. Tertiary-educated workers grew from 24 per cent in 2004 to 34 per cent in 2018. Our decomposition analysis clearly suggests that worker characteristics are less important than unexplained factors (earnings structure) at the lower tail of the earnings distribution, and that the relative importance of workers' characteristics tends to increase as we move into higher quantiles. This may be interpreted as a poverty-trap mechanism that annihilates the potential equalizing effects of education.

Similarly, real earnings grew the most for the lowest paid and more routine occupations. This is particularly the case for the lowest-educated male population, who exhibited the highest earnings growth due to the expansion of the construction sector throughout the period of analysis. Our complementary analysis of the relative importance of the commodities boom shows that its effect is rather negligible as per the Gini index and that the RIF (recentred influence function) decomposition may be considered a reasonable approximation despite its inability to account for the relative weight of the shock.

\section{Inequality trends}

This section analyses trends in inequality over the period $2004-18$ by looking at three main characteristics of the labour force earnings. We begin with an assessment of the distributional changes in real earnings, followed by an analysis of the evolution of returns to education, and trends in real earnings by skill level and by gender. Our population of interest consists of the employed working-age population (15-64 years) and their weekly earnings in Peruvian soles (PEN) of 2009. The data were gathered by Peru's national household survey (ENAHO) through its labour market outcomes module.

\subsection{Real earnings-inequality trends}

Figure 1 (left) presents the (kernel) densities for the log of real earnings from 2004 to 2018 using a colour gradient from light (2004) to dark blue (2018). The colour gradient shows that real earnings increased during the period of analysis, shifting the real earnings distribution to the right. To assess the trends in inequality, Figure 1 (right) shows that the Lorenz curve shifted upwards, signalling an inequality reduction trend between 2004 and 2018.

Similarly, the real earnings decile shares (see Appendix A1) shows that the lowest deciles (below the median) increased their participation in real earnings unambiguously during the period of analysis. Above the median, only the top decile shows a clear reduction of its share from 0.4 to 0.34 between 2004 and 2018. Overall, the improvements in inequality trends are supported by higher real earnings for workers below the median and lesser earnings for workers in the top decile. Alternative inequality indices verify the inequality reduction trends: interquartile ratios increase slightly between 2004 and 2010, and 
decrease sharply afterwards. Gini indices (in log and original scales) exhibit more stability and decrease unambiguously during the period of analysis (Appendix A1).

Figure 1: Log of real earnings: kernel density and Lorenz curve 2004-18
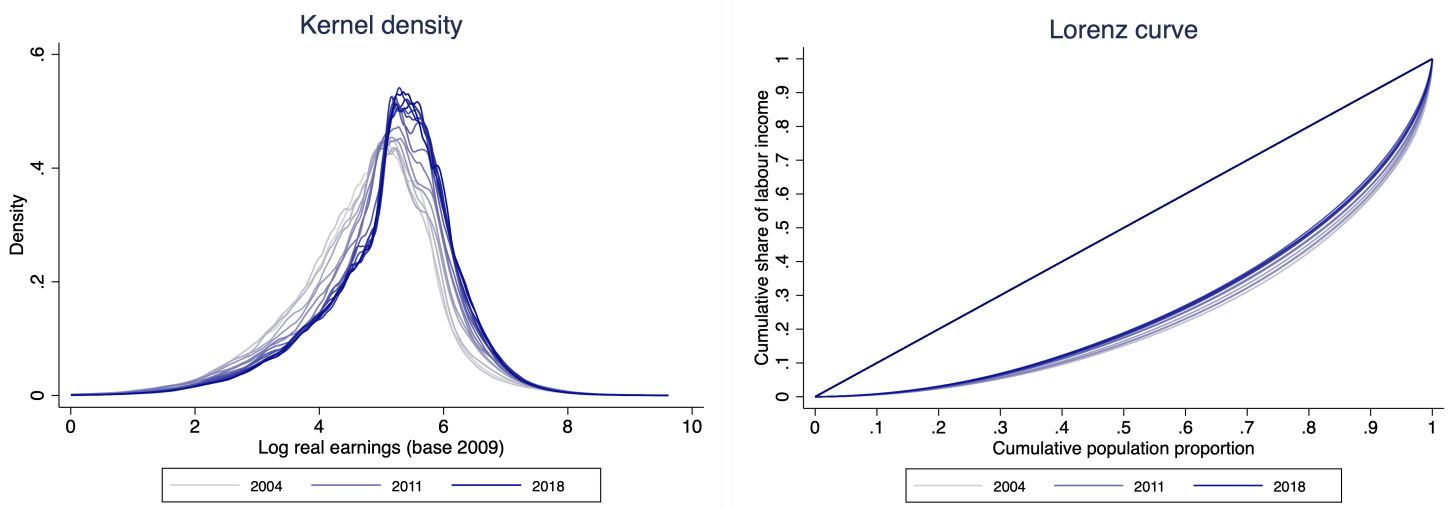

Source: authors' compilation based on data from ENAHO.

The growth incidence curve (Figure 2) for the 2014-18 period (in green) confirm the previous findings; although every real earnings percentile had positive growth, the lowest percentiles grew the most (propoor). Decomposing the period of analysis in two half-periods (2004-11 and 2011-18) reveals that the pro-poor structural changes took place during the 2011-18 period when the lowest percentiles grew at rates above 2 per cent, whereas the highest percentiles (beyond 80) never reached 2 per cent. This verifies the interquartile trends that suggested that inequality improved the most since 2010.

Figure 2: Change in real earnings by percentile, 2004-18

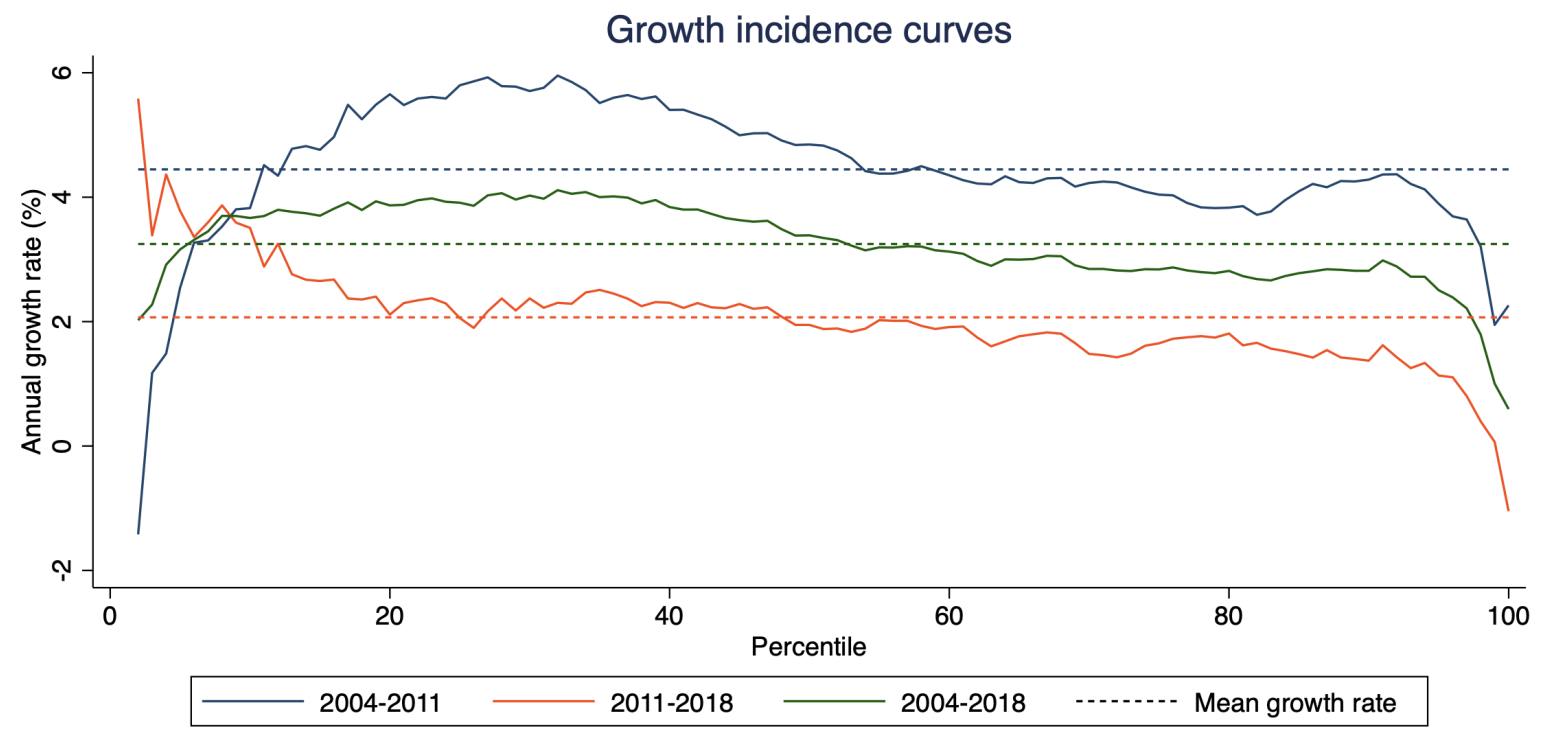

Source: authors' compilation based on data from ENAHO.

\subsection{Change in the education premium on log labour earnings}

The inequality improvement in real earnings may have been caused by structural changes in returns on education and eventually a narrowing of the gender gap. Hence, we estimate the returns on education for the male and female populations, from three alternative econometric specifications applied independently to every cross-section and reported in Appendix A2. The first specification only includes education-level dummy variables where the baseline category is 'no schooling'. In the second specification, workers' characteristics are also included to assess the robustness of the previous estimates. The 
last specification adds occupation-specific effects (ISCO-88, two-digit level). As expected, returns on education are positively related to the level of education across the alternative specifications. Accounting for the occupation-specific effects downsizes the return on education estimates for both genders with respect to the first two specifications. Because it seems to be less vulnerable to omitted variables bias, we interpret the returns on education from the latter specification. Figure 3 (upper panel) plots the coefficients for education-level dummy variables (primary, secondary, and tertiary) that are to be interpreted as returns on education with respect to no schooling, whereas the lower panel illustrates gender-specific intercepts at different education levels, which show the dynamics of the education-specific wage gender gap.

Figure 3: Returns on education with respect to no schooling and gender gap

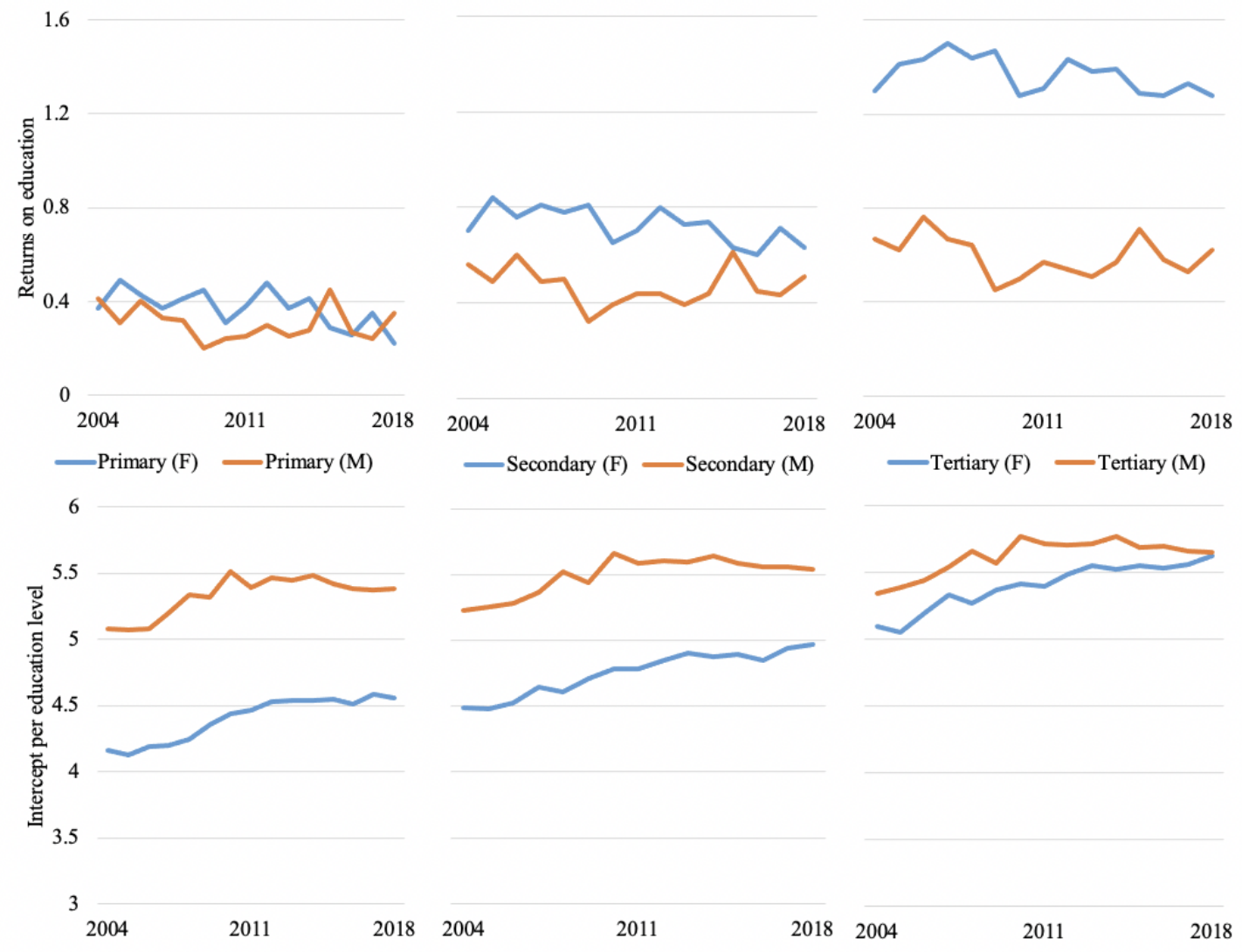

Source: authors' compilation based on data from ENAHO.

Primary education. Returns on primary education (upper panel) show a slight downward trend for both men and women, where both exhibit similar primary education premia. The implied gender gap illustrated in the lower panel stays relatively constant, although both average wages increased slightly over time.

Secondary education. Returns on secondary education stay relatively constant during the period of analysis, although one can clearly see that women's secondary education premia stayed at higher levels. As a consequence, the wage gender gap narrows between 2004 and 2018.

Tertiary education. Returns on tertiary education are relatively constant across time, but have been favouring women since 2004. This has had positive implications for the wage gender gap, which has narrowed the most during the period of analysis.

These figures suggest that education premia could have played a role in inequality reduction as long as the female labour force had shifted to higher educational levels during our period of analysis. The employment distribution by education level (Table 1) shows a regular trend towards a better-educated 
labour force in 2018. The share of workers with tertiary education increases unambiguously, while loweducation categories (no schooling and primary education) decrease for men and women. The systematic improvement in women's education and the narrowing of the wage gender gap at the highest levels of education is likely to have contributed to inequality reduction.

\begin{tabular}{|c|c|c|c|c|}
\hline & 2004 & 2011 & 2018 & Average \\
\hline \multicolumn{5}{|l|}{ Men's education } \\
\hline No schooling & 1.89 & 1.30 & 0.87 & 1.31 \\
\hline Primary & 25.97 & 20.56 & 17.55 & 21.05 \\
\hline Secondary & 47.00 & 46.88 & 47.90 & 47.29 \\
\hline Tertiary & 25.14 & 31.26 & 33.68 & 30.34 \\
\hline Total & 100.00 & 100.00 & 100.00 & 100.00 \\
\hline \multicolumn{5}{|c|}{ Women's education } \\
\hline No schooling & 9.18 & 5.59 & 3.91 & 5.99 \\
\hline Primary & 30.23 & 25.19 & 23.01 & 25.81 \\
\hline Secondary & 37.25 & 37.28 & 38.37 & 37.68 \\
\hline Tertiary & 23.34 & 31.95 & 34.70 & 30.52 \\
\hline Total & 100.00 & 100.00 & 100.00 & 100.00 \\
\hline
\end{tabular}

Source: authors' compilation based on data from ENAHO.

To account for the changes in labour force characteristics on the overall effect on real earnings growth we estimated the predicted real earnings for the labour force sample and calculated its cumulated growth since 2004. Figure 4 shows that while women's earnings grew homogeneously by almost 50 per cent since 2004 irrespective of the level of education, men's earnings grew the most for the least educated in the labour force (almost 80 per cent by 2018), whereas the better educated (tertiary) earnings grew up to 40 per cent by 2018 . This suggest that the inequality improvements are likely to be explained by the narrowing of the earnings gap between tertiary-educated workers and those with no education in male-dominated occupations.

Figure 4: Real weekly earnings (fitted) by gender and education level (2009 PEN)

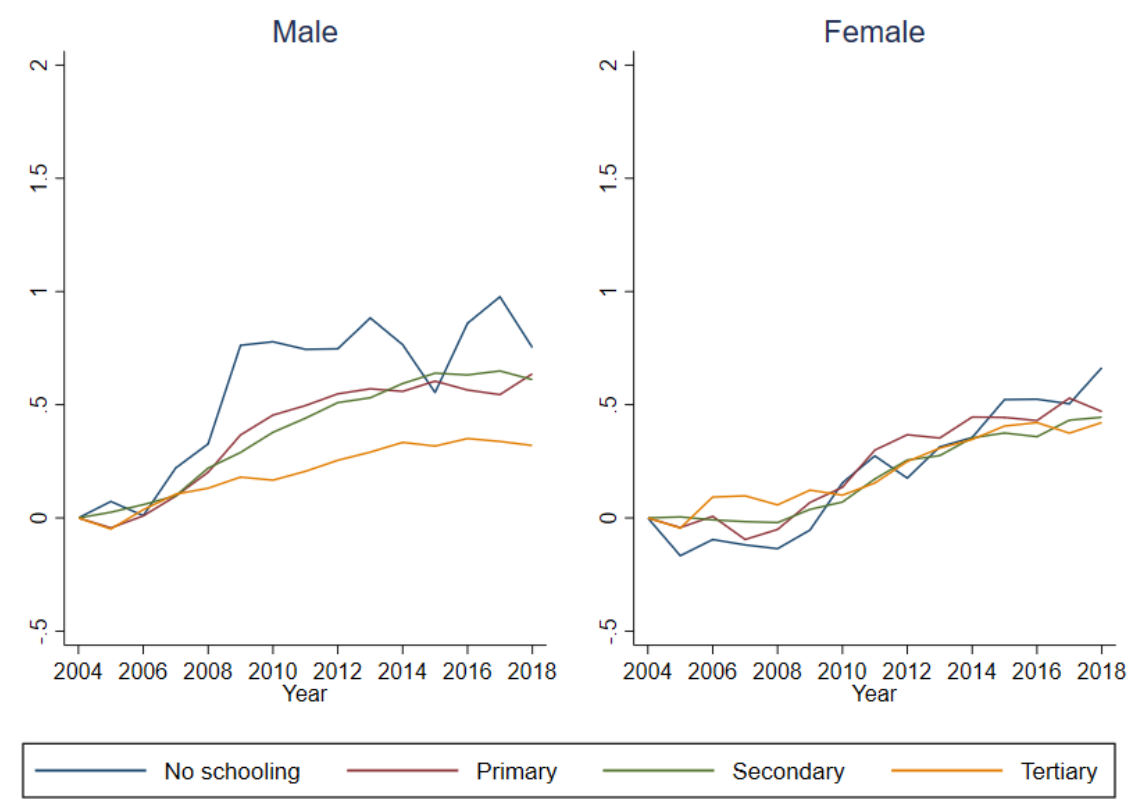

Source: authors' compilation based on data from ENAHO.

Trends in real earnings by skill level and gender

The previous figures indicate that inequality improvements were associated with higher earnings growth for the lowest-educated male population. To better understand the channels driving such growth, we now 
identify the specific occupations that concentrate workers of different education levels. We identify low-, medium-, and high-skill worker categories based on Peru's statistical office assessment (INEI 2015). Figure A1 in the Appendix supports our classification of occupations into high-, medium-, and lowskilled as it presents the boxplot distribution of the average years of education for different occupations (ISCO-88, one-digit level) sorted on the horizontal axis by their real earnings historical mean.

Low skilled. Workers in ISCO-88 categories 6 (skilled agricultural and fishery workers) and 9 (elementary workers) are the least educated and receive the lowest average earnings. Figure 5 confirms the previous findings as male workers' earnings for these occupations (left) grew above those of their female counterparts (right). While male workers' cumulated growth at 2018 ranges between 60 and 80 per cent, female workers' earnings cumulated growth ranges between 30 and 60 per cent

Figure 5: Cumulated earnings growth (2004-18), low-skill occupations
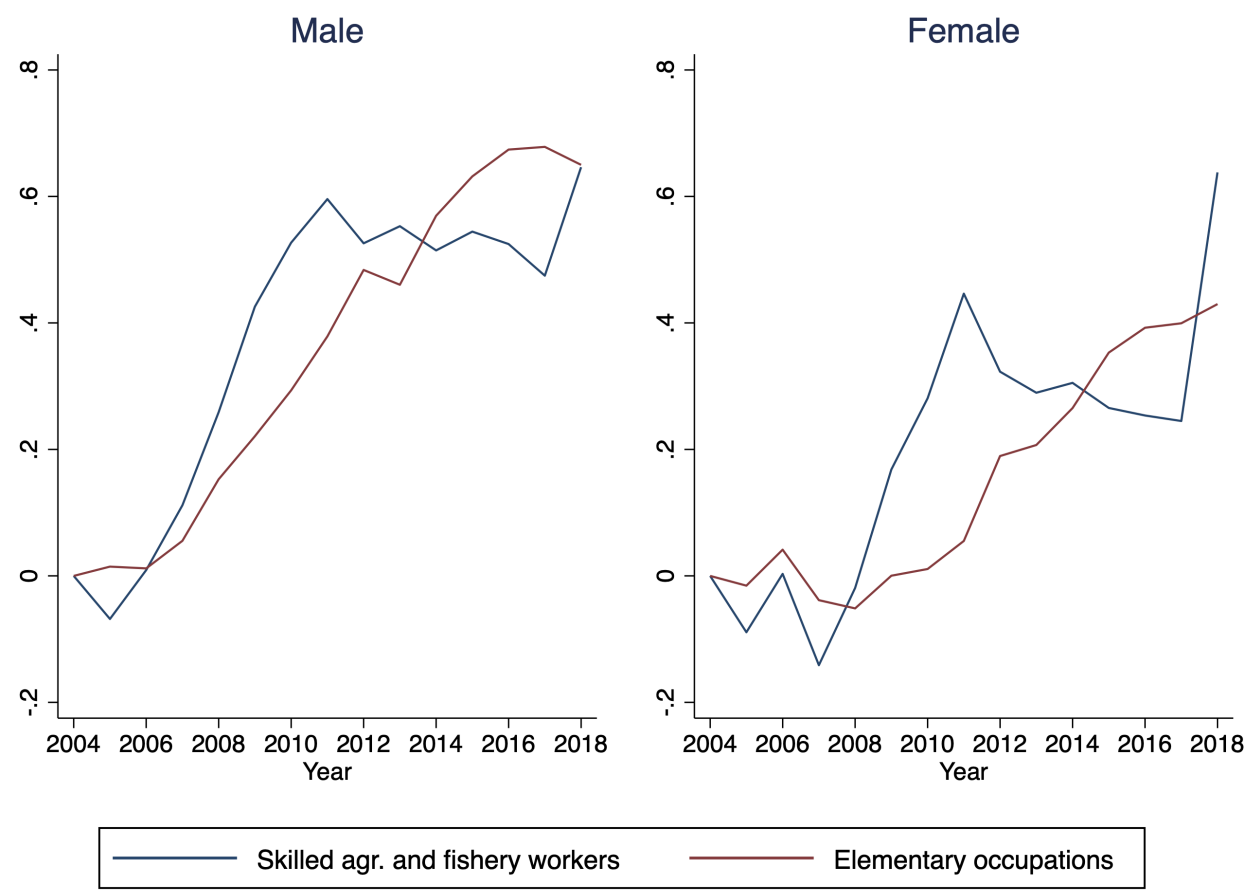

Source: authors' compilation based on data from ENAHO.

High skilled. Occupations 1 (legislators, senior officials, and managers), 2 (professionals), and 3 (technicians and associated professionals) earn the most and demand workers with the highest education levels (more than 12 years on average). Male and female cumulated earnings trends show similar behaviour, except for legislators, senior officials, and managers, for which women's earnings grew the most (Figure $6)$.

Medium skilled. Workers in ISCO-88 categories 5 (service, shop, and market workers), 7 (craft and related trade workers), and 8 (plant and machine operators and assemblers) can be classified as medium skilled as per their middle earnings and average years of education. Even though workers employed at ISCO 4 and 3 exhibit similar average education levels, the former requires lesser qualifications than the latter according to Peru's statistical office INEI (2015). ISCO-88 category 4 is then considered as a medium-skilled occupational group and the seemingly high education level of its workers would be a consequence of an excess of labour supply of highly educated individuals who must take jobs for which they are overqualified. Earnings cumulated growth exhibits similar trends for both genders (Figure 7). 
Figure 6: Cumulated earnings growth (2004-18), high-skill occupations
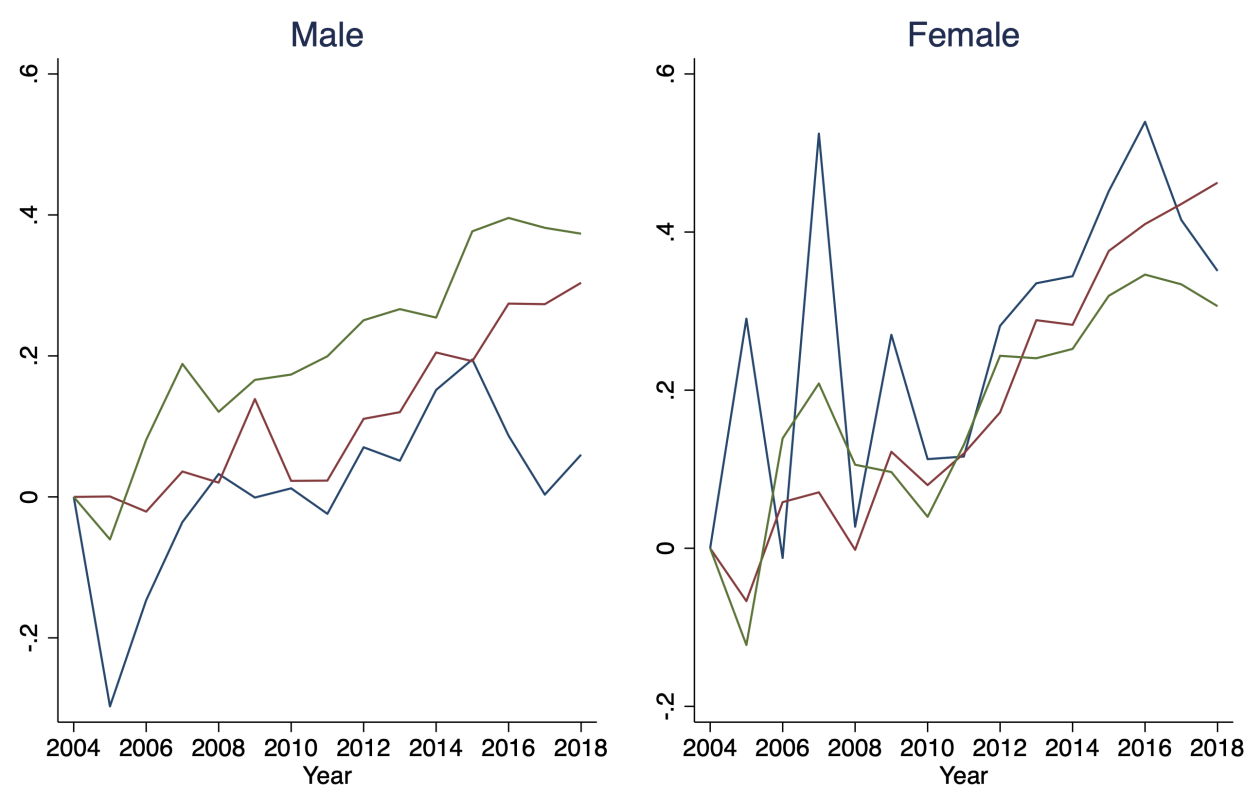

Legislators \& Managers

Professionals

Tech. and asocc. professionals

Source: authors' compilation based on data from ENAHO.

Figure 7: Cumulated earnings growth (2004-18), medium-skill occupations
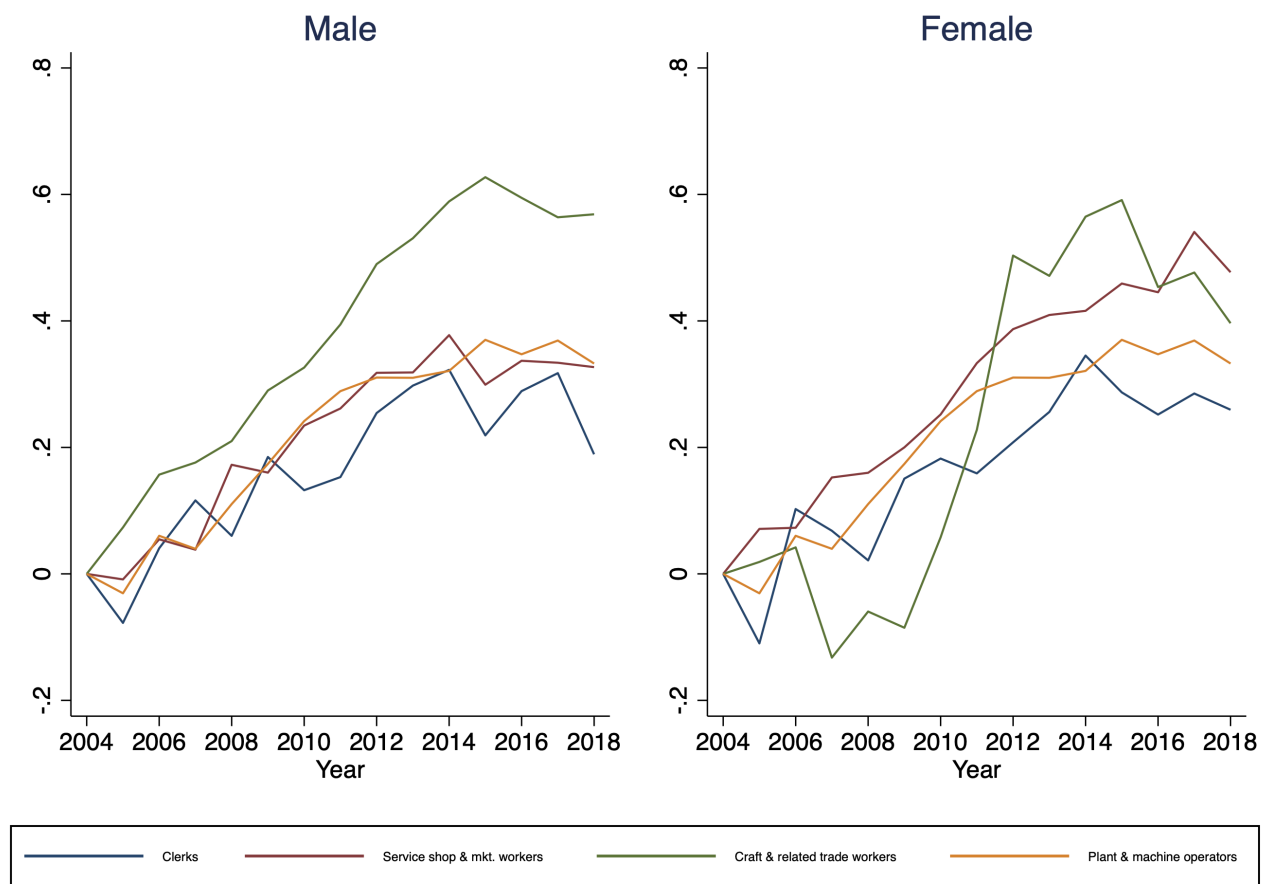

Source: authors' compilation based on data from ENAHO.

The descriptive analysis of real weekly earnings showed an improvement in inequality indicators that correlate with an increase in earnings for the least-educated males employed in low-skill occupations (agriculture, fishery, and elementary occupations). We now explore distributional changes in employment as an alternative driver of the inequality trends during the period of analysis. 


\subsection{Distributional changes in employment}

In accordance with the above-mentioned educational profile trends, low-skill occupations (elementary occupations and skilled agriculture) systematically reduced their employment share between 2004 and 2018 (Figure 8). Interestingly, for women their share in elementary occupations diminished from 50 to 40 per cent, while their participation as service, shop, and market workers (medium skilled) increased from 20 to 27 per cent in the period of analysis (Figure 8, right). For men we see a less clear distributional shift from elementary occupations to various medium-skilled occupations; we therefore aggregate occupations according to skill levels to identify an underlying pattern.

Figure 8: Employment distribution by occupation: male (left) and female (right)
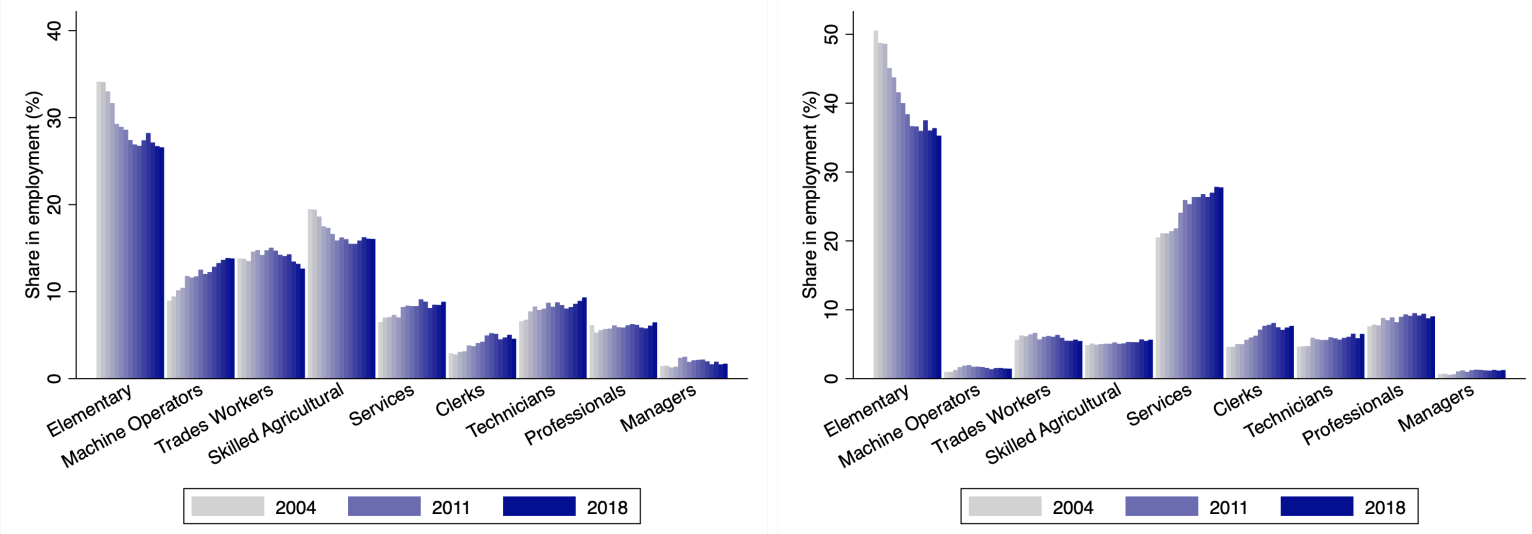

Source: authors' compilation based on data from ENAHO.

Merging the ISCO-88 (occupations) into skill levels provides a clearer picture of the structural changes in labour force skills distribution. Figure 9 shows that the distribution of labour force skills improved due to a shift from low- to medium-skilled occupations, irrespective of gender. The 'shift' could be attributed to job-to-job transitions or to inflows from new entrants to the labour force.

Figure 9: Employment distribution by skill level: male (left) and female (right)
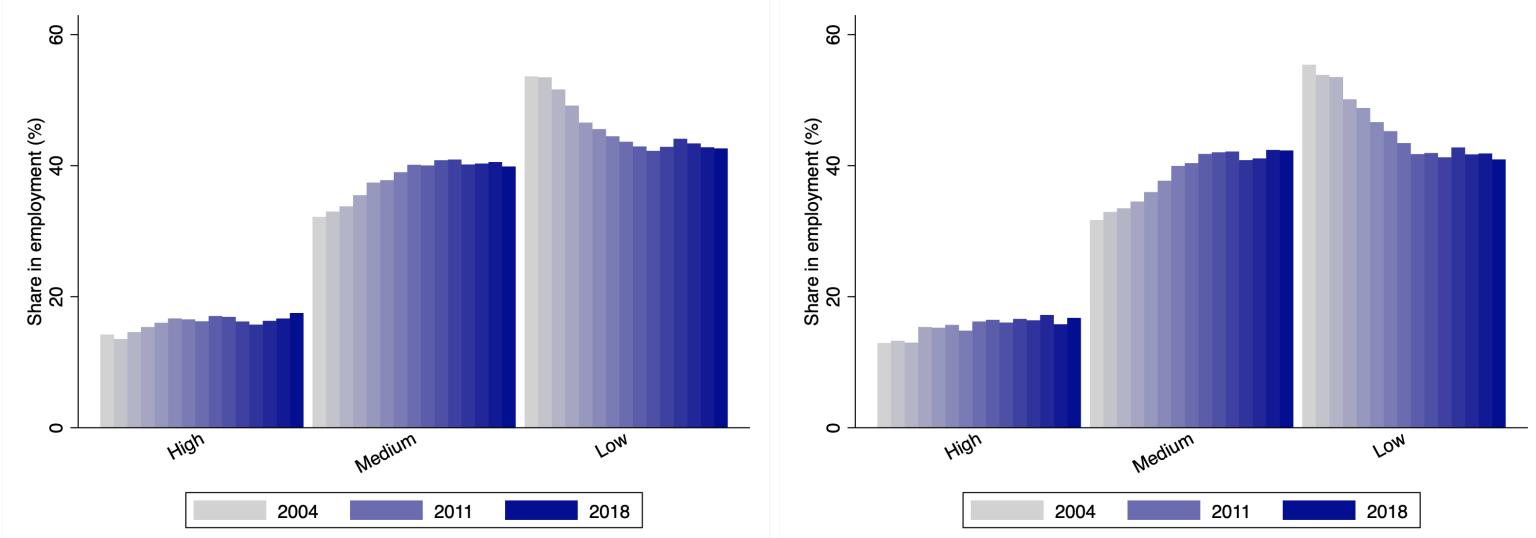

Source: authors' compilation based on data from ENAHO.

A look into the employment distribution across economic sectors (Figure 10) confirms the previous trends as the employment share in agriculture - fundamentally low skilled-has decreased for both men and women. Conversely, employment in the services sector (medium skilled) has increased steadily. The expansion in the construction sector during the period of analysis explains the rise in its employment share. Since it's a sector rather intensive in low-skilled employment, the labour demand expansion is likely to partly explain the earnings growth of the least-educated male labour force (Figure 4). 
Figure 10: Employment distribution by economic branch: male (left) and female (right)
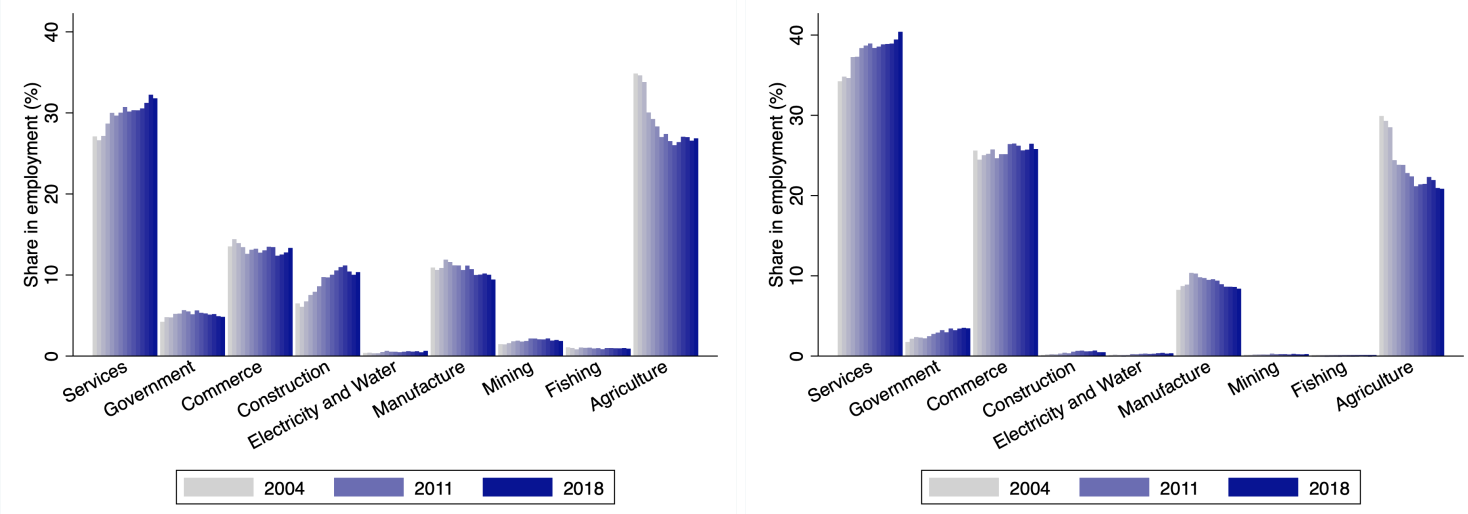

Source: authors' compilation based on data from ENAHO.

\subsection{Changes in employment distribution and earnings by skill percentiles}

Inequality reduction requires that the least favoured segments of the labour force receive the greatest improvement. We look for such reallocation patterns by relating the changes in occupational employment shares between 2004, 2011, and 2018 (vertical axis) to occupations ranked by their mean earnings in the baseline period, either 2004 or 2011 (Figure 11, left). We notice that lower-paid (in 2004) occupations (such as 61, 92, 74, and 91) reduced their employment share between 2004 and 2011. These occupations are mainly classified as low skilled $(61,91,92)$. In contrast, average-paid occupations $(83,51,52$, among others) and high-paid occupations increased their employment share, with the former doing so by more than the latter. These changes would partly explain the inequality reduction from 2004 to 2011 . Changes in employment shares between 2011 and 2018 exhibit a similar pattern as poorer occupations reduced their employment shares the most. With regards to changes in earnings distribution, Figure 11 (right) illustrates another equalizing pattern between 2004 and 2011 as lower- and middle-paid occupations experience the highest increase in earnings, while the better-paid occupations improved their earnings to a lesser extent. During 2011-18, earnings changed homogeneously across occupations irrespective of their baseline (2011) mean earnings. Overall, the 2004-18 occupational changes in employment and earnings seem to be dominated by shifts during the 2004-11 period.

As a robustness check, we group the ISCO-88 (two-digit level) occupations into 'skill' quintiles, where skills are proxied by the occupational weighted average earnings. ${ }^{2}$ The upper panel of Figure 12 argues for a positive relationship between the occupational employment share growth and mean earnings, whereas the lower panel indicates a slight negative relationship between earnings growth and skill level. Both relationships point to an improvement in inequality since the most vulnerable (the lower paid) decreased their employment share while increasing their earnings.

\footnotetext{
${ }^{2}$ Weights are given the occupational employment with respect to the employed labour force
} 
Figure 11: Changes in employment share (left) and earnings (right) by occupation (ranked by earnings in 2004)

Changes in employment

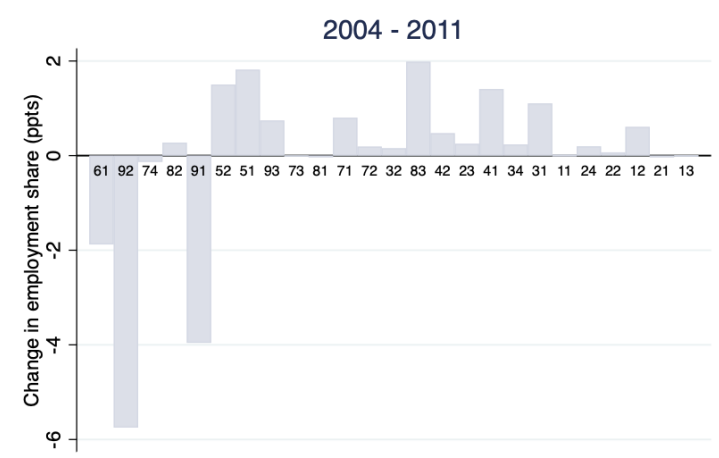

$2011-2018$

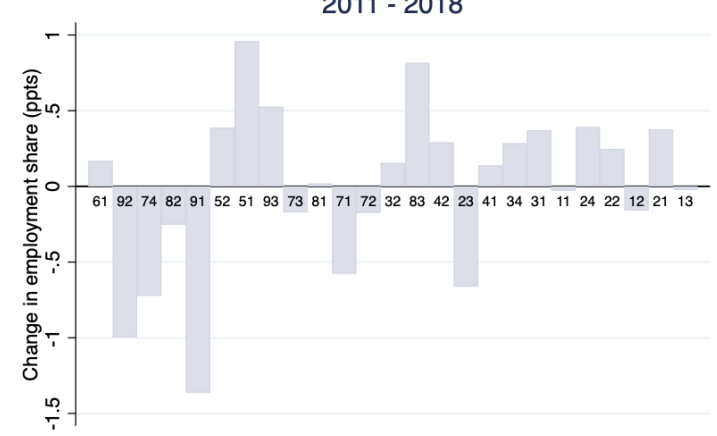

$2004-2018$

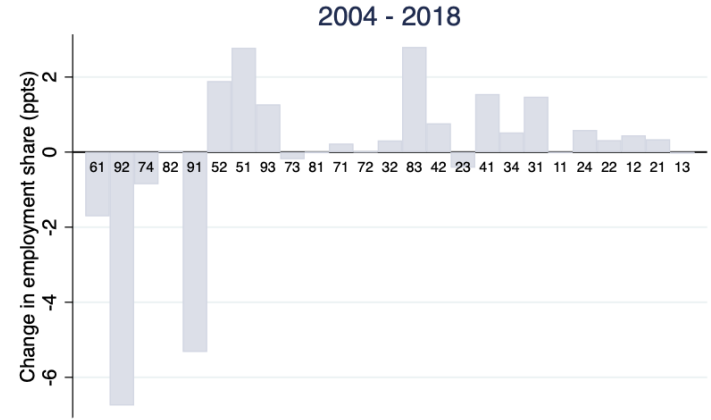

Occupations (ISCO-88) ranked by mean log earnings
Changes in log earnings

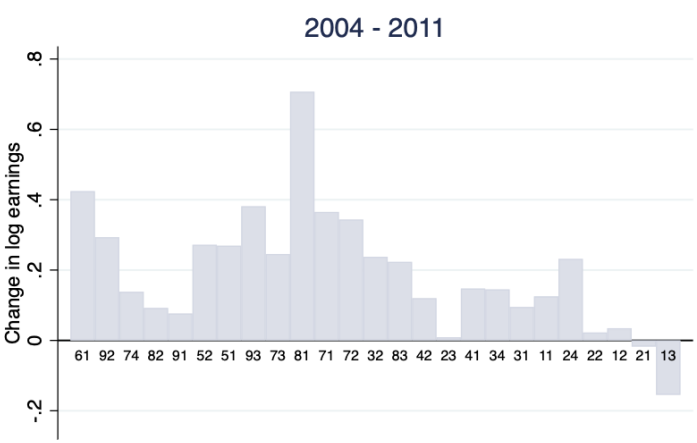

$2011-2018$

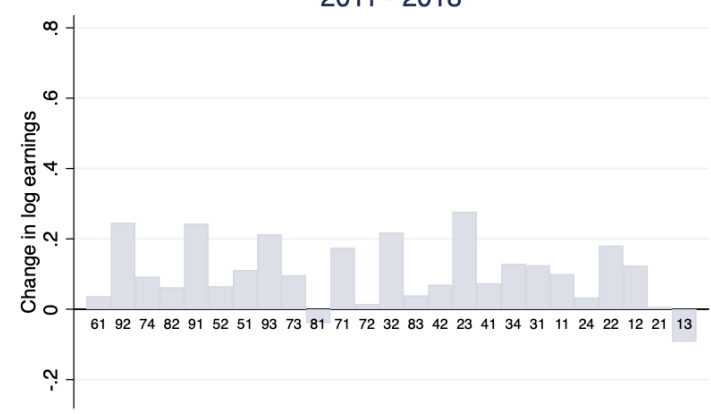

$2004-2018$

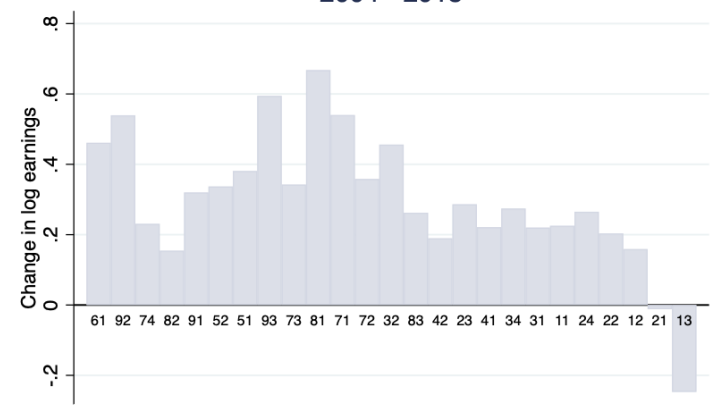

Occupations (ISCO-88) ranked by mean log earnings in each graph

Source: authors' compilation based on data from ENAHO. 
Figure 12: Changes in employment shares (upper) and earnings (lower) by skill quintiles (2004)
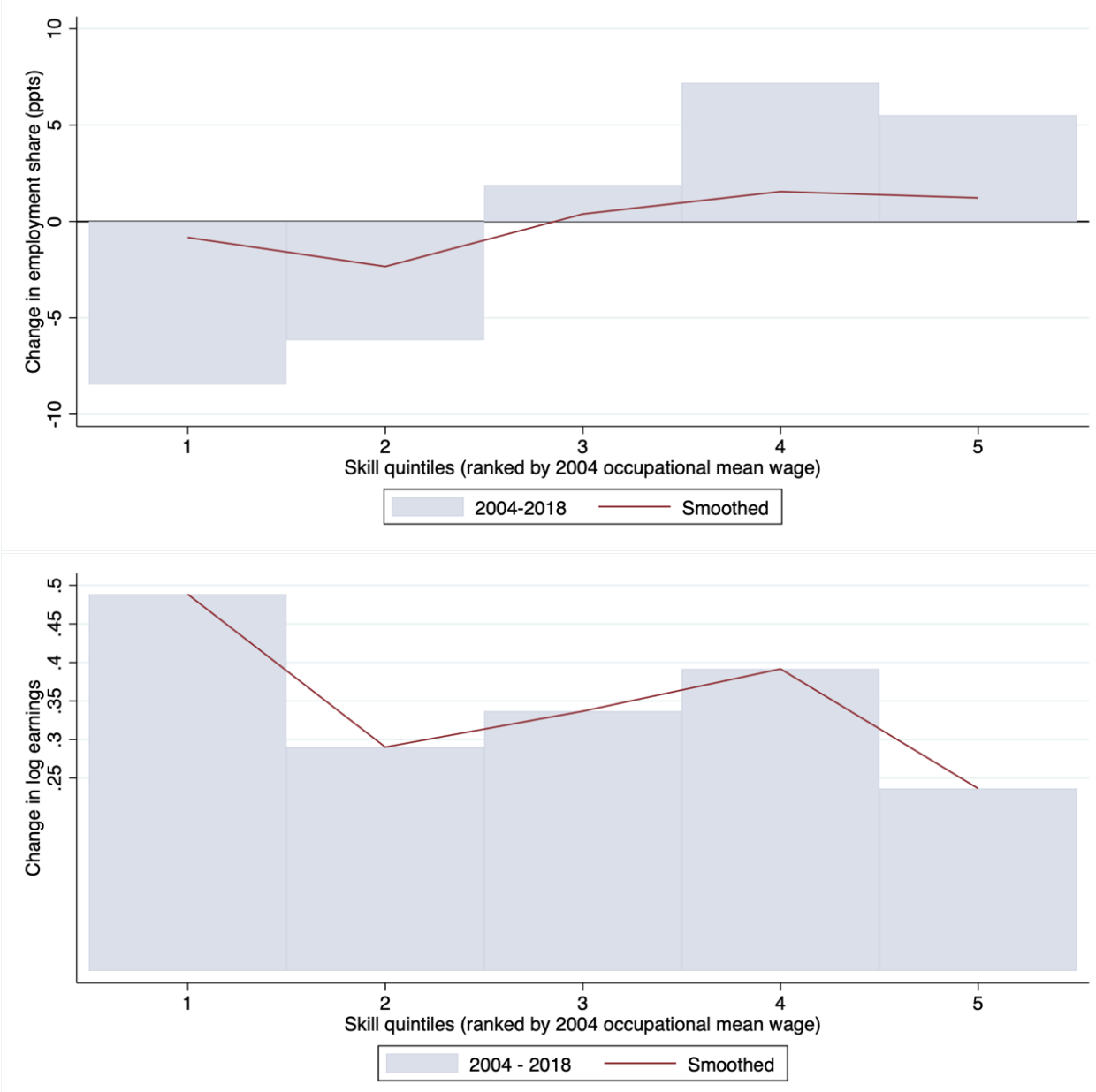

Source: authors' compilation based on data from ENAHO.

The following regression formally tests for this apparent negative relationship between changes in occupational employment and earnings. We follow Autor and Dorn (2013) and estimate the model:

$$
d \ln E_{j t}=\gamma d \ln R_{j t}+u_{j t}
$$

where $\gamma$ is the elasticity that relates the employment $\left(E_{j t}\right)$ and earnings $\left(R_{j t}\right)$ change per occupation (ISCO-88, two-digit level) at a given point in time (t). To identify this elasticity, the equation is estimated by OLS (ordinary least squares) for three periods of analysis: 2004-11, 2011-18, and 2004-18, where the dependent variable is the change in the log of the occupational employment share and the explanatory variable is the change in the log of the mean real earnings for a given occupation. Note that the $\gamma$ parameter has no causal interpretation, being only a correlation measure. Appendix A3 presents the elasticities for each sub-period. We verify a negative but non-significant elasticity parameter $(-0.268)$ for 2004-11, in line with Figure 12 trends. Still in line with the Figure 12 findings, this elasticity fades (0.12) in 2011-18.

To go beyond the relationship between occupation and earnings changes, we now test for the presence of polarization effects. This is motivated by the fact that in developed economies the SBTC explains the increasing inequality effects that result from technological change through polarization. Polarization is described as an increase in employment shares at both tails of the occupational earnings distribution. The previous figures do not suggest its presence, so we formally analyse them through regression analysis. 


\section{Employment and earnings polarization}

To formally test for these effects we follow Goos and Manning (2007) and estimate the quadratic relationship:

$$
\Delta \ln E_{j t}=\beta_{0}+\beta_{k} \ln R_{j t-1}+\theta \ln ^{2} R_{j t-1}+u_{j t}
$$

We estimate this model for our two periods of analysis (2004-11 and 2011-18) and for 2004-18. Overall, our 2004-18 estimates (see Table A11) do not provide statistical evidence of polarization. Only the 2004-11 employment polarization specification unveils some statistically significant patterns, suggesting that this period was characterized by inequality improvements- that is, employment shares diminished and earnings increased for the poorer and richer occupations. No polarization effects are detected during the 2011-18 sub-period. The absence of polarization effects is in line with our visual inspection of Figure 11 (left).

To further check for this relationship, we estimate the previous model with the log of real earnings as the dependent variable. As with the employment polarization tests, there is no evidence of polarization in earnings (see Table A11).

Our results confirm Herrera's (2017) polarization analysis for household consumption expenditure and income over the 2004-15 period, using the Foster and Wolfson (2010) polarization index. Furthermore, Maloney and Molina (2016) and Messina and Silva (2017) provide similar conclusions regarding the absence of employment polarization effects in many Latin American countries (Brazil, Peru, and Mexico). It is argued that forces other than technological change, such as commodities boom spillover effects or labour supply elasticities, may have taken a leading role in the determination of labour force dynamics.

\subsection{Distributional changes and routine task content of occupations}

Technological change is expected to increase the marginal productivity of non-routine occupations that require cognitive skills, while it can also displace workers from occupations that are intensive in routine tasks through automation or by outsourcing of those tasks abroad. Hence, focusing on the routine task content of occupations rather than its 'skills' may eventually lead to an alternative assessment of SBTC inequality effects in the Peruvian context.

Three alternative measures for the routine task content of ISCO-88 (two-digit level) occupations were available for our analysis. These are (1) the US O*NET statistics; (2) the US PIAAC survey gathered from Lewandowski et al. (2020); and (3) Peru's country-specific PIAAC survey. As can be seen in Figure 13, the occupational routine task intensities (RTIs) exhibit similar rankings across definitions, except for agricultural and fishery workers (code 6, ISCO-88, one-digit level). According to Peru's PIAAC survey, this occupation is ranked as having the second highest RTI among the nine (one-digit) ISCO-88 occupations, whereas the O*NET RTI ranks it fourth. Similarly, ranking the ISCO-88 (one-digit level) occupations by their historical mean incomes and by years of education shows that this occupation has the lowest historical mean in earnings and in years of education, which is best proxied by the PIAAC RTI ranking (see Figure A1). Due to the similarity between options (2) and (3), the forthcoming analysis presents some robustness checks based on both O*NET (1) and PIAAC (3) RTIs only. 
Figure 13: Alternative RTI indicators

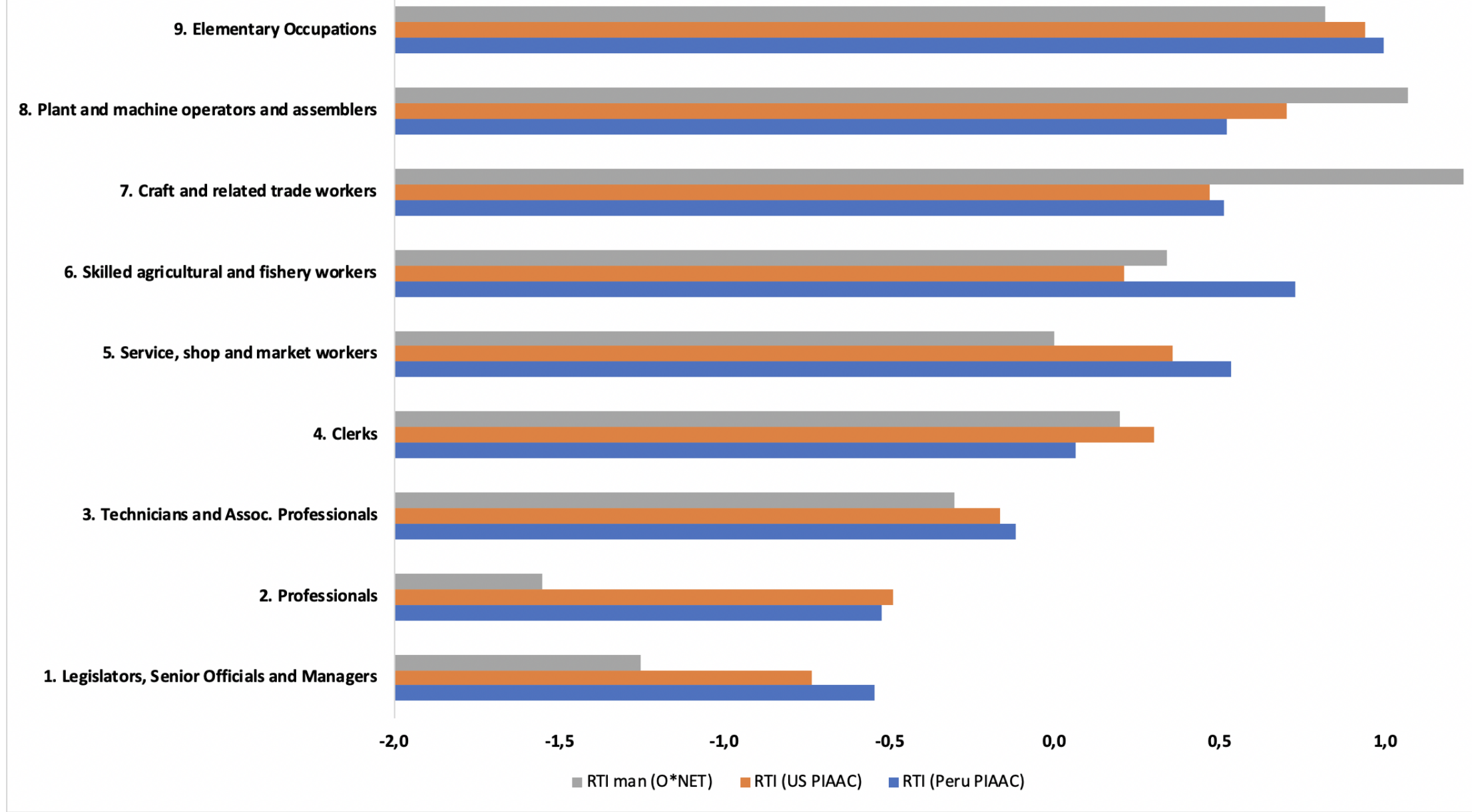

Source: authors' compilation based on data from ENAHO. 
Since the raw RTI indicators at two- or three-digit breakdowns are time invariant (they are only observed for a given year), the aggregated RTIs trends are determined by shifts in the distribution of occupations. The average RTI indicators (Figure 14) exhibit an unambiguous downward trend until 2011-12 and stay relatively constant up to 2018, which suggests the presence of structural changes in the distribution of occupations during the first period of our analysis (2004-11).

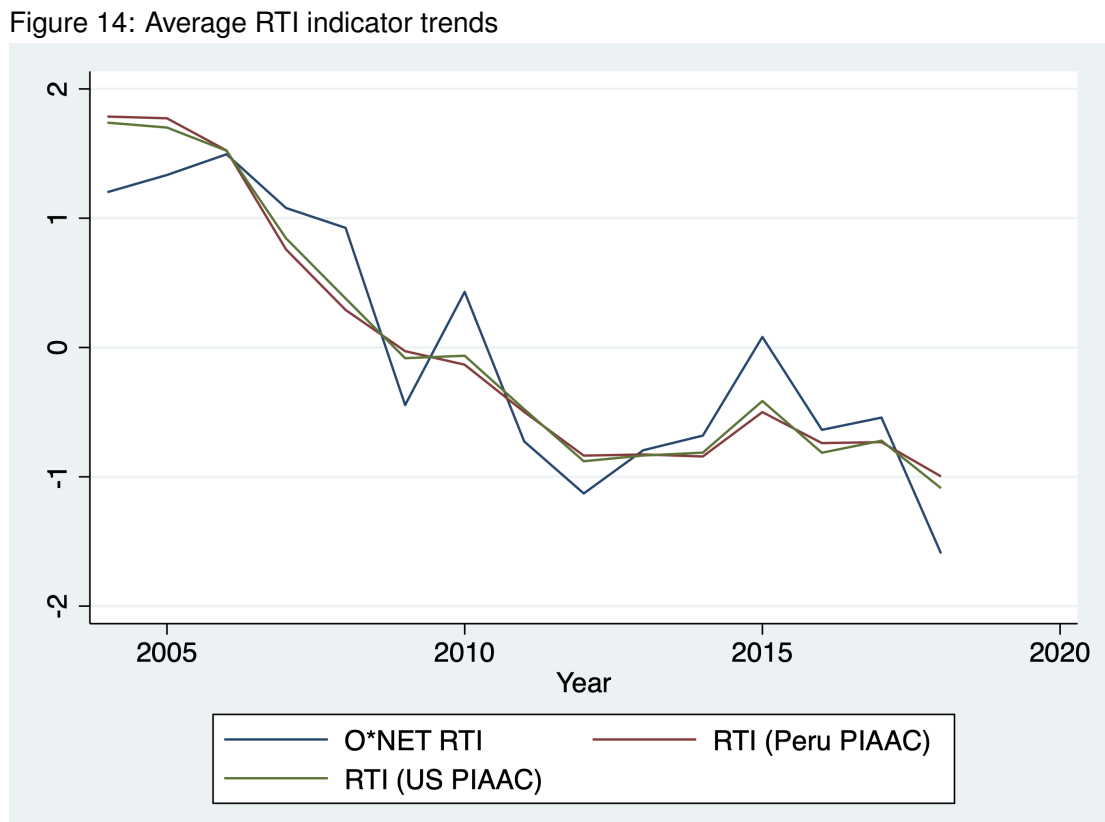

Note: the average RTIs have been normalized (by their historical mean and standard deviations) for comparability purposes. Source: authors' compilation based on data from ENAHO.

To illustrate the importance of analysing RTIs instead of 'skills', we plot both variables in Figure 15. We observe that skills (proxied by earnings) are negatively related to the routine task content of occupations, yet this relationship is not globally linear but flat up to the sixth decile. This implies that under the more nuanced (RTI-based) SBTC view, low-skilled workers (those placed below the sixth decile) are homogeneous on their RTIs and are therefore expected to be similarly affected by technological change, and not so for those placed above the sixth decile.

Figure 16 (left) relates the occupational employment changes between 2004-11, 2011-18, and 2004-18 to the ISCO-88 (two-digit level) occupations, presented in descending order of their PIAAC RTI (on the horizontal axis). Elementary occupations $(92,91)$ characterized by their high RTI, are those that reduced their employment share the most. In contrast, occupations with mid-valued RTIs and low RTIs increased their employment shares, with the mid-valued ones increasing more than low-valued ones. This pattern supports our skill reallocation findings, as there seems to be an employment shift from highly routine occupations to moderately routine ones. Earnings evolution with respect to occupations' RTIs seem to exhibit a slight relationship where high RTI occupations increased their earnings the most during 200411 (Figure 16, right). Interestingly, contrary to a traditional 'skills' view (Figure 11), the RTI (PIAAC) approach suggests the presence of inequality improvements in occupational employment changes even after 2011.

Like in the skill-based analysis, we infer that improvements in inequality could be attributed to employment shifts from routine to less routine (better paid) occupations. Breaking down these variations into our two sub-periods of analysis confirms that most of the employment and earning changes occurred during the 2004-11 period (Figure 16, upper and middle panels). 


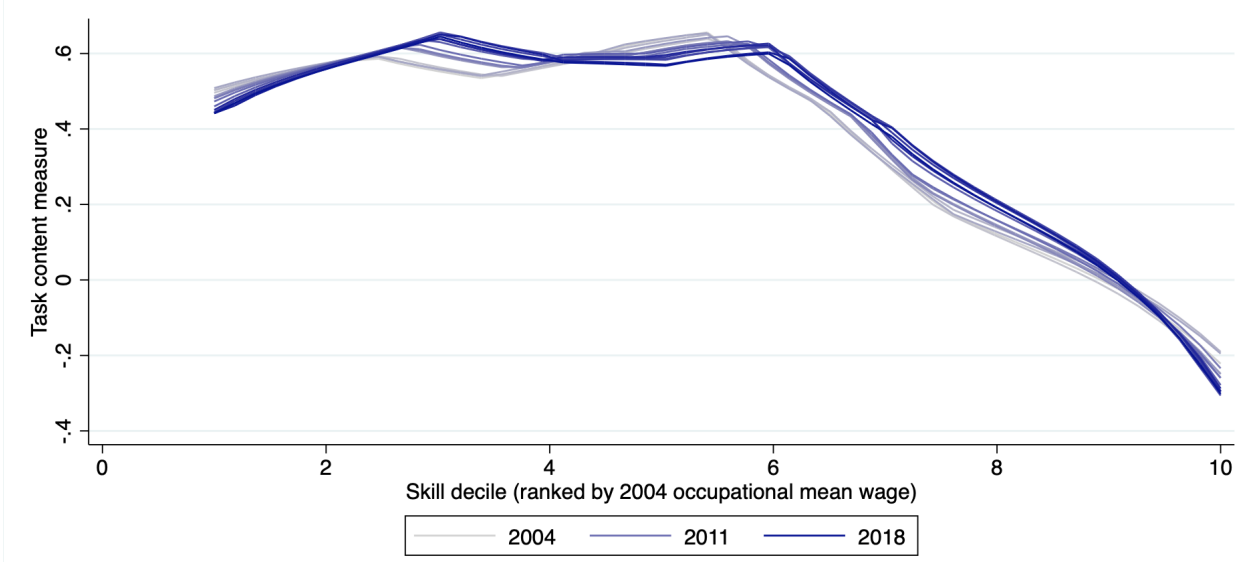

Note: the gradient of colours from light to dark blue represent the RTI trend from 2004 to 2018.

Source: authors' compilation based on data from ENAHO.

Performing the previous analysis and building on the O*NET RTI (see Figure 17) as a robustness check yields similar results regarding the changes in (log) earnings. In contrast, changes in employment seem not to be improving inequality as they are not concentrated in the most routine occupations as was the case with the RTI (PIAAC). This is explained by the heterogeneity of Peru's country-specific RTI (PIAAC) and the $\mathrm{O}^{*}$ NET alternative indicator for occupations 91 and 92. Since the country-specific RTI exhibits a more coherent correlation with historical educational and earnings levels, we consider it our preferred RTI classification.

A formal assessment of the potential polarization effects is provided by a regression analysis that accounts for the specific weight of each occupation in the employed labour force (Sebastian 2018). The regression analysis relates the change in the employment share at a given occupation and its baseline RTI (PIAAC) (Table 2). We do not find evidence of polarization (statistically significantly negative and positive linear and quadratic sign on the RTI) for any period of analysis under the country-specific RTI (PIAAC) definition. The regression on the change in (log) earnings with respect to the RTI (PIAAC) verifies the absence of polarization. Performing the same regression analysis based on the O*NET RTI yields the same results (see Table A12).

Table 2: Change in earnings and employment (RTI PIAAC)

\begin{tabular}{lcccccccc}
\hline & \multicolumn{3}{c}{ Change in empl. share } & & \multicolumn{3}{c}{ Change in log earnings } \\
\cline { 2 - 3 } \cline { 8 - 9 } & $2004-11$ & $2011-18$ & $2004-18$ & & $2004-11$ & $2011-18$ & $2004-18$ \\
\hline Baseline RTI (PIAAC) & -0.580 & -1.416 & 185.823 & & -1.941 & 0.719 & 153.206 \\
& $(1.468)$ & $(0.998)$ & $(116.795)$ & & $(1.174)$ & $(0.746)$ & $(121.081)$ \\
Baseline RTI (PIAAC) squared & -0.283 & -0.682 & $-312.067^{* *}$ & & -0.708 & -0.862 & -108.773 \\
& $(1.504)$ & $(0.914)$ & $(114.669)$ & & $(1.251)$ & $(0.854)$ & $(141.707)$ \\
Constant & 0.518 & 1.039 & 60.172 & & $1.399^{*}$ & -0.236 & -21.839 \\
& $(0.940)$ & $(0.688)$ & $(47.203)$ & & $(0.689)$ & & $(0.474)$ & $(79.280)$ \\
\hline Observations & 25 & 25 & 25 & & 25 & 25 & 25 \\
R-squared & 0.022 & 0.217 & 0.166 & & 0.288 & & 0.030 & 0.033 \\
\hline
\end{tabular}

Note: clustered standard errors in parentheses. Clustered at the ISCO-88 two-digit level. ${ }^{*} p<0.1,{ }^{* *} p<0.05,{ }^{* * *} p<0.01$. Source: authors' compilation based on data from ENAHO. 
Figure 16: Changes in employment shares and earnings by occupation (ranked by their PIAAC RTI)

Changes in employment
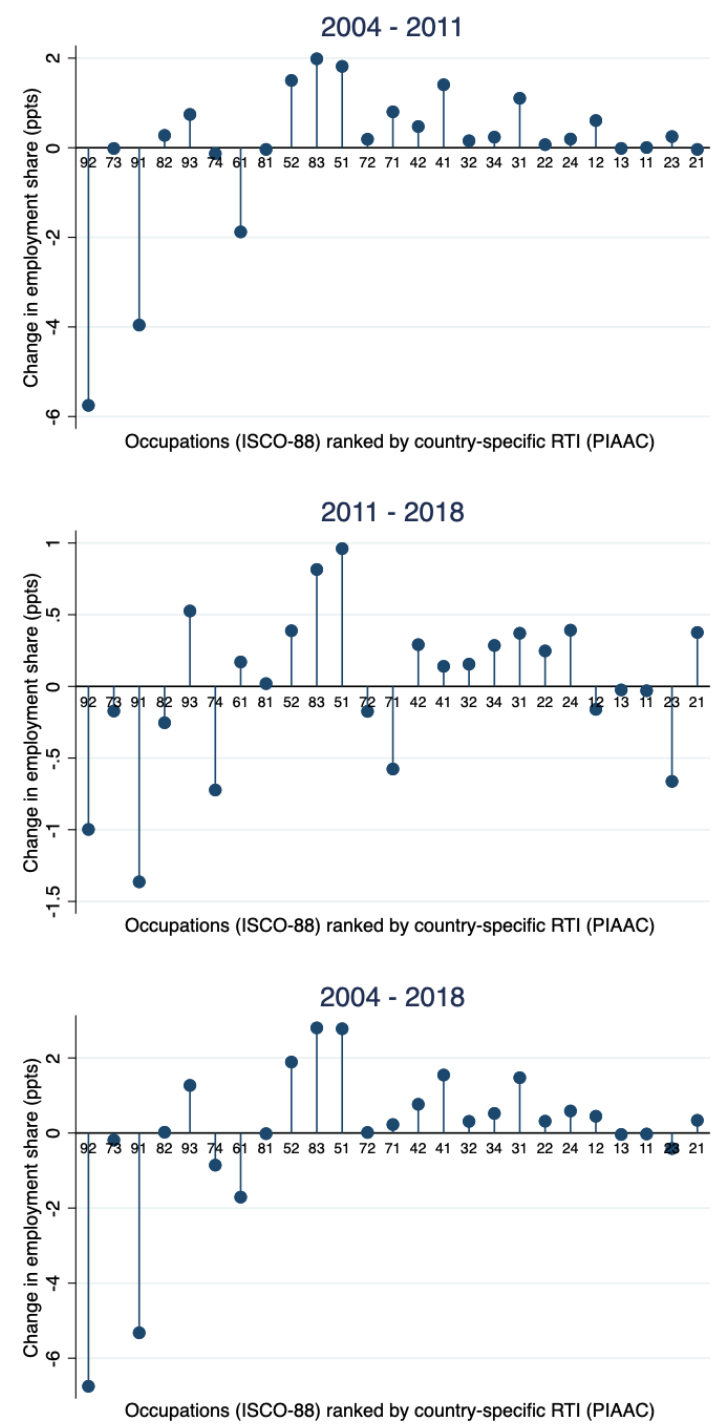

Source: authors' compilation based on data from ENAHO.
Changes in log earnings

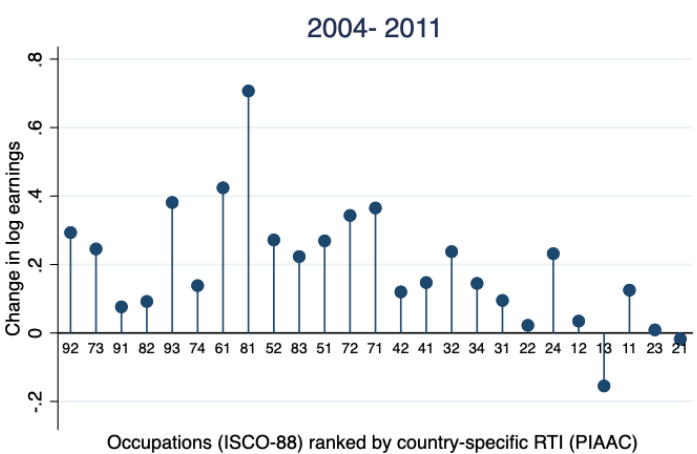

$2011-2018$

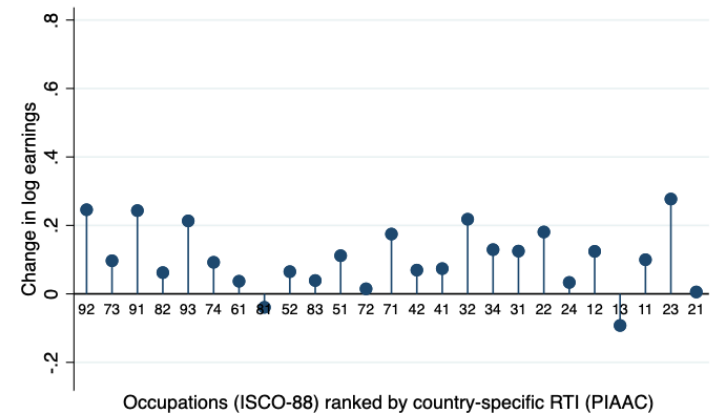

2004 - 2018

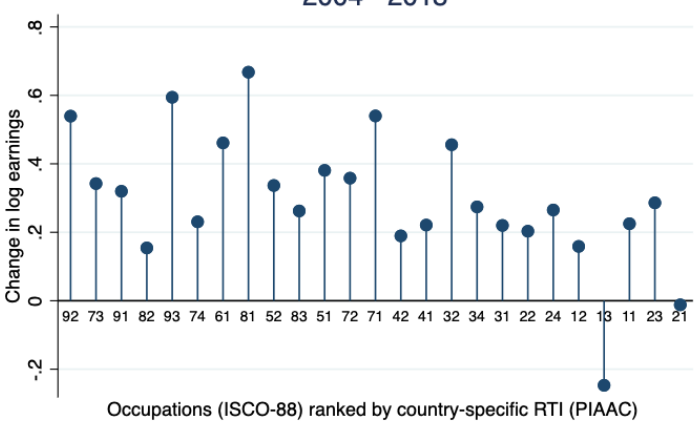


Figure 17: Changes in employment shares and earnings by occupation (ranked by their RTI)

Changes in employment

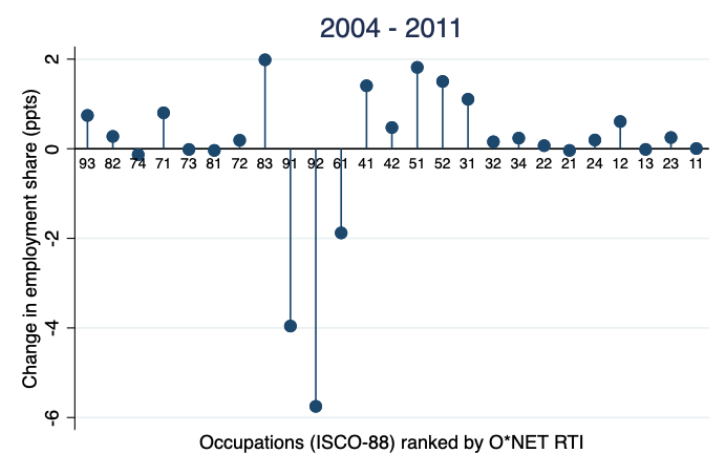

$2011-2018$

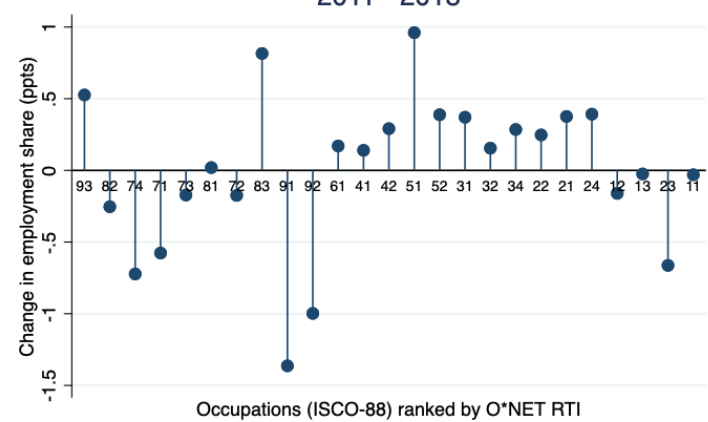

$2004-2018$

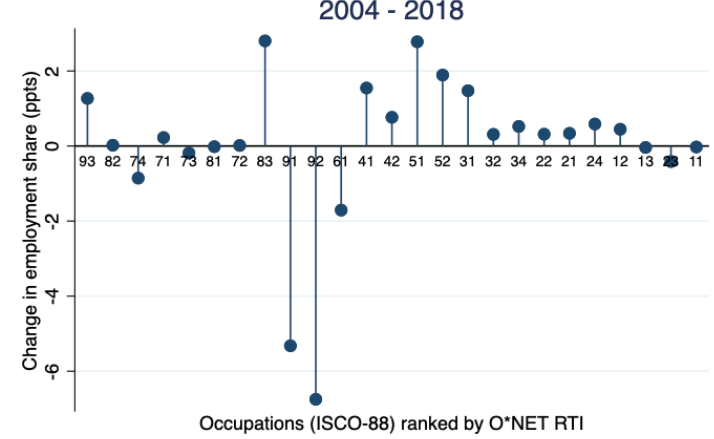

Source: authors' compilation based on data from ENAHO.
Changes in log earnings

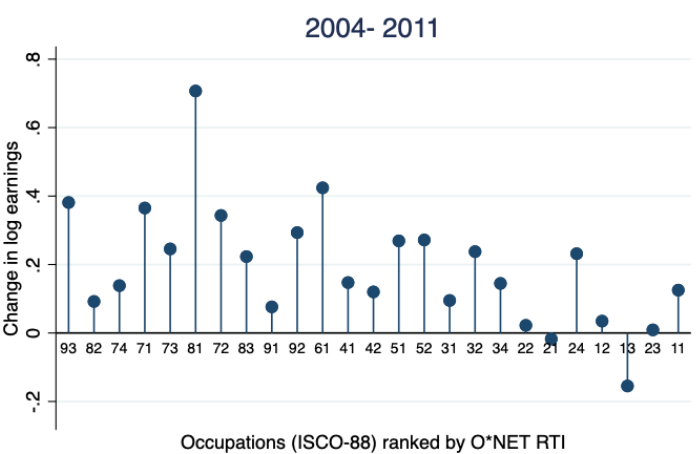

$2011-2018$

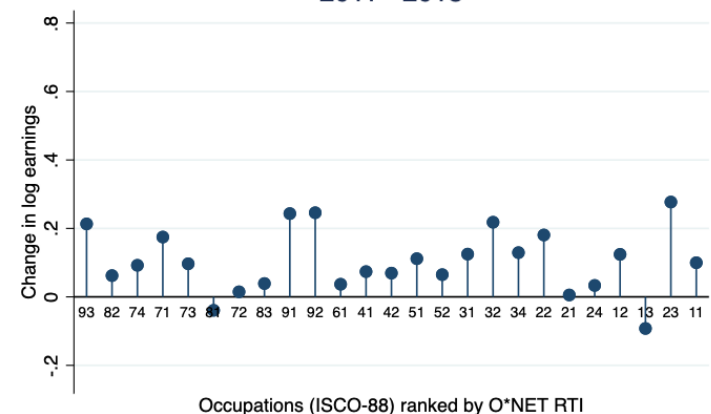

$2004-2018$

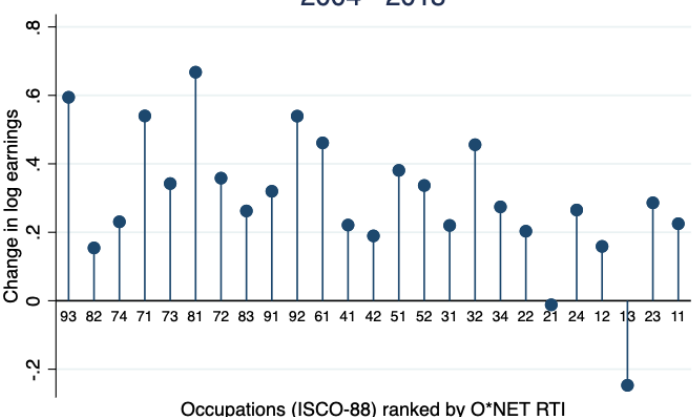

Occupations (ISCO-88) ranked by O*NET RTI 
The preceding analyses allowed us to look at factors that could explain the reduction in inequality between 2004 and 2018. Considering these factors as potential drivers of inequality, in this section we assess the specific weight that each of them may have in explaining the decrease in inequality for the period 2004-18. To do so we implement a Shapley decomposition of the Gini index and the RIF decomposition on quantiles and the Gini index (cf. Fortin et al. 2011). In addition, to appraise the effect of the mining commodities boom we specify a regression approach to measure the average effect of the shock on the Gini index using input-output technical coefficients.

The Shapley decomposition allows for an additive decomposition of a given inequality statistic. We implement it to identify the contribution of occupational (earnings and employment shares) heterogeneity to Peru's inequality trends. Table 3 presents this decomposition for the observed wage distribution (actual) and two alternative counterfactual distributions - shares constant and means constant - that assume constant occupational shares and constant occupational mean earnings, respectively. Although the inequality improvements between 2004-11 and 2011-18 are similar (around 0.03), the former period between-occupation improvement is the sharpest as it reduced from 0.199 in 2004 to 0.153 in 2011, staying constant until 2018. The within-occupation component played a minor role as it increased only slightly from 0.334 to 0.351 between 2004 and 2011, and then stayed constant until 2018 .

Whether the between-occupation improvement in inequality is explained by shifts in employment shares or mean earnings distributions across occupations (or both) is elucidated by the counterfactual decompositions. Keeping the employment shares constant at 2004 levels show that earnings inequality alone would have reduced the Gini index to levels that are almost identical to the current ones- that is, from 0.533 to 0.504 and 0.469 in 2011 and 2018, respectively. This suggests that shifts in occupational mean earnings were the key determinants of the inequality trends. Similarly, keeping occupational mean earnings constant at 2004 levels keeps inequality constant up to 2011 and reduces it only slightly up to 2018. This clearly points to shifts in occupational earnings distribution as the main driver of the inequality improvements during 2004-18.

The role of the RTI on the between-occupation Gini, proxied by the concentration indices ratio, stayed relatively constant up to 2018, although their magnitude suggests that the country-specific RTI (PIAAC) is more relevant than the $\mathrm{O}^{*}$ NET RTI to explain the between-occupation inequality trends.

Table 3: Gini decomposition: occupation and task content

\begin{tabular}{|c|c|c|c|c|c|c|c|c|c|}
\hline \multirow[b]{2}{*}{ Gini } & \multicolumn{3}{|c|}{ Actual } & \multicolumn{3}{|c|}{ Shares constant } & \multicolumn{3}{|c|}{ Means constant } \\
\hline & 2004 & 2011 & 2018 & 2004 & 2011 & 2018 & 2004 & 2011 & 2018 \\
\hline 1. Overall & 0.533 & 0.504 & 0.469 & 0.533 & 0.504 & 0.469 & 0.533 & 0.533 & 0.502 \\
\hline \multicolumn{10}{|l|}{ Shapley decomposition } \\
\hline 2. Between-occupation contribution & 0.199 & 0.153 & 0.152 & 0.199 & 0.149 & 0.148 & 0.199 & 0.201 & 0.202 \\
\hline Between-occ. relative contribution (2/1) & $37 \%$ & $30 \%$ & $32 \%$ & $37 \%$ & $30 \%$ & $32 \%$ & $37 \%$ & $38 \%$ & $40 \%$ \\
\hline 3. Within-occupation contribution & 0.334 & 0.351 & 0.351 & 0.334 & 0.355 & 0.321 & 0.334 & 0.333 & 0.300 \\
\hline Within-occ. relative contribution $(3 / 1)$ & $63 \%$ & $70 \%$ & $75 \%$ & $63 \%$ & $70 \%$ & $68 \%$ & $63 \%$ & $62 \%$ & $60 \%$ \\
\hline 4. Gini between occupations & 0.316 & 0.254 & 0.249 & 0.316 & 0.247 & 0.241 & 0.316 & 0.320 & 0.315 \\
\hline 5a. Concentration index (RTI O*NET) & 0.210 & 0.166 & 0.166 & 0.210 & 0.155 & 0.149 & 0.210 & 0.222 & 0.220 \\
\hline Relative concentration index $(5 \mathrm{a} / 4)$ & $67 \%$ & $65 \%$ & $67 \%$ & $67 \%$ & $63 \%$ & $62 \%$ & $67 \%$ & $69 \%$ & $70 \%$ \\
\hline 5b. Concentration index (RTI PIAAC) & 0.289 & 0.242 & 0.234 & 0.289 & 0.234 & 0.220 & 0.289 & 0.298 & 0.295 \\
\hline Relative concentration index $(5 \mathrm{~b} / 4)$ & $92 \%$ & $95 \%$ & $94 \%$ & $92 \%$ & $95 \%$ & $91 \%$ & $92 \%$ & $93 \%$ & $94 \%$ \\
\hline
\end{tabular}

Source: authors' compilation based on data from ENAHO. 
The RIF decomposition is a regression-based approach in which the dependent variable in this context is the quantile/Gini statistic obtained from workers' real earnings. The explanatory variables/drivers are workers' characteristics comprising education, age, gender, and the routine task content of occupations (RTI PIAAC). As such, the RIF decomposition shares the spirit of the Oaxaca-Blinder decomposition by allowing us to disentangle the 'explained' and 'unexplained' factors behind inequality. To perform the RIF decomposition on an aggregate measure such as a quantile or the Gini index, one needs to compute a counterfactual distribution. Following DiNardo et al. (1996; henceforth DFL), we estimate this counterfactual by reweighting the 2004 data to have the same distribution of covariates as in 2018 .

Appendix A7 presents the decomposition of earnings distribution deciles (10-90) and the Gini index between 2004-11, 2011-18, and 2004-18, which are summarized in Figures 18(a) and 18(b). From the reweighting decomposition (DFL) in Figure 18a, we identify that in both periods, 2004-11 and 2011-18, the earnings structure played a homogeneous role in the reduction of inequality, whereas the composition effect (workers' characteristics) contributed to a slight inequality rise during 2004-11. This is confirmed by the RIF aggregate decomposition (Figure 18b).

Breaking down the equality-enhancing earnings structure effects into specific determinants suggests that most of the drivers remain hidden (in the constant term). This may be interpreted as the aggregate effect of unobserved factors leading to a sustained equalizing effect in real earnings throughout the overall economy (Figure 18d). A second factor driving the equality-enhancing trend is gender, mostly during the 2004-11 period, which can be interpreted as the consequence of the narrowing of the real earnings gender gap. Similarly, we identify workers' returns on experience as a main inequality-increasing characteristic, mainly during the 2004-11 period.

The effects of shifts in workers' characteristics on the inequality rise mentioned above are attributed by the RIF composition effect (Figure18c). We find evidence that the main inequality-increasing factor was the occupational task content proxied by the RTI (PIAAC) during 2004-11 only. Similarly, workers' experience acted as an inequality-increasing characteristic during the whole 2004-18 period.

The DFL reweighting decomposition of the chosen quantiles provides a more insightful assessment than the Gini decomposition, as the former gives a profile characterization of the real earnings distribution. Our results show that workers' characteristics (composition effect) are less important than unexplained factors (earnings structure effect) at the lower tail of the earnings distribution, but, most importantly, that the relative importance of workers' characteristics tends to increase slightly as we move into the upper quantiles (Figure A4b). This is confirmed by the RIF aggregate decomposition (Figure A4a).

To zoom in on specific drivers explaining the inequality reduction, we report the RIF decomposition by characteristics (Figure A4c). We find that in upper quantiles improvements in the routine task content of occupations (RTI) were the drivers of real earnings growth (composition effect). Interestingly, 'poorer' workers exhibit a higher contribution of education into real earnings growth. Unexplained factors shaping the returns on workers' characteristics are identified by the RIF earnings structure decomposition (Figures A2d, A3d and A4d). This suggests that workers' returns on experience, gender, and other hidden factors (constant) were the main drivers of earnings growth across the whole distribution. Deciles around the median (40,50, and 60) exhibit a particular equality-enhancing behaviour as their earnings structure components tend to have a positive contribution to earnings growth (Figure A4d). This particular middle-class-enhancing behaviour was consistent across the 2004-18 period of analysis (Figures A2d and A3d). 
Figure 18: RIF: deciles and inequality decomposition (a) Reweighting decomposition
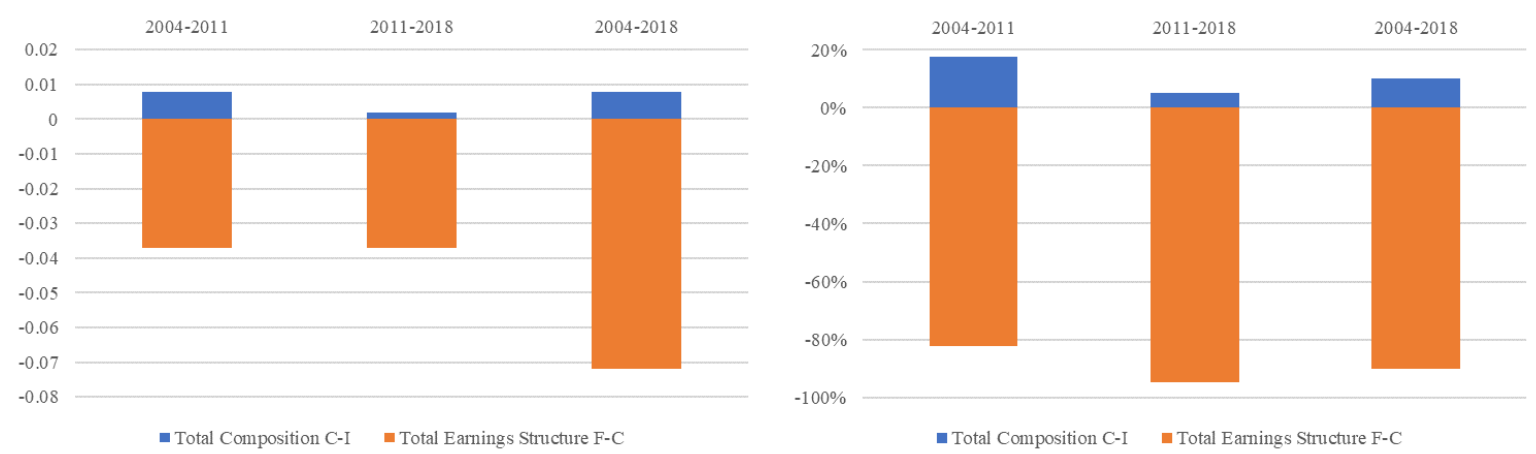

(b) RIF aggregate decomposition
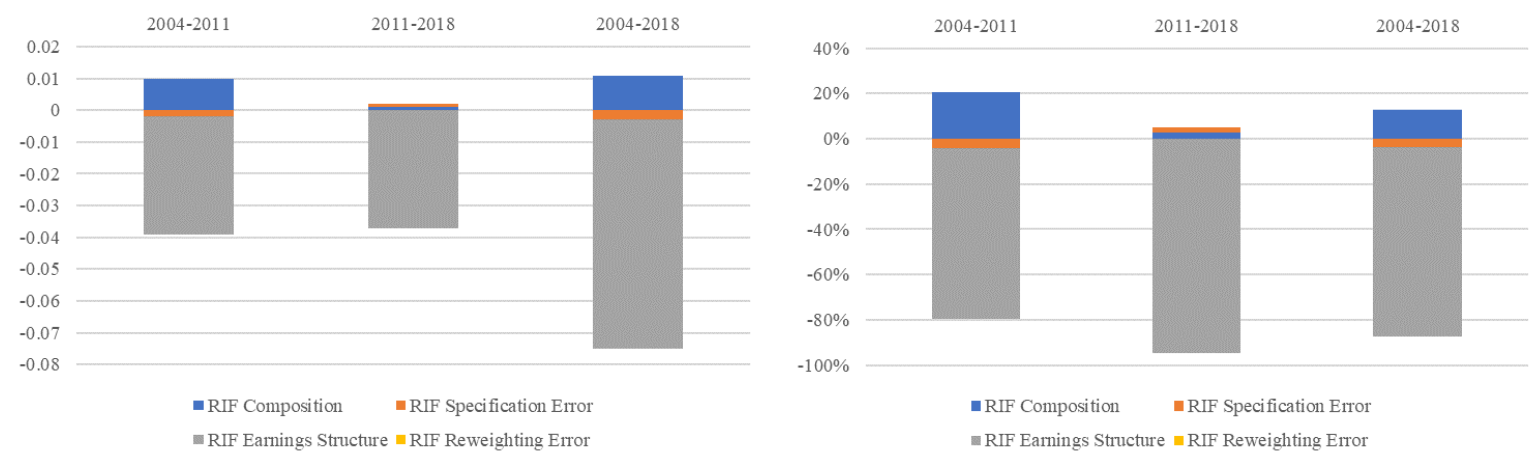

(c) RIF composition
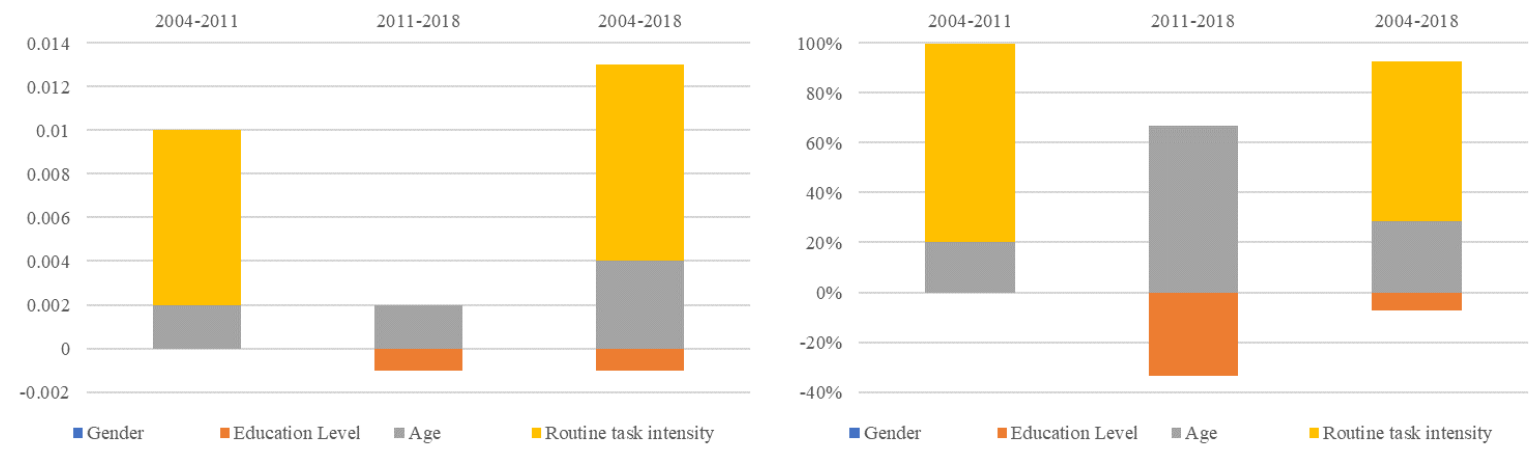

(d) RIF earnings structure
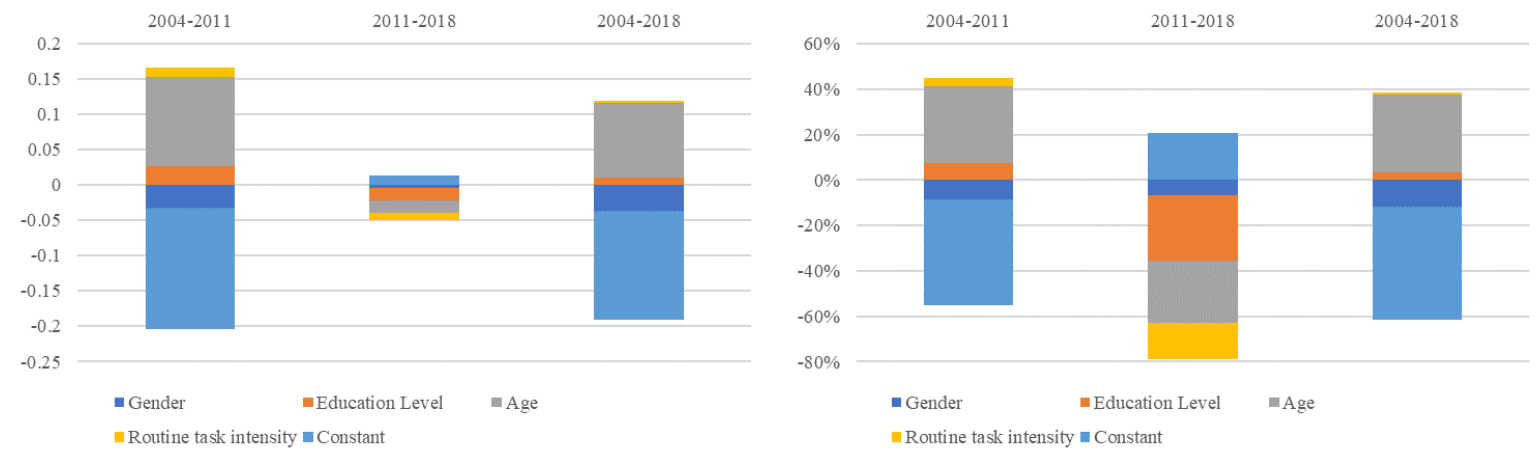

Source: authors' compilation based on data from ENAHO.

\subsection{Mining commodities boom}

In the latest decades around 60 per cent of exports from Peru were mining commodities. In 2017, copper, gold, and zinc alone accounted for 89 per cent of total mining exports (Belapatiño et al. 2019). Although 
mining activities are known to be capital intensive, they may induce indirect effects on the rest of the economy through the demand for intermediate goods and services, and also through the demand for final goods in the form of infrastructure.

Thus, a key potential determinant of inequality reduction in Peru is the mining commodities boom, ${ }^{3}$ a factor we did not include in the RIF decomposition as the variation in commodity prices between 2004 and 2018 was significant. As such, it was not possible to reweight the 2004 data to obtain a counterfactual distribution that exhibits similar average values as the original one.

To account for this driver, we rely on the exogenous variation of international commodities prices that impacted the economy through spillover effects proxied by an input-output analysis and estimate the effect of the commodities prices shocks on real labour earnings (Gini index) for 2004-18. To do so we make use of the Leontief technical relationship and construct two sectoral-level indices that reflect the commodity price effects through mining (intermediate demand) and construction (final demand) on all economic activities. Then, both indices are used as explanatory variables in a real earnings regressionbased analysis allowing the estimation of the average effect of the commodity price shocks on the Gini index.

We now describe the Leontief relationship for Peru using the 2007 input-output matrix (I-O). This matrix relates the value of sectoral production to the value of sectoral intermediate and final demand for goods and services as follows:

$$
q=A q+f
$$

where $q$ is the total production (value) vector across economic sectors (one-digit level, CIIU rev. 4), $A q$ is the intermediate demand (value) vector, and $f$ is the final goods demand vector. The technical coefficients $\left(A_{i j}\right)$ represent the $j$ th sector intermediate goods demand from the $i$ th sector with respect to the $j$ th sector total production.

To approximate the effect of international commodity prices on the production value of sectors, we assume that a 1 per cent increase in international commodity prices for the mining sector leads to a 1 per cent increase on its final demand value. Formally,

$$
d q=M d f
$$

where $M=(I-A)^{-1}$ is a matrix of multipliers that allows us to map the effects of final demand shocks such as the commodity prices on the production value of sectors. Tables A16 and A17 report the technical coefficients and multipliers, respectively. From these we see that the manufacturing and services sectors exhibit the highest linkages with the mining industry. Assuming the technical coefficients to be stable (constant) during our period of analysis, the change in the sectoral production value $d q_{t}$ is given by the product of the change in commodity prices at time $t\left(d f m_{t}\right)$ and the multiplier effect on other sectors of the economy $\left(M_{. m}\right)$ :

$$
d q_{t}=M_{. m} d f_{m t}
$$

The column vector $M_{. m}$. is the mining sector multiplier reported in the third column of the $M$ matrix (Table A17). Note that the third row has a value closer to unity (1.07), which corresponds to the multiplier effect of the mining sector itself. Since we are interested in the definition of an index that proxies the effects of the commodities shock through mining, we normalize the first period of $q_{t}$ to 1 for every sector in 2004 and then extrapolate this normalized production value $\tilde{q}_{t}$ up to $2018 .{ }^{4}$ The extrapolation

\footnotetext{
${ }^{3}$ See, for instance, Loayza and Rigolini (2016) and Ticci and Escobal (2015)

${ }^{4}$ Formally the baseline index values are defined as $q_{2004}=\tilde{q}_{2004}=\mathbf{1}$.
} 
is carried out by inputting $f_{m t}$ from a mining commodity price index growth rate. ${ }^{5}$ This yields a longitudinal series of the commodity shock index through mining $\tilde{q}_{j t}$ for nine economic sectors from 2004 to 2018.

To proxy the effects of the commodities shock through construction - the demand for infrastructure from mining activities - we compute the change in the sectoral production value resulting from a change in the final demand of the construction sector (Equation 1). We normalize it $\left(q_{2004}=\bar{q}_{2004}=\mathbf{1}\right)$ and obtain a longitudinal series for the commodity shock index through construction $\bar{q}_{j t}$ for the nine economic sectors from 2004 to 2018. Column 6 in Table A17 shows that the main indirect effects are channelled through manufacturing $(0.56)$ followed by the services sector $(0.11)$.

\section{The regression-based approach}

We now assess the effects of the mining commodities boom on inequality at the individual level $(i)$. To do so we use the pooled household cross-sections of 2004-18 and merge them with the longitudinal series of indices of commodity shocks by sector $(j)$ computed previously. To account for the observed heterogeneity across education levels and gender, we specify a regression model of real earnings for every combination of gender and education level. ${ }^{6}$ The covariates included in the $x_{i t}$ vector comprise the individual's age, age squared, and routine task content:

$$
y_{i j t}=x_{i t}^{\prime} \beta+\gamma_{1} \tilde{q}_{j t}+\gamma_{2} q_{j t}+u_{j}+u_{c}+u_{r}+u_{t}+\varepsilon_{i j t}
$$

To account for unobserved characteristics that remain invariant across individuals in a given sector, we include fixed effects of economic sector $\left(u_{j}\right)$, occupation $\left(u_{c}\right)$, geographic location $\left(u_{r}\right)$, and time $\left(u_{t}\right)$. Our terms of interest are $\gamma_{1} \tilde{q}_{j t}$ and $\gamma_{2} q_{j t}$, and measure the (log) real earnings effects of the mining commodities shock channelled throughout the sectors by gender and education. From this specification we obtain a counterfactual outcome $\mathbf{y}_{\mathbf{i j}}$, defined as the $(\log )$ real earnings given the commodity prices of $2004 .^{7}$

Table 4 presents the Gini index under the observed and counterfactual distributions. The latter represents a situation without an increase in commodity prices and points to a statistically significant difference across our period of analysis. ${ }^{8}$ The results are in line with those of Loayza and Rigolini (2016) on consumption expenditure. Labour income inequality was expected to rise up to 0.52 compared to the current 0.47 in 2018 . Alternative redistributive mechanisms have been triggered by the mining canon, a mining tax that is redistributed across the mining regions in the form of public expenditures and subsidies to households. The slight effect on the Gini coefficient suggests that our RIF regression decomposition may still be informative, but not conclusive enough.

\footnotetext{
${ }^{5}$ Since most of Peru's mining production relies on copper, gold, and zinc, we build a composite price index from the weighted average yearly growth rate where the weights are calculated according to the historical specific weight of these three minerals in Peru's exports.

${ }^{6}$ No schooling, primary, secondary, and tertiary education.

${ }^{7}$ In practice we calculate the counterfactual by partialling out the effect of international commodity prices after 2004: $\mathbf{y}_{\mathbf{i j t}}=$ $y_{i j t}-\left(\gamma_{1}\left(\tilde{q}_{j t}-\tilde{q}_{j 0}\right)+\gamma_{2}\left(q_{j t}-q_{j 0}\right)\right)$. Since both indices are normalized to 1 in $2004, \tilde{q}_{j 0}=q_{j 0}=1$.

${ }^{8}$ Statistical inference is performed using the delta method and the survey sampling weights using DASP (Araar and Duclos 2007).
} 
Table 4: Mineral prices effects (average treatment effect) on inequality (Gini)

\begin{tabular}{ccccc}
\hline & Observed & Counterfactual & Diff. & $P$ value \\
\hline 2011 & 0.502 & 0.576 & 0.074 & 0.000 \\
2018 & 0.469 & 0.524 & 0.054 & 0.000 \\
\hline
\end{tabular}

Note: counterfactual distribution assumes mineral prices of 2004.

Source: authors' compilation based on data from ENAHO.

\section{$4 \quad$ Concluding remarks}

In this paper we looked for SBTC patterns that may have driven Peru's inequality dynamics during its latest trade liberalization episode, from the mid-2000s to 2018, with a particular focus on labour market earnings. Our results using labour income are in line with other studies' findings performed over alternative welfare indicators (household expenditure and total income), which show that inequality has improved slightly during the period of analysis (Herrera 2017). By exploring the structural changes in labour market characteristics, we identify concurrent shifts that explain the inequality dynamics. Specifically, the labour force skill level distribution exhibits a clear trend towards shifting from low to medium skill levels. Furthermore, this 'transition' correlates with labour earnings increasing the most for the lowest-paid occupations, thus supporting the equalizing dynamics in labour earnings distribution, in particular during the 2004-11 period. Considering a more nuanced approach to the potential SBTC effects by focusing on the routine task content of occupations (RTI PIAAC) leads to similar conclusions; this labour structural change is characterized by a clear transition from routine to less routine (and better paid) occupations. ${ }^{9}$

The shift from low- to medium-skilled occupations comes with an improvement in workers' levels of education. Tertiary-educated workers shifted from 24 per cent in 2004 to 34 per cent in 2018, while primary-educated workers fell from 27 per cent to 20 per cent in the same period. Our DFL (reweighting) and RIF decomposition analyses shed light on the specific contribution of such structural changes (skills and education) on inequality. We find that workers' characteristics are less important than unexplained factors (earnings structure) and that the relative importance of workers' characteristics tends to increase only slightly as we move into higher quantiles. Despite the minor role of observed characteristics in earnings growth, we find that the task content of occupations is a main component of the latter. Specifically, its importance increases as we move from 'poorer' to 'richer' workers. At the contrary, education shows larger specific weights in the 'poorer' deciles, suggesting it could be an equality-enhancing factor.

Our findings are in line with other studies seeking to identify SBTC links in Latin American countries' inequality trends, Peru among them (Maloney and Molina 2016; Messina and Silva 2017). We argue that technological change complementarities (with high-skilled, non-routine occupations) and substitution patterns (with low-skilled, routine occupations) might not be the main drivers of the inequality dynamics in these developing economies. These countries were mainly affected by a commodities boom in specific economic sectors (agriculture and mining) that are rather intensive in medium- or low-skilled workers rather than high-skilled, and for whom technological change might not play a main role. From an additional investigation whose purpose was to identify the potential effect of the mining commodities boom on inequality, we confirm that mineral prices effects on income inequality were inequalityincreasing, thus supporting the view of extractivism as a pervasive driver of inequality. In this context, a perspective that considers labour mobility costs as a key moderator of trade effects may be better suited to explain Peru's modest but still improving equality trends (Baldárrago and Salinas 2017).

\footnotetext{
${ }^{9}$ From elementary occupations and 'skilled' agriculture and fishery workers to less routine occupations such as service, shop, and market workers, and plant and machine operators and assemblers, among others.
} 


\section{References}

Acemoglu, D., and P. Restrepo (2020). 'Robots and Jobs: Evidence from US Labor Markets'. Journal of Political Economy, 128(6): 2188-244. https://doi.org/10.1086/705716

Araar, A., and J.-Y. Duclos (2007). 'DASP: Distributive Analysis Stata Package'. Quebec City: PEP, World Bank, UNDP, and Université Laval.

Artuc, E., D. Lederman, and G. Porto (2015). 'A Mapping of Labor Mobility Costs in the Developing World'. Journal of International Economics, 95(1): 28-41.

Autor, D.H. and D. Dorn (2013). 'The Growth of Low-Skill Service Jobs and the Polarization of the US Labor Market'. American Economic Review, 103(5): 1553-97. https://doi.org/10.1257/aer.103.5.1553

Baldárrago, E., and G. Salinas (2017). 'Trade Liberalization in Peru: Adjustment Costs Amidst High Labor Mobility’. Technical Report. Washington, DC: International Monetary Fund.

Belapatiño, V., Y. Crispin, and F. Grippa (2019). 'Perú: situación del sector minero'. Report. Available at: www. bbvaresearch.com/publicaciones/peru-situacion-del-sector-minero-febrero-2019.

Besley, T., and R. Burgess (2004). 'Can Labor Regulation Hinder Economic Performance? Evidence from India'. Quarterly Journal of Economics, 119(1): 91-134. https://doi.org/10.1162/003355304772839533

Botero, J.C., S. Djankov, R.L. Porta, F. Lopez-de-Silanes, and A. Shleifer (2004). 'The Regulation of Labor'. Quarterly Journal of Economics, 119(4): 1339-82. https://doi.org/10.1162/0033553042476215

Caselli, F., and G. Michaels (2013). 'Do Oil Windfalls Improve Living Standards? Evidence from Brazil'. American Economic Journal: Applied Economics, 5(1): 208-38. https://doi.org/10.1257/app.5.1.208

DiNardo, J., N.M. Fortin, and T. Lemieux (1996). 'Labor Market Institutions and the Distribution of Wages, 1973-1992: A Semiparametric Approach'. Econometrica, 64(5): 1001-44. https://doi.org/10.2307/2171954

Fortin, N., T. Lemieux, and S. Firpo (2011). 'Decomposition Methods in Economics'. In O. Ashenfelter and D. Card (eds) Handbook of Labor Economics, vol. 4, pp. 1-102. Amsterdam: Elsevier.

Foster, J.E., and M.C. Wolfson (2010). 'Polarization and the Decline of the Middle Class: Canada and the US'. Journal of Economic Inequality, 8(2): 247-73. https://doi.org/10.1007/s10888-009-9122-7

Goos, M., and A. Manning (2007). 'Lousy and Lovely Jobs: The Rising Polarization of Work in Britain'. Review of Economics and Statistics, 89(1): 118-33. https://doi.org/10.1162/rest.89.1.118

Herrera, J. (2017). 'Poverty and Economic Inequalities in Peru during the Boom in Growth: 2004-14'. International Development Policyl Revue internationale de politique de développement, 9(9): 138-73. https: //doi.org/10.4000/poldev.2363

ILO (2017). 'Panorama Laboral 2017'. Technical Report. Geneva: International Labour Organization.

INEI (2015). 'Clasificador Nacional De Ocupaciones'. Technical Report. Lima: Instituto Nacional de Estadística e Informática.

INEI (2018). 'Producción y empleo informal en el Perú'. Technical Report. Lima: Instituto Nacional de Estadística e Informática.

Lewandowski, P., A. Park, and S. Schotte (2020). 'The Global Distribution of Routine and Non-Routine Work'. UNU-WIDER Working Paper 75/2020. Helsinki: UNU-WIDER. https://doi.org/10.35188/UNU-WIDER/ 2020/832-0

Loayza, N., and J. Rigolini (2016). 'The Local Impact of Mining on Poverty and Inequality: Evidence from the Commodity Boom in Peru'. World Development 84: 219-34. https://doi.org/10.1016/j.worlddev.2016.03.005

Maloney, W.F., and C. Molina (2016). 'Are Automation and Trade Polarizing Developing Country Labor Markets, Too?' Policy Research Working Paper 7922. Washington, DC: World Bank. https://oi.org/10.1596/ 1813-9450-7922 
Messina, J., and J. Silva (2017). Wage Inequality in Latin America: Understanding the Past to Prepare for the Future. Washington, DC: World Bank.

Pavcnik, N. (2003). 'What Explains Skill Upgrading in Less Developed Countries?' Journal of Development Economics, 71(2): 311-28. https://doi.org/10.1016/S0304-3878(03)00031-2

Pavcnik, N. (2017). 'The Impact of Trade on Inequality in Developing Countries'. Working Paper 23878. Cambridge, MA: National Bureau of Economic Research. https://doi.org/10.3386/w23878

Sebastian, R. (2018). 'Explaining Job Polarisation in Spain from a Task Perspective'. SERIEs, 9(2): 215-48. https://doi.org/10.1007/s13209-018-0177-1

Ticci, E., and J. Escobal (2015). 'Extractive Industries and Local Development in the Peruvian Highlands'. Environment and Development Economics, 20(1): 101-26. https://doi.org/10.1017/S1355770X13000685 


\section{Appendix}

\section{A1 Real earnings inequality statistics}

Table A1: Real earnings decile shares, 2004-18

\begin{tabular}{ccccccccccc}
\hline & $0-10$ & $10-20$ & $20-30$ & $30-40$ & $40-50$ & $50-60$ & $60-70$ & $70-80$ & $80-90$ & $90-100$ \\
\hline 2004 & 0.007 & 0.019 & 0.031 & 0.043 & 0.057 & 0.073 & 0.091 & 0.117 & 0.156 & 0.405 \\
2005 & 0.008 & 0.019 & 0.030 & 0.042 & 0.057 & 0.073 & 0.092 & 0.116 & 0.158 & 0.406 \\
2006 & 0.008 & 0.019 & 0.030 & 0.043 & 0.058 & 0.073 & 0.092 & 0.118 & 0.160 & 0.399 \\
2007 & 0.006 & 0.017 & 0.029 & 0.042 & 0.056 & 0.070 & 0.089 & 0.117 & 0.162 & 0.411 \\
2008 & 0.006 & 0.018 & 0.031 & 0.044 & 0.058 & 0.073 & 0.091 & 0.119 & 0.161 & 0.398 \\
2009 & 0.006 & 0.018 & 0.031 & 0.045 & 0.058 & 0.073 & 0.091 & 0.118 & 0.161 & 0.398 \\
2010 & 0.007 & 0.019 & 0.033 & 0.047 & 0.060 & 0.075 & 0.093 & 0.119 & 0.160 & 0.388 \\
2011 & 0.007 & 0.020 & 0.035 & 0.049 & 0.062 & 0.076 & 0.094 & 0.119 & 0.160 & 0.377 \\
2012 & 0.007 & 0.021 & 0.035 & 0.049 & 0.063 & 0.077 & 0.096 & 0.119 & 0.159 & 0.375 \\
2013 & 0.007 & 0.021 & 0.035 & 0.051 & 0.066 & 0.080 & 0.098 & 0.121 & 0.161 & 0.360 \\
2014 & 0.008 & 0.022 & 0.036 & 0.052 & 0.065 & 0.080 & 0.098 & 0.122 & 0.162 & 0.355 \\
2015 & 0.008 & 0.023 & 0.038 & 0.053 & 0.066 & 0.080 & 0.097 & 0.120 & 0.160 & 0.355 \\
2016 & 0.008 & 0.022 & 0.036 & 0.052 & 0.065 & 0.079 & 0.097 & 0.121 & 0.161 & 0.359 \\
2017 & 0.008 & 0.022 & 0.037 & 0.053 & 0.066 & 0.081 & 0.098 & 0.121 & 0.164 & 0.350 \\
2018 & 0.008 & 0.023 & 0.038 & 0.054 & 0.067 & 0.081 & 0.099 & 0.124 & 0.165 & 0.342 \\
\hline
\end{tabular}

Source: authors' compilation based on data from ENAHO.

Table A2: Real earnings interquantile ratios, 2004-18

\begin{tabular}{cccc}
\hline & $\ln (q 90)-\ln (q 10)$ & $\ln (q 90)-\ln (q 50)$ & $\ln (q 50)-\ln (q 10)$ \\
\hline 2004 & 2.68 & 1.06 & 1.62 \\
2005 & 2.67 & 1.07 & 1.60 \\
2006 & 2.66 & 1.06 & 1.60 \\
2007 & 2.81 & 1.15 & 1.66 \\
2008 & 2.83 & 1.11 & 1.72 \\
2009 & 2.80 & 1.12 & 1.69 \\
2010 & 2.77 & 1.07 & 1.70 \\
2011 & 2.67 & 1.03 & 1.64 \\
2012 & 2.63 & 1.02 & 1.61 \\
2013 & 2.64 & 1.00 & 1.65 \\
2014 & 2.58 & 1.00 & 1.58 \\
2016 & 2.55 & 0.98 & 1.57 \\
2017 & 2.61 & 1.01 & 1.59 \\
2018 & 2.59 & 1.01 & 1.58 \\
2018 & 2.58 & 1.01 & 1.57 \\
\hline
\end{tabular}

Source: authors' compilation based on data from ENAHO. 
Table A3: Summary indices for real earnings, 2004-18

\begin{tabular}{ccccc}
\hline & $\operatorname{Var} \operatorname{In}(y)$ & Gini In $(y)$ & Std $y$ & Gini $y$ \\
\hline 2004 & 1.22 & 0.13 & 342.12 & 0.53 \\
2005 & 1.22 & 0.13 & 313.57 & 0.53 \\
2006 & 1.22 & 0.13 & 304.79 & 0.53 \\
2007 & 1.35 & 0.13 & 388.44 & 0.54 \\
2008 & 1.37 & 0.13 & 360.21 & 0.53 \\
2009 & 1.36 & 0.13 & 366.66 & 0.53 \\
2010 & 1.31 & 0.12 & 377.07 & 0.52 \\
2011 & 1.24 & 0.12 & 365.50 & 0.50 \\
2012 & 1.21 & 0.12 & 376.99 & 0.50 \\
2013 & 1.21 & 0.12 & 343.06 & 0.49 \\
2014 & 1.16 & 0.11 & 340.52 & 0.48 \\
2016 & 1.12 & 0.11 & 352.80 & 0.48 \\
2017 & 1.15 & 0.11 & 345.55 & 0.48 \\
2018 & 1.13 & 0.11 & 335.22 & 0.48 \\
2018 & 1.11 & 0.11 & 306.68 & 0.47 \\
\hline
\end{tabular}

Source: authors' compilation based on data from ENAHO. 
Table A4: Log earnings OLS: male population

\begin{tabular}{|c|c|c|c|c|c|c|c|c|c|c|c|c|c|c|c|}
\hline & 2004 & 2005 & 2006 & 2007 & 2008 & 2009 & 2010 & 2011 & 2012 & 2013 & 2014 & 2015 & 2016 & 2017 & 2018 \\
\hline \multicolumn{16}{|c|}{ Education level (base: no schooling) } \\
\hline Primary & $\begin{array}{c}0.50^{* * *} \\
(0.06)\end{array}$ & $\begin{array}{c}0.36^{* * *} \\
(0.05)\end{array}$ & $\begin{array}{c}0.49^{* * *} \\
(0.05)\end{array}$ & $\begin{array}{c}0.36^{* * *} \\
(0.06)\end{array}$ & $\begin{array}{c}0.39^{* * *} \\
(0.06)\end{array}$ & $\begin{array}{c}0.23^{* * *} \\
(0.07)\end{array}$ & $\begin{array}{c}0.27^{* * *} \\
(0.07)\end{array}$ & $\begin{array}{c}0.32^{* * *} \\
(0.06)\end{array}$ & $\begin{array}{c}0.35^{* * *} \\
(0.07)\end{array}$ & $\begin{array}{c}0.30^{* * *} \\
(0.06)\end{array}$ & $\begin{array}{c}0.35^{* * *} \\
(0.06)\end{array}$ & $\begin{array}{c}0.51^{* * *} \\
(0.07)\end{array}$ & $\begin{array}{c}0.30^{* * *} \\
(0.07)\end{array}$ & $\begin{array}{c}0.22 * * * \\
(0.06)\end{array}$ & $\begin{array}{c}0.40^{* * *} \\
(0.07)\end{array}$ \\
\hline Secondary & $\begin{array}{c}0.96^{* * *} \\
(0.05)\end{array}$ & $\begin{array}{c}0.89^{* * *} \\
(0.05)\end{array}$ & $\begin{array}{c}0.99^{* * *} \\
(0.05)\end{array}$ & $\begin{array}{c}0.81^{* * *} \\
(0.06)\end{array}$ & $\begin{array}{c}0.85^{* * *} \\
(0.06)\end{array}$ & $\begin{array}{c}0.61^{* * *} \\
(0.07)\end{array}$ & $\begin{array}{c}0.66^{* * *} \\
(0.06)\end{array}$ & $\begin{array}{c}0.72^{* * *} \\
(0.06)\end{array}$ & $\begin{array}{c}0.77^{* * *} \\
(0.07)\end{array}$ & $\begin{array}{c}0.72^{* * *} \\
(0.06)\end{array}$ & $\begin{array}{c}0.82^{* * *} \\
(0.06)\end{array}$ & $\begin{array}{c}0.97^{* * *} \\
(0.07)\end{array}$ & $\begin{array}{c}0.78^{* * *} \\
(0.07)\end{array}$ & $\begin{array}{c}0.73^{* * *} \\
(0.06)\end{array}$ & $\begin{array}{c}0.83^{* * *} \\
(0.07)\end{array}$ \\
\hline Tertiary & $\begin{array}{c}1.63^{* * *} \\
(0.06)\end{array}$ & $\begin{array}{c}1.49^{* * *} \\
(0.06)\end{array}$ & $\begin{array}{c}1.65^{* * *} \\
(0.05)\end{array}$ & $\begin{array}{c}1.50^{* * *} \\
(0.06)\end{array}$ & $\begin{array}{c}1.45^{* * *} \\
(0.06)\end{array}$ & $\begin{array}{c}1.21^{* * *} \\
(0.07)\end{array}$ & $\begin{array}{c}1.18^{* * *} \\
(0.07)\end{array}$ & $\begin{array}{c}1.22^{* * *} \\
(0.07)\end{array}$ & $\begin{array}{c}1.27^{* * *} \\
(0.07)\end{array}$ & $\begin{array}{c}1.24^{* * *} \\
(0.06)\end{array}$ & $\begin{array}{c}1.33^{* * *} \\
(0.06)\end{array}$ & $\begin{array}{c}1.45^{* * *} \\
(0.07)\end{array}$ & $\begin{array}{c}1.28^{* * *} \\
(0.07)\end{array}$ & $\begin{array}{c}1.22^{* * *} \\
(0.06)\end{array}$ & $\begin{array}{c}1.33^{* * *} \\
(0.07)\end{array}$ \\
\hline Constant & $\begin{array}{c}3.88^{* * *} \\
(0.05)\end{array}$ & $\begin{array}{c}3.97^{* * *} \\
(0.05)\end{array}$ & $\begin{array}{c}3.90^{* * *} \\
(0.05)\end{array}$ & $\begin{array}{c}4.10^{* * *} \\
(0.06)\end{array}$ & $\begin{array}{c}4.17^{* * *} \\
(0.06)\end{array}$ & $\begin{array}{c}4.46^{* * *} \\
(0.06)\end{array}$ & $\begin{array}{c}4.47^{* * *} \\
(0.06)\end{array}$ & $\begin{array}{c}4.46^{* * *} \\
(0.06)\end{array}$ & $\begin{array}{c}4.45^{* * *} \\
(0.07)\end{array}$ & $\begin{array}{c}4.51^{* * *} \\
(0.06)\end{array}$ & $\begin{array}{c}4.45^{* * *} \\
(0.06)\end{array}$ & $\begin{array}{c}4.32^{* * *} \\
(0.07)\end{array}$ & $\begin{array}{c}4.51^{* * *} \\
(0.07)\end{array}$ & $\begin{array}{c}4.56^{* * *} \\
(0.06)\end{array}$ & $\begin{array}{c}4.44^{* * *} \\
(0.07)\end{array}$ \\
\hline Observations & 19,370 & 19,074 & 20,351 & 21,912 & 21,219 & 21,557 & 21,193 & 24,146 & 24,009 & 28,377 & 28,101 & 28,376 & 31,183 & 29,699 & 31,479 \\
\hline R-squared & 0.18 & 0.17 & 0.18 & 0.17 & 0.15 & 0.13 & 0.11 & 0.12 & 0.12 & 0.12 & 0.14 & 0.13 & 0.14 & 0.14 & 0.13 \\
\hline
\end{tabular}

Note: standard errors in parentheses. ${ }^{*} p<0.1,{ }^{* *} p<0.05,{ }^{* * *} p<0.01$.

Source: authors' compilation based on data from ENAHO. 
Table A5: Log earnings OLS: female population

\begin{tabular}{|c|c|c|c|c|c|c|c|c|c|c|c|c|c|c|c|}
\hline & 2004 & 2005 & 2006 & 2007 & 2008 & 2009 & 2010 & 2011 & 2012 & 2013 & 2014 & 2015 & 2016 & 2017 & 2018 \\
\hline \multicolumn{16}{|c|}{ Education level (base: no schooling) } \\
\hline Primary & $\begin{array}{c}0.42^{* * *} \\
(0.05)\end{array}$ & $\begin{array}{c}0.54^{* * *} \\
(0.06)\end{array}$ & $\begin{array}{c}0.50^{* * *} \\
(0.05)\end{array}$ & $\begin{array}{c}0.41^{* * *} \\
(0.06)\end{array}$ & $\begin{array}{c}0.47^{* * *} \\
(0.06)\end{array}$ & $\begin{array}{c}0.48^{* * *} \\
(0.05)\end{array}$ & $\begin{array}{c}0.34^{* * *} \\
(0.06)\end{array}$ & $\begin{array}{c}0.40^{* * * *} \\
(0.05)\end{array}$ & $\begin{array}{c}0.54^{* * *} \\
(0.06)\end{array}$ & $\begin{array}{c}0.42^{* * *} \\
(0.06)\end{array}$ & $\begin{array}{c}0.46^{* * *} \\
(0.05)\end{array}$ & $\begin{array}{c}0.34^{* * *} \\
(0.05)\end{array}$ & $\begin{array}{c}0.33^{* * *} \\
(0.05)\end{array}$ & $\begin{array}{c}0.43^{* * *} \\
(0.05)\end{array}$ & $\begin{array}{c}0.25^{* * *} \\
(0.05)\end{array}$ \\
\hline Secondary & $\begin{array}{c}0.87^{* * *} \\
(0.05)\end{array}$ & $\begin{array}{c}1.02^{* * *} \\
(0.05)\end{array}$ & $\begin{array}{c}0.91^{* * *} \\
(0.05)\end{array}$ & $\begin{array}{c}0.92^{* * *} \\
(0.05)\end{array}$ & $\begin{array}{c}0.92^{* * *} \\
(0.05)\end{array}$ & $\begin{array}{c}0.88^{* * *} \\
(0.05)\end{array}$ & $\begin{array}{c}0.72^{* * *} \\
(0.06)\end{array}$ & $\begin{array}{c}0.75^{* * *} \\
(0.05)\end{array}$ & $\begin{array}{c}0.91^{* * *} \\
(0.06)\end{array}$ & $\begin{array}{c}0.84^{* * *} \\
(0.06)\end{array}$ & $\begin{array}{c}0.88^{* * * *} \\
(0.05)\end{array}$ & $\begin{array}{c}0.79^{* * *} \\
(0.05)\end{array}$ & $\begin{array}{c}0.76^{* * *} \\
(0.05)\end{array}$ & $\begin{array}{c}0.87^{* * *} \\
(0.05)\end{array}$ & $\begin{array}{c}0.72^{* * *} \\
(0.05)\end{array}$ \\
\hline Tertiary & $\begin{array}{c}1.53^{* * *} \\
(0.05)\end{array}$ & $\begin{array}{c}1.62^{* * *} \\
(0.06)\end{array}$ & $\begin{array}{c}1.65^{* * *} \\
(0.06)\end{array}$ & $\begin{array}{c}1.68^{* * *} \\
(0.06)\end{array}$ & $\begin{array}{c}1.64^{* * *} \\
(0.06)\end{array}$ & $\begin{array}{c}1.61^{* * *} \\
(0.05)\end{array}$ & $\begin{array}{c}1.40^{* * *} \\
(0.06)\end{array}$ & $\begin{array}{c}1.40^{* * *} \\
(0.05)\end{array}$ & $\begin{array}{c}1.58^{* * *} \\
(0.06)\end{array}$ & $\begin{array}{c}1.53^{* * *} \\
(0.06)\end{array}$ & $\begin{array}{c}1.56^{* * *} \\
(0.05)\end{array}$ & $\begin{array}{c}1.47^{* * *} \\
(0.05)\end{array}$ & $\begin{array}{c}1.49^{* * *} \\
(0.05)\end{array}$ & $\begin{array}{c}1.51^{* * *} \\
(0.05)\end{array}$ & $\begin{array}{c}1.39^{* * * *} \\
(0.05)\end{array}$ \\
\hline Constant & $\begin{array}{c}3.57^{* * *} \\
(0.05)\end{array}$ & $\begin{array}{c}3.43^{* * *} \\
(0.05)\end{array}$ & $\begin{array}{c}3.54^{* * *} \\
(0.05)\end{array}$ & $\begin{array}{c}3.50^{* * *} \\
(0.05)\end{array}$ & $\begin{array}{c}3.50^{* * *} \\
(0.05)\end{array}$ & $\begin{array}{c}3.58^{* * *} \\
(0.05)\end{array}$ & $\begin{array}{c}3.77^{* * *} \\
(0.05)\end{array}$ & $\begin{array}{c}3.82^{* * *} \\
(0.05)\end{array}$ & $\begin{array}{c}3.72^{* * *} \\
(0.05)\end{array}$ & $\begin{array}{c}3.81^{* * *} \\
(0.05)\end{array}$ & $\begin{array}{c}3.82^{* * *} \\
(0.05)\end{array}$ & $\begin{array}{c}3.94^{* * *} \\
(0.05)\end{array}$ & $\begin{array}{c}3.94^{* * *} \\
(0.05)\end{array}$ & $\begin{array}{c}3.88^{* * *} \\
(0.05)\end{array}$ & $\begin{array}{c}4.04^{* * *} \\
(0.05)\end{array}$ \\
\hline Observations & 12,815 & 12,528 & 13,642 & 15,886 & 15,530 & 15,875 & 16,151 & 18,373 & 18,491 & 22,071 & 22,142 & 21,557 & 24,820 & 23,684 & 25,435 \\
\hline R-squared & 0.17 & 0.17 & 0.18 & 0.18 & 0.16 & 0.15 & 0.14 & 0.13 & 0.15 & 0.16 & 0.16 & 0.16 & 0.17 & 0.15 & 0.16 \\
\hline
\end{tabular}

Note: standard errors in parentheses. ${ }^{*} p<0.1,{ }^{* *} p<0.05,{ }^{* * *} p<0.01$.

Source: authors' compilation based on data from ENAHO. 
Table A6: Log earnings OLS: male population with controls

\begin{tabular}{|c|c|c|c|c|c|c|c|c|c|c|c|c|c|c|c|}
\hline & 2004 & 2005 & 2006 & 2007 & 2008 & 2009 & 2010 & 2011 & 2012 & 2013 & 2014 & 2015 & 2016 & 2017 & 2018 \\
\hline \multicolumn{16}{|c|}{ Education level (base: no schooling) } \\
\hline Primary & $\begin{array}{c}0.54^{* * *} \\
(0.05)\end{array}$ & $\begin{array}{c}0.41^{* * *} \\
(0.05)\end{array}$ & $\begin{array}{c}0.52^{* * *} \\
(0.05)\end{array}$ & $\begin{array}{c}0.40^{* * *} \\
(0.06)\end{array}$ & $\begin{array}{c}0.40^{* * *} \\
(0.06)\end{array}$ & $\begin{array}{c}0.28^{* * *} \\
(0.06)\end{array}$ & $\begin{array}{c}0.31^{* * *} \\
(0.06)\end{array}$ & $\begin{array}{c}0.33^{* * *} \\
(0.06)\end{array}$ & $\begin{array}{c}0.38^{* * *} \\
(0.07)\end{array}$ & $\begin{array}{c}0.30^{* * *} \\
(0.07)\end{array}$ & $\begin{array}{c}0.34^{* * *} \\
(0.06)\end{array}$ & $\begin{array}{c}0.53^{* * *} \\
(0.07)\end{array}$ & $\begin{array}{c}0.31^{* * *} \\
(0.07)\end{array}$ & $\begin{array}{c}0.24^{* * *} \\
(0.05)\end{array}$ & $\begin{array}{c}0.40^{* * *} \\
(0.07)\end{array}$ \\
\hline Secondary & $\begin{array}{c}0.92^{* * *} \\
(0.05)\end{array}$ & $\begin{array}{c}0.84^{* * *} \\
(0.05)\end{array}$ & $\begin{array}{c}0.98^{* * *} \\
(0.05)\end{array}$ & $\begin{array}{c}0.79^{* * *} \\
(0.06)\end{array}$ & $\begin{array}{c}0.79^{* * *} \\
(0.06)\end{array}$ & $\begin{array}{c}0.62^{* * *} \\
(0.06)\end{array}$ & $\begin{array}{c}0.68^{* * *} \\
(0.06)\end{array}$ & $\begin{array}{c}0.72^{* * *} \\
(0.06)\end{array}$ & $\begin{array}{c}0.75^{* * *} \\
(0.07)\end{array}$ & $\begin{array}{c}0.67^{* * *} \\
(0.07)\end{array}$ & $\begin{array}{c}0.74^{* * *} \\
(0.06)\end{array}$ & $\begin{array}{c}0.91^{* * *} \\
(0.07)\end{array}$ & $\begin{array}{c}0.71^{* * *} \\
(0.07)\end{array}$ & $\begin{array}{c}0.67^{* * *} \\
(0.05)\end{array}$ & $\begin{array}{c}0.76^{* * * *} \\
(0.07)\end{array}$ \\
\hline Tertiary & $\begin{array}{c}1.44^{* * *} \\
(0.05)\end{array}$ & $\begin{array}{c}1.34^{* * *} \\
(0.05)\end{array}$ & $\begin{array}{c}1.51^{* * *} \\
(0.05)\end{array}$ & $\begin{array}{c}1.35^{* * *} \\
(0.06)\end{array}$ & $\begin{array}{c}1.30^{* * *} \\
(0.06)\end{array}$ & $\begin{array}{c}1.12^{* * *} \\
(0.06)\end{array}$ & $\begin{array}{c}1.11^{* * *} \\
(0.06)\end{array}$ & $\begin{array}{c}1.14^{* * *} \\
(0.06)\end{array}$ & $\begin{array}{c}1.18^{* * *} \\
(0.07)\end{array}$ & $\begin{array}{c}1.12^{* * *} \\
(0.07)\end{array}$ & $\begin{array}{c}1.18^{* * *} \\
(0.06)\end{array}$ & $\begin{array}{c}1.33^{* * *} \\
(0.07)\end{array}$ & $\begin{array}{c}1.16^{* * *} \\
(0.07)\end{array}$ & $\begin{array}{c}1.10^{* * * *} \\
(0.05)\end{array}$ & $\begin{array}{c}1.21^{* * * *} \\
(0.07)\end{array}$ \\
\hline \multicolumn{16}{|c|}{ Age group (base: 25-44) } \\
\hline $15-24$ & $\begin{array}{c}-0.64^{* * *} \\
(0.02)\end{array}$ & $\begin{array}{c}-0.58^{* * * *} \\
(0.02)\end{array}$ & $\begin{array}{c}-0.61^{* * *} \\
(0.02)\end{array}$ & $\begin{array}{c}-0.67^{* * *} \\
(0.02)\end{array}$ & $\begin{array}{c}-0.62^{* * *} \\
(0.02)\end{array}$ & $\begin{array}{c}-0.62^{* * *} \\
(0.02)\end{array}$ & $\begin{array}{c}-0.67^{* * *} \\
(0.02)\end{array}$ & $\begin{array}{c}-0.62^{* * *} \\
(0.02)\end{array}$ & $\begin{array}{c}-0.59^{* * *} \\
(0.02)\end{array}$ & $\begin{array}{c}-0.57^{* * *} \\
(0.02)\end{array}$ & $\begin{array}{c}-0.59^{* * *} \\
(0.02)\end{array}$ & $\begin{array}{c}-0.54^{* * *} \\
(0.02)\end{array}$ & $\begin{array}{c}-0.56^{* * *} \\
(0.02)\end{array}$ & $\begin{array}{c}-0.56^{* * *} \\
(0.02)\end{array}$ & $\begin{array}{c}-0.58^{* * *} \\
(0.02)\end{array}$ \\
\hline $45-+64$ & $\begin{array}{c}0.12^{* * *} \\
(0.02)\end{array}$ & $\begin{array}{c}0.09^{* * *} \\
(0.02)\end{array}$ & $\begin{array}{c}0.18^{* * *} \\
(0.02)\end{array}$ & $\begin{array}{c}0.11^{* * *} \\
(0.02)\end{array}$ & $\begin{array}{c}0.11^{* * *} \\
(0.02)\end{array}$ & $\begin{array}{c}0.09^{* * *} \\
(0.02)\end{array}$ & $\begin{array}{c}0.06^{* * *} \\
(0.02)\end{array}$ & $\begin{array}{c}0.06^{* * *} \\
(0.02)\end{array}$ & $\begin{array}{c}0.08^{* * *} \\
(0.02)\end{array}$ & $\begin{array}{c}0.07^{* * *} \\
(0.01)\end{array}$ & $\begin{array}{c}0.06^{* * *} \\
(0.01)\end{array}$ & $\begin{array}{c}0.05^{* * *} \\
(0.01)\end{array}$ & $\begin{array}{c}0.06^{* * *} \\
(0.01)\end{array}$ & $\begin{array}{l}0.03^{* *} \\
(0.01)\end{array}$ & $\begin{array}{c}0.06^{* * *} \\
(0.01)\end{array}$ \\
\hline \multicolumn{16}{|c|}{ Dominio (base: Costa Sur) } \\
\hline Costa Norte & $\begin{array}{c}-0.15^{* * *} \\
(0.04)\end{array}$ & $\begin{array}{c}-0.14^{* * *} \\
(0.04)\end{array}$ & $\begin{array}{c}-0.15^{* * *} \\
(0.04)\end{array}$ & $\begin{array}{c}-0.14^{* * *} \\
(0.04)\end{array}$ & $\begin{array}{c}-0.27^{* * *} \\
(0.04)\end{array}$ & $\begin{array}{c}-0.09^{* *} \\
(0.04)\end{array}$ & $\begin{array}{c}-0.27^{* * *} \\
(0.04)\end{array}$ & $\begin{array}{c}-0.18^{* * *} \\
(0.03)\end{array}$ & $\begin{array}{c}-0.20^{* * *} \\
(0.03)\end{array}$ & $\begin{array}{c}-0.20^{* * *} \\
(0.03)\end{array}$ & $\begin{array}{c}-0.19^{* * *} \\
(0.03)\end{array}$ & $\begin{array}{c}-0.18^{* * *} \\
(0.03)\end{array}$ & $\begin{array}{c}-0.13^{* * *} \\
(0.02)\end{array}$ & $\begin{array}{c}-0.13^{* * *} \\
(0.03)\end{array}$ & $\begin{array}{c}-0.06^{* *} \\
(0.03)\end{array}$ \\
\hline Costa Centro & $\begin{array}{c}0.02 \\
(0.05)\end{array}$ & $\begin{array}{c}0.01 \\
(0.04)\end{array}$ & $\begin{array}{c}0.03 \\
(0.04)\end{array}$ & $\begin{array}{l}-0.04 \\
(0.04)\end{array}$ & $\begin{array}{c}-0.12^{* * *} \\
(0.04)\end{array}$ & $\begin{array}{c}-0.09^{* *} \\
(0.04)\end{array}$ & $\begin{array}{c}-0.19^{* * *} \\
(0.04)\end{array}$ & $\begin{array}{c}-0.10^{* *} \\
(0.04)\end{array}$ & $\begin{array}{c}-0.10^{* * *} \\
(0.04)\end{array}$ & $\begin{array}{c}-0.11^{* * *} \\
(0.03)\end{array}$ & $\begin{array}{c}-0.12^{* * *} \\
(0.03)\end{array}$ & $\begin{array}{c}-0.09^{* * *} \\
(0.03)\end{array}$ & $\begin{array}{c}-0.06^{* *} \\
(0.02)\end{array}$ & $\begin{array}{l}-0.03 \\
(0.03)\end{array}$ & $\begin{array}{l}-0.01 \\
(0.03)\end{array}$ \\
\hline Sierra Norte & $\begin{array}{c}-0.49^{* * *} \\
(0.05)\end{array}$ & $\begin{array}{c}-0.43^{* * *} \\
(0.05)\end{array}$ & $\begin{array}{c}-0.47^{* * *} \\
(0.05)\end{array}$ & $\begin{array}{c}-0.55^{* * *} \\
(0.05)\end{array}$ & $\begin{array}{c}-0.63^{* * *} \\
(0.05)\end{array}$ & $\begin{array}{c}-0.39^{* * *} \\
(0.05)\end{array}$ & $\begin{array}{c}-0.53^{* * *} \\
(0.05)\end{array}$ & $\begin{array}{c}-0.51^{* * *} \\
(0.04)\end{array}$ & $\begin{array}{c}-0.60^{* * *} \\
(0.04)\end{array}$ & $\begin{array}{c}-0.53^{* * *} \\
(0.04)\end{array}$ & $\begin{array}{c}-0.56^{* * *} \\
(0.04)\end{array}$ & $\begin{array}{c}-0.58^{* * *} \\
(0.04)\end{array}$ & $\begin{array}{c}-0.54^{* * *} \\
(0.03)\end{array}$ & $\begin{array}{c}-0.51^{* * *} \\
(0.04)\end{array}$ & $\begin{array}{c}-0.48^{* * *} \\
(0.03)\end{array}$ \\
\hline Sierra Centro & $\begin{array}{c}-0.44^{* * * *} \\
(0.04)\end{array}$ & $\begin{array}{c}-0.46^{* * *} \\
(0.04)\end{array}$ & $\begin{array}{c}-0.55^{* * *} \\
(0.04)\end{array}$ & $\begin{array}{c}-0.48^{* * *} \\
(0.04)\end{array}$ & $\begin{array}{c}-0.52^{* * *} \\
(0.04)\end{array}$ & $\begin{array}{c}-0.37^{* * *} \\
(0.04)\end{array}$ & $\begin{array}{c}-0.47^{* * *} \\
(0.04)\end{array}$ & $\begin{array}{c}-0.44^{* * *} \\
(0.03)\end{array}$ & $\begin{array}{c}-0.47^{* * *} \\
(0.03)\end{array}$ & $\begin{array}{c}-0.46^{* * *} \\
(0.03)\end{array}$ & $\begin{array}{c}-0.46^{* * *} \\
(0.03)\end{array}$ & $\begin{array}{c}-0.43^{* * *} \\
(0.03)\end{array}$ & $\begin{array}{c}-0.40^{* * *} \\
(0.03)\end{array}$ & $\begin{array}{c}-0.41^{* * *} \\
(0.03)\end{array}$ & $\begin{array}{c}-0.39^{* * *} \\
(0.03)\end{array}$ \\
\hline Sierra Sur & $\begin{array}{c}-0.42^{* * *} \\
(0.04)\end{array}$ & $\begin{array}{c}-0.45^{* * *} \\
(0.04)\end{array}$ & $\begin{array}{c}-0.43^{* * *} \\
(0.04)\end{array}$ & $\begin{array}{c}-0.41^{* * *} \\
(0.04)\end{array}$ & $\begin{array}{c}-0.51^{* * *} \\
(0.04)\end{array}$ & $\begin{array}{c}-0.36^{* * *} \\
(0.04)\end{array}$ & $\begin{array}{c}-0.44^{* * *} \\
(0.04)\end{array}$ & $\begin{array}{c}-0.33^{* * *} \\
(0.04)\end{array}$ & $\begin{array}{c}-0.33^{* * *} \\
(0.03)\end{array}$ & $\begin{array}{c}-0.27^{* * *} \\
(0.03)\end{array}$ & $\begin{array}{c}-0.28^{* * *} \\
(0.03)\end{array}$ & $\begin{array}{c}-0.28^{* * *} \\
(0.03)\end{array}$ & $\begin{array}{c}-0.25^{* * *} \\
(0.03)\end{array}$ & $\begin{array}{c}-0.29^{* * *} \\
(0.03)\end{array}$ & $\begin{array}{c}-0.23^{* * *} \\
(0.03)\end{array}$ \\
\hline Selva & $\begin{array}{c}-0.33^{* * *} \\
(0.04)\end{array}$ & $\begin{array}{c}-0.33^{* * *} \\
(0.04)\end{array}$ & $\begin{array}{c}-0.30^{* * *} \\
(0.04)\end{array}$ & $\begin{array}{c}-0.24^{* * *} \\
(0.04)\end{array}$ & $\begin{array}{c}-0.34^{* * *} \\
(0.04)\end{array}$ & $\begin{array}{c}-0.30^{* * *} \\
(0.04)\end{array}$ & $\begin{array}{c}-0.36^{* * *} \\
(0.04)\end{array}$ & $\begin{array}{c}-0.23^{* * *} \\
(0.03)\end{array}$ & $\begin{array}{c}-0.30^{* * *} \\
(0.03)\end{array}$ & $\begin{array}{c}-0.32^{* * *} \\
(0.03)\end{array}$ & $\begin{array}{c}-0.34^{* * *} \\
(0.03)\end{array}$ & $\begin{array}{c}-0.31^{* * *} \\
(0.03)\end{array}$ & $\begin{array}{c}-0.31^{* * *} \\
(0.02)\end{array}$ & $\begin{array}{c}-0.31^{* * *} \\
(0.03)\end{array}$ & $\begin{array}{c}-0.28^{* * *} \\
(0.03)\end{array}$ \\
\hline Lima Metropolitana & $\begin{array}{c}0.30^{* * *} \\
(0.04)\end{array}$ & $\begin{array}{c}0.30^{* * * *} \\
(0.04)\end{array}$ & $\begin{array}{c}0.25^{* * *} \\
(0.04)\end{array}$ & $\begin{array}{c}0.24^{* * *} \\
(0.04)\end{array}$ & $\begin{array}{c}0.13^{* * *} \\
(0.04)\end{array}$ & $\begin{array}{c}0.21^{* * *} \\
(0.04)\end{array}$ & $\begin{array}{c}0.02 \\
(0.04)\end{array}$ & $\begin{array}{c}0.10^{* * * *} \\
(0.03)\end{array}$ & $\begin{array}{c}0.09^{* * *} \\
(0.03)\end{array}$ & $\begin{array}{c}0.09^{* * *} \\
(0.03)\end{array}$ & $\begin{array}{c}0.12^{* * *} \\
(0.03)\end{array}$ & $\begin{array}{c}0.14^{* * *} \\
(0.03)\end{array}$ & $\begin{array}{c}0.21^{* * *} \\
(0.02)\end{array}$ & $\begin{array}{c}0.18^{* * *} \\
(0.03)\end{array}$ & $\begin{array}{c}0.19^{* * *} \\
(0.03)\end{array}$ \\
\hline Constant & $\begin{array}{c}4.13^{* * *} \\
(0.06)\end{array}$ & $\begin{array}{c}4.21^{* * *} \\
(0.06)\end{array}$ & $\begin{array}{c}4.13^{* * *} \\
(0.06)\end{array}$ & $\begin{array}{c}4.36^{* * *} \\
(0.07)\end{array}$ & $\begin{array}{c}4.53^{* * *} \\
(0.07)\end{array}$ & $\begin{array}{c}4.66^{* * *} \\
(0.07)\end{array}$ & $\begin{array}{c}4.82^{* * * *} \\
(0.07)\end{array}$ & $\begin{array}{c}4.72^{* * *} \\
(0.07)\end{array}$ & $\begin{array}{c}4.74^{* * *} \\
(0.07)\end{array}$ & $\begin{array}{c}4.82^{* * *} \\
(0.07)\end{array}$ & $\begin{array}{c}4.79^{* * *} \\
(0.07)\end{array}$ & $\begin{array}{c}4.60^{* * *} \\
(0.08)\end{array}$ & $\begin{array}{c}4.75^{* * *} \\
(0.07)\end{array}$ & $\begin{array}{c}4.82^{* * *} \\
(0.06)\end{array}$ & $\begin{array}{c}4.67^{* * *} \\
(0.07)\end{array}$ \\
\hline Observations & 19,370 & 19,074 & 20,351 & 21,912 & 21,219 & 21,557 & 21,193 & 24,146 & 24,009 & 28,377 & 28,101 & 28,376 & 31,183 & 29,699 & 31,479 \\
\hline R-squared & 0.32 & 0.31 & 0.33 & 0.31 & 0.28 & 0.24 & 0.22 & 0.22 & 0.23 & 0.22 & 0.25 & 0.24 & 0.25 & 0.25 & 0.24 \\
\hline
\end{tabular}

Note: standard errors in parentheses. ${ }^{*} p<0.1,{ }^{* *} p<0.05,{ }^{* * *} p<0.01$.

Source: authors' compilation based on data from ENAHO. 
Table A7: Log earnings OLS: female population with controls

\begin{tabular}{|c|c|c|c|c|c|c|c|c|c|c|c|c|c|c|c|}
\hline & 2004 & 2005 & 2006 & 2007 & 2008 & 2009 & 2010 & 2011 & 2012 & 2013 & 2014 & 2015 & 2016 & 2017 & 2018 \\
\hline \multicolumn{16}{|c|}{ Education level (base: no schooling) } \\
\hline Primary & $\begin{array}{c}0.37^{* * *} \\
(0.05)\end{array}$ & $\begin{array}{c}0.49^{* * *} \\
(0.05)\end{array}$ & $\begin{array}{c}0.43^{* * *} \\
(0.05)\end{array}$ & $\begin{array}{c}0.37^{* * *} \\
(0.05)\end{array}$ & $\begin{array}{c}0.41^{* * *} \\
(0.05)\end{array}$ & $\begin{array}{c}0.45^{* * *} \\
(0.05)\end{array}$ & $\begin{array}{c}0.31^{* * *} \\
(0.05)\end{array}$ & $\begin{array}{c}0.38^{* * *} \\
(0.05)\end{array}$ & $\begin{array}{c}0.48^{* * *} \\
(0.06)\end{array}$ & $\begin{array}{c}0.37^{* * *} \\
(0.05)\end{array}$ & $\begin{array}{c}0.41^{* * *} \\
(0.05)\end{array}$ & $\begin{array}{c}0.29^{* * *} \\
(0.05)\end{array}$ & $\begin{array}{c}0.26^{* * *} \\
(0.05)\end{array}$ & $\begin{array}{c}0.35^{* * *} \\
(0.05)\end{array}$ & $\begin{array}{c}0.22^{* * *} \\
(0.05)\end{array}$ \\
\hline Secondary & $\begin{array}{c}0.70^{* * *} \\
(0.05)\end{array}$ & $\begin{array}{c}0.84^{* * *} \\
(0.05)\end{array}$ & $\begin{array}{c}0.76^{* * *} \\
(0.05)\end{array}$ & $\begin{array}{c}0.81^{* * *} \\
(0.05)\end{array}$ & $\begin{array}{c}0.78^{* * *} \\
(0.06)\end{array}$ & $\begin{array}{c}0.81^{* * *} \\
(0.05)\end{array}$ & $\begin{array}{c}0.65^{* * *} \\
(0.06)\end{array}$ & $\begin{array}{c}0.70^{* * *} \\
(0.05)\end{array}$ & $\begin{array}{c}0.80^{* * *} \\
(0.06)\end{array}$ & $\begin{array}{c}0.73^{* * *} \\
(0.05)\end{array}$ & $\begin{array}{c}0.74^{* * *} \\
(0.05)\end{array}$ & $\begin{array}{c}0.63^{* * *} \\
(0.05)\end{array}$ & $\begin{array}{c}0.60^{* * *} \\
(0.05)\end{array}$ & $\begin{array}{c}0.71^{* * *} \\
(0.05)\end{array}$ & $\begin{array}{c}0.63^{* * *} \\
(0.05)\end{array}$ \\
\hline Tertiary & $\begin{array}{c}1.30^{* * *} \\
(0.05)\end{array}$ & $\begin{array}{c}1.41^{* * *} \\
(0.06)\end{array}$ & $\begin{array}{c}1.43^{* * *} \\
(0.06)\end{array}$ & $\begin{array}{c}1.50^{* * *} \\
(0.05)\end{array}$ & $\begin{array}{c}1.44^{* * *} \\
(0.06)\end{array}$ & $\begin{array}{c}1.47^{* * *} \\
(0.05)\end{array}$ & $\begin{array}{c}1.28^{* * *} \\
(0.06)\end{array}$ & $\begin{array}{c}1.31^{* * *} \\
(0.05)\end{array}$ & $\begin{array}{c}1.43^{* * *} \\
(0.06)\end{array}$ & $\begin{array}{c}1.38^{* * *} \\
(0.05)\end{array}$ & $\begin{array}{c}1.39^{* * *} \\
(0.05)\end{array}$ & $\begin{array}{c}1.29^{* * *} \\
(0.05)\end{array}$ & $\begin{array}{c}1.28^{* * *} \\
(0.05)\end{array}$ & $\begin{array}{c}1.33^{* * *} \\
(0.05)\end{array}$ & $\begin{array}{c}1.28^{* * *} \\
(0.05)\end{array}$ \\
\hline \multicolumn{16}{|c|}{ Age group (base: 25-44) } \\
\hline $15-24$ & $\begin{array}{c}-0.38^{* * *} \\
(0.03)\end{array}$ & $\begin{array}{c}-0.34^{* * * *} \\
(0.03)\end{array}$ & $\begin{array}{c}-0.33^{* * *} \\
(0.03)\end{array}$ & $\begin{array}{c}-0.40^{* * *} \\
(0.03)\end{array}$ & $\begin{array}{c}-0.35^{* * *} \\
(0.03)\end{array}$ & $\begin{array}{c}-0.39^{* * *} \\
(0.03)\end{array}$ & $\begin{array}{c}-0.42^{* * *} \\
(0.03)\end{array}$ & $\begin{array}{c}-0.38^{* * *} \\
(0.03)\end{array}$ & $\begin{array}{c}-0.36^{* * *} \\
(0.03)\end{array}$ & $\begin{array}{c}-0.37^{* * *} \\
(0.03)\end{array}$ & $\begin{array}{c}-0.34^{* * *} \\
(0.03)\end{array}$ & $\begin{array}{c}-0.36^{* * *} \\
(0.03)\end{array}$ & $\begin{array}{c}-0.36^{* * *} \\
(0.03)\end{array}$ & $\begin{array}{c}-0.40^{* * *} \\
(0.03)\end{array}$ & $\begin{array}{c}-0.44^{* * *} \\
(0.03)\end{array}$ \\
\hline $45-64$ & $\begin{array}{c}0.03 \\
(0.03)\end{array}$ & $\begin{array}{c}0.09^{* * *} \\
(0.03)\end{array}$ & $\begin{array}{c}0.05 \\
(0.03)\end{array}$ & $\begin{array}{c}0.11^{* * *} \\
(0.03)\end{array}$ & $\begin{array}{c}0.09^{* * *} \\
(0.03)\end{array}$ & $\begin{array}{c}0.11^{* * *} \\
(0.03)\end{array}$ & $\begin{array}{l}0.06^{* *} \\
(0.03)\end{array}$ & $\begin{array}{c}0.09^{* * *} \\
(0.03)\end{array}$ & $\begin{array}{c}0.07^{* * *} \\
(0.02)\end{array}$ & $\begin{array}{c}0.07^{* * *} \\
(0.02)\end{array}$ & $\begin{array}{l}0.05^{* *} \\
(0.02)\end{array}$ & $\begin{array}{c}0.06^{* * *} \\
(0.02)\end{array}$ & $\begin{array}{l}0.05^{* *} \\
(0.02)\end{array}$ & $\begin{array}{c}0.07^{* * *} \\
(0.02)\end{array}$ & $\begin{array}{c}0.07^{* * *} \\
(0.02)\end{array}$ \\
\hline \multicolumn{16}{|c|}{ Dominio (base: Costa Sur) } \\
\hline Costa Norte & $\begin{array}{c}-0.27^{* * *} \\
(0.05)\end{array}$ & $\begin{array}{c}-0.33^{* * *} \\
(0.05)\end{array}$ & $\begin{array}{c}-0.30^{* * *} \\
(0.06)\end{array}$ & $\begin{array}{c}-0.43^{* * *} \\
(0.05)\end{array}$ & $\begin{array}{c}-0.49^{* * *} \\
(0.06)\end{array}$ & $\begin{array}{c}-0.42^{* * *} \\
(0.05)\end{array}$ & $\begin{array}{c}-0.49^{* * *} \\
(0.05)\end{array}$ & $\begin{array}{c}-0.41^{* * *} \\
(0.05)\end{array}$ & $\begin{array}{c}-0.43^{* * *} \\
(0.04)\end{array}$ & $\begin{array}{c}-0.49 * * * \\
(0.04)\end{array}$ & $\begin{array}{c}-0.47^{* * *} \\
(0.04)\end{array}$ & $\begin{array}{c}-0.41^{* * * *} \\
(0.04)\end{array}$ & $\begin{array}{c}-0.41^{* * *} \\
(0.03)\end{array}$ & $\begin{array}{c}-0.40^{* * *} \\
(0.04)\end{array}$ & $\begin{array}{c}-0.36^{* * *} \\
(0.03)\end{array}$ \\
\hline Costa Centro & $\begin{array}{l}-0.08 \\
(0.06)\end{array}$ & $\begin{array}{c}0.02 \\
(0.06)\end{array}$ & $\begin{array}{l}-0.07 \\
(0.06)\end{array}$ & $\begin{array}{c}-0.11^{* *} \\
(0.05)\end{array}$ & $\begin{array}{c}-0.14^{* *} \\
(0.06)\end{array}$ & $\begin{array}{c}-0.22^{* * *} \\
(0.05)\end{array}$ & $\begin{array}{c}-0.13^{* * *} \\
(0.05)\end{array}$ & $\begin{array}{c}-0.23^{* * *} \\
(0.05)\end{array}$ & $\begin{array}{c}-0.20^{* * *} \\
(0.04)\end{array}$ & $\begin{array}{c}-0.26^{* * *} \\
(0.04)\end{array}$ & $\begin{array}{c}-0.19^{* * *} \\
(0.05)\end{array}$ & $\begin{array}{c}-0.14^{* * *} \\
(0.04)\end{array}$ & $\begin{array}{c}-0.09^{* * *} \\
(0.03)\end{array}$ & $\begin{array}{c}-0.18^{* * *} \\
(0.04)\end{array}$ & $\begin{array}{c}-0.10^{* * * *} \\
(0.03)\end{array}$ \\
\hline Sierra Norte & $\begin{array}{c}-0.55^{* * *} \\
(0.07)\end{array}$ & $\begin{array}{c}-0.58^{* * * *} \\
(0.07)\end{array}$ & $\begin{array}{c}-0.56^{* * *} \\
(0.07)\end{array}$ & $\begin{array}{c}-0.84^{* * *} \\
(0.06)\end{array}$ & $\begin{array}{c}-0.86^{* * *} \\
(0.07)\end{array}$ & $\begin{array}{c}-0.90^{* * *} \\
(0.06)\end{array}$ & $\begin{array}{c}-0.82^{* * *} \\
(0.06)\end{array}$ & $\begin{array}{c}-0.62^{* * *} \\
(0.06)\end{array}$ & $\begin{array}{c}-0.72^{* * *} \\
(0.06)\end{array}$ & $\begin{array}{c}-0.89^{* * *} \\
(0.06)\end{array}$ & $\begin{array}{c}-0.72^{* * *} \\
(0.06)\end{array}$ & $\begin{array}{c}-0.86^{* * *} \\
(0.06)\end{array}$ & $\begin{array}{c}-0.81^{* * *} \\
(0.05)\end{array}$ & $\begin{array}{c}-0.86^{* * *} \\
(0.05)\end{array}$ & $\begin{array}{c}-0.79 * * * \\
(0.05)\end{array}$ \\
\hline Sierra Centro & $\begin{array}{c}-0.41^{* * *} \\
(0.05)\end{array}$ & $\begin{array}{c}-0.38^{* * * *} \\
(0.06)\end{array}$ & $\begin{array}{c}-0.38^{* * *} \\
(0.06)\end{array}$ & $\begin{array}{c}-0.48^{* * *} \\
(0.05)\end{array}$ & $\begin{array}{c}-0.44^{* * *} \\
(0.06)\end{array}$ & $\begin{array}{c}-0.46^{* * *} \\
(0.04)\end{array}$ & $\begin{array}{c}-0.46^{* * *} \\
(0.05)\end{array}$ & $\begin{array}{c}-0.46^{* * *} \\
(0.04)\end{array}$ & $\begin{array}{c}-0.47^{* * *} \\
(0.04)\end{array}$ & $\begin{array}{c}-0.50^{* * *} \\
(0.04)\end{array}$ & $\begin{array}{c}-0.47^{* * *} \\
(0.04)\end{array}$ & $\begin{array}{c}-0.46^{* * *} \\
(0.04)\end{array}$ & $\begin{array}{c}-0.42^{* * *} \\
(0.03)\end{array}$ & $\begin{array}{c}-0.50^{* * *} \\
(0.04)\end{array}$ & $\begin{array}{c}-0.50^{* * * *} \\
(0.04)\end{array}$ \\
\hline Sierra Sur & $\begin{array}{c}-0.35^{* * *} \\
(0.05)\end{array}$ & $\begin{array}{c}-0.37^{* * *} \\
(0.05)\end{array}$ & $\begin{array}{c}-0.33^{* * *} \\
(0.06)\end{array}$ & $\begin{array}{c}-0.42^{* * *} \\
(0.05)\end{array}$ & $\begin{array}{c}-0.41^{* * *} \\
(0.05)\end{array}$ & $\begin{array}{c}-0.34^{* * *} \\
(0.05)\end{array}$ & $\begin{array}{c}-0.35^{* * *} \\
(0.05)\end{array}$ & $\begin{array}{c}-0.30^{* * *} \\
(0.04)\end{array}$ & $\begin{array}{c}-0.32^{* * *} \\
(0.04)\end{array}$ & $\begin{array}{c}-0.33^{* * *} \\
(0.04)\end{array}$ & $\begin{array}{c}-0.20^{* * *} \\
(0.04)\end{array}$ & $\begin{array}{c}-0.29^{* * *} \\
(0.04)\end{array}$ & $\begin{array}{c}-0.22^{* * *} \\
(0.03)\end{array}$ & $\begin{array}{c}-0.30^{* * *} \\
(0.04)\end{array}$ & $\begin{array}{c}-0.30^{* * * *} \\
(0.03)\end{array}$ \\
\hline Selva & $\begin{array}{c}-0.10^{* *} \\
(0.05)\end{array}$ & $\begin{array}{c}-0.15^{* * *} \\
(0.05)\end{array}$ & $\begin{array}{c}-0.13^{* *} \\
(0.06)\end{array}$ & $\begin{array}{c}-0.18^{* * *} \\
(0.05)\end{array}$ & $\begin{array}{c}-0.20^{* * *} \\
(0.05)\end{array}$ & $\begin{array}{c}-0.23^{* * *} \\
(0.04)\end{array}$ & $\begin{array}{c}-0.31^{* * *} \\
(0.05)\end{array}$ & $\begin{array}{c}-0.22^{* * *} \\
(0.04)\end{array}$ & $\begin{array}{c}-0.24^{* * *} \\
(0.04)\end{array}$ & $\begin{array}{c}-0.31^{* * *} \\
(0.04)\end{array}$ & $\begin{array}{c}-0.27^{* * *} \\
(0.04)\end{array}$ & $\begin{array}{c}-0.27^{* * *} \\
(0.04)\end{array}$ & $\begin{array}{c}-0.29^{* * *} \\
(0.03)\end{array}$ & $\begin{array}{c}-0.26^{* * *} \\
(0.03)\end{array}$ & $\begin{array}{c}-0.27^{* * *} \\
(0.03)\end{array}$ \\
\hline Lima Metropolitana & $\begin{array}{c}0.43^{* * *} \\
(0.05)\end{array}$ & $\begin{array}{c}0.41^{* * *} \\
(0.05)\end{array}$ & $\begin{array}{c}0.36^{* * *} \\
(0.05)\end{array}$ & $\begin{array}{c}0.16^{* * *} \\
(0.05)\end{array}$ & $\begin{array}{c}0.23^{* * *} \\
(0.05)\end{array}$ & $\begin{array}{c}0.12^{* * * *} \\
(0.04)\end{array}$ & $\begin{array}{c}0.07 \\
(0.04)\end{array}$ & $\begin{array}{c}0.14^{* * *} \\
(0.04)\end{array}$ & $\begin{array}{c}0.13^{* * *} \\
(0.04)\end{array}$ & $\begin{array}{c}0.14^{* * *} \\
(0.04)\end{array}$ & $\begin{array}{c}0.20^{* * *} \\
(0.04)\end{array}$ & $\begin{array}{c}0.23^{* * *} \\
(0.04)\end{array}$ & $\begin{array}{c}0.25^{* * *} \\
(0.03)\end{array}$ & $\begin{array}{c}0.17^{* * *} \\
(0.03)\end{array}$ & $\begin{array}{c}0.12^{* * *} \\
(0.03)\end{array}$ \\
\hline Constant & $\begin{array}{c}3.79^{* * *} \\
(0.06)\end{array}$ & $\begin{array}{c}3.64^{* * *} \\
(0.07)\end{array}$ & $\begin{array}{c}3.76^{* * *} \\
(0.07)\end{array}$ & $\begin{array}{c}3.83^{* * *} \\
(0.07)\end{array}$ & $\begin{array}{c}3.83^{* * *} \\
(0.07)\end{array}$ & $\begin{array}{c}3.90^{* * *} \\
(0.06)\end{array}$ & $\begin{array}{c}4.13^{* * *} \\
(0.07)\end{array}$ & $\begin{array}{c}4.08^{* * *} \\
(0.06)\end{array}$ & $\begin{array}{c}4.05^{* * *} \\
(0.06)\end{array}$ & $\begin{array}{c}4.17^{* * *} \\
(0.06)\end{array}$ & $\begin{array}{c}4.13^{* * *} \\
(0.06)\end{array}$ & $\begin{array}{c}4.26^{* * *} \\
(0.06)\end{array}$ & $\begin{array}{c}4.25^{* * *} \\
(0.05)\end{array}$ & $\begin{array}{c}4.23^{* * *} \\
(0.05)\end{array}$ & $\begin{array}{c}4.34^{* * *} \\
(0.05)\end{array}$ \\
\hline Observations & 12,815 & 12,528 & 13,642 & 15,886 & 15,530 & 15,875 & 16,151 & 18,373 & 18,491 & 22,071 & 22,142 & 21,557 & 24,820 & 23,684 & 25,435 \\
\hline R-squared & 0.27 & 0.27 & 0.27 & 0.26 & 0.24 & 0.22 & 0.20 & 0.19 & 0.21 & 0.24 & 0.24 & 0.25 & 0.26 & 0.24 & 0.23 \\
\hline
\end{tabular}

Note: standard errors in parentheses. ${ }^{*} p<0.1,{ }^{* *} p<0.05,{ }^{* * *} p<0.01$.

Source: authors' compilation based on data from ENAHO. 
Table A8: Log earnings OLS: male population with controls and ISCO-88 two-digit fixed effects

\begin{tabular}{|c|c|c|c|c|c|c|c|c|c|c|c|c|c|c|c|}
\hline & 2004 & 2005 & 2006 & 2007 & 2008 & 2009 & 2010 & 2011 & 2012 & 2013 & 2014 & 2015 & 2016 & 2017 & 2018 \\
\hline \multicolumn{16}{|c|}{ Education level (base: no schooling) } \\
\hline Primary & $\begin{array}{c}0.41^{* * *} \\
(0.05)\end{array}$ & $\begin{array}{c}0.30^{* * *} \\
(0.05)\end{array}$ & $\begin{array}{c}0.40^{* * *} \\
(0.05)\end{array}$ & $\begin{array}{c}0.33^{* * *} \\
(0.06)\end{array}$ & $\begin{array}{c}0.32^{* * *} \\
(0.06)\end{array}$ & $\begin{array}{c}0.19^{* * *} \\
(0.06)\end{array}$ & $\begin{array}{c}0.24^{* * *} \\
(0.06)\end{array}$ & $\begin{array}{c}0.24^{* * *} \\
(0.06)\end{array}$ & $\begin{array}{c}0.30^{* * *} \\
(0.06)\end{array}$ & $\begin{array}{c}0.25^{* * *} \\
(0.06)\end{array}$ & $\begin{array}{c}0.28^{* * *} \\
(0.06)\end{array}$ & $\begin{array}{c}0.44^{* * *} \\
(0.07)\end{array}$ & $\begin{array}{c}0.27^{* * *} \\
(0.07)\end{array}$ & $\begin{array}{c}0.24^{* * *} \\
(0.05)\end{array}$ & $\begin{array}{c}0.35^{* * *} \\
(0.06)\end{array}$ \\
\hline Secondary & $\begin{array}{c}0.56^{* * *} \\
(0.05)\end{array}$ & $\begin{array}{c}0.48^{* * *} \\
(0.05)\end{array}$ & $\begin{array}{c}0.59^{* * *} \\
(0.05)\end{array}$ & $\begin{array}{c}0.49^{* * *} \\
(0.06)\end{array}$ & $\begin{array}{c}0.51^{* * *} \\
(0.06)\end{array}$ & $\begin{array}{c}0.32^{* * *} \\
(0.06)\end{array}$ & $\begin{array}{c}0.39^{* * *} \\
(0.06)\end{array}$ & $\begin{array}{c}0.44^{* * *} \\
(0.06)\end{array}$ & $\begin{array}{c}0.44^{* * *} \\
(0.06)\end{array}$ & $\begin{array}{c}0.39^{* * *} \\
(0.06)\end{array}$ & $\begin{array}{c}0.44^{* * *} \\
(0.06)\end{array}$ & $\begin{array}{c}0.60^{* * *} \\
(0.07)\end{array}$ & $\begin{array}{c}0.45^{* * *} \\
(0.07)\end{array}$ & $\begin{array}{c}0.43^{* * *} \\
(0.05)\end{array}$ & $\begin{array}{c}0.51^{* * *} \\
(0.06)\end{array}$ \\
\hline Tertiary & $\begin{array}{c}0.67^{* * *} \\
(0.06)\end{array}$ & $\begin{array}{c}0.61^{* * *} \\
(0.05)\end{array}$ & $\begin{array}{c}0.75^{* * *} \\
(0.05)\end{array}$ & $\begin{array}{c}0.67^{* * *} \\
(0.06)\end{array}$ & $\begin{array}{c}0.65^{* * *} \\
(0.06)\end{array}$ & $\begin{array}{c}0.44^{* * *} \\
(0.07)\end{array}$ & $\begin{array}{c}0.50^{* * *} \\
(0.06)\end{array}$ & $\begin{array}{c}0.56^{* * *} \\
(0.06)\end{array}$ & $\begin{array}{c}0.54^{* * *} \\
(0.07)\end{array}$ & $\begin{array}{c}0.51^{* * *} \\
(0.06)\end{array}$ & $\begin{array}{c}0.56^{* * *} \\
(0.06)\end{array}$ & $\begin{array}{c}0.70^{* * *} \\
(0.07)\end{array}$ & $\begin{array}{c}0.58^{* * *} \\
(0.07)\end{array}$ & $\begin{array}{c}0.53^{* * *} \\
(0.05)\end{array}$ & $\begin{array}{c}0.62^{* * *} \\
(0.06)\end{array}$ \\
\hline \multicolumn{16}{|c|}{ Age group (base: $25-44$ ) } \\
\hline $15-24$ & $\begin{array}{c}-0.61^{* * *} \\
(0.02)\end{array}$ & $\begin{array}{c}-0.57^{* * *} \\
(0.02)\end{array}$ & $\begin{array}{c}-0.58^{* * *} \\
(0.02)\end{array}$ & $\begin{array}{c}-0.64^{* * *} \\
(0.02)\end{array}$ & $\begin{array}{c}-0.60^{* * *} \\
(0.02)\end{array}$ & $\begin{array}{c}-0.59^{* * *} \\
(0.02)\end{array}$ & $\begin{array}{c}-0.65^{* * *} \\
(0.02)\end{array}$ & $\begin{array}{c}-0.62^{* * *} \\
(0.02)\end{array}$ & $\begin{array}{c}-0.59^{* * *} \\
(0.02)\end{array}$ & $\begin{array}{c}-0.56^{* * *} \\
(0.02)\end{array}$ & $\begin{array}{c}-0.58^{* * *} \\
(0.02)\end{array}$ & $\begin{array}{c}-0.53^{* * *} \\
(0.02)\end{array}$ & $\begin{array}{c}-0.56^{* * *} \\
(0.02)\end{array}$ & $\begin{array}{c}-0.56^{* * *} \\
(0.02)\end{array}$ & $\begin{array}{c}-0.58^{* * *} \\
(0.02)\end{array}$ \\
\hline $45-64$ & $\begin{array}{c}0.08^{* * *} \\
(0.02)\end{array}$ & $\begin{array}{c}0.06^{* * *} \\
(0.02)\end{array}$ & $\begin{array}{c}0.14^{* * *} \\
(0.02)\end{array}$ & $\begin{array}{c}0.09^{* * *} \\
(0.02)\end{array}$ & $\begin{array}{c}0.10^{* * *} \\
(0.02)\end{array}$ & $\begin{array}{c}0.06^{* * *} \\
(0.02)\end{array}$ & $\begin{array}{l}0.03^{*} \\
(0.02)\end{array}$ & $\begin{array}{c}0.05^{* * *} \\
(0.02)\end{array}$ & $\begin{array}{c}0.07^{* * *} \\
(0.02)\end{array}$ & $\begin{array}{c}0.05^{* * *} \\
(0.01)\end{array}$ & $\begin{array}{c}0.05^{* * *} \\
(0.01)\end{array}$ & $\begin{array}{c}0.05^{* * *} \\
(0.01)\end{array}$ & $\begin{array}{c}0.05^{* * *} \\
(0.01)\end{array}$ & $\begin{array}{c}0.03^{* * *} \\
(0.01)\end{array}$ & $\begin{array}{c}0.05^{* * *} \\
(0.01)\end{array}$ \\
\hline \multicolumn{16}{|c|}{ Dominio (base: Costa Sur) } \\
\hline Costa Norte & $\begin{array}{c}-0.15^{* * *} \\
(0.04)\end{array}$ & $\begin{array}{c}-0.14^{* * *} \\
(0.04)\end{array}$ & $\begin{array}{c}-0.13^{* * *} \\
(0.04)\end{array}$ & $\begin{array}{c}-0.18^{* * *} \\
(0.04)\end{array}$ & $\begin{array}{c}-0.28^{* * *} \\
(0.04)\end{array}$ & $\begin{array}{c}-0.11^{* * *} \\
(0.04)\end{array}$ & $\begin{array}{c}-0.27^{* * *} \\
(0.04)\end{array}$ & $\begin{array}{c}-0.17^{* * *} \\
(0.03)\end{array}$ & $\begin{array}{c}-0.19^{* * *} \\
(0.03)\end{array}$ & $\begin{array}{c}-0.19^{* * *} \\
(0.03)\end{array}$ & $\begin{array}{c}-0.18^{* * *} \\
(0.03)\end{array}$ & $\begin{array}{c}-0.17^{* * *} \\
(0.03)\end{array}$ & $\begin{array}{c}-0.13^{* * *} \\
(0.02)\end{array}$ & $\begin{array}{c}-0.11^{* * *} \\
(0.03)\end{array}$ & $\begin{array}{l}-0.04 \\
(0.03)\end{array}$ \\
\hline Costa Centro & $\begin{array}{c}0.02 \\
(0.05)\end{array}$ & $\begin{array}{l}-0.00 \\
(0.04)\end{array}$ & $\begin{array}{c}0.06 \\
(0.04)\end{array}$ & $\begin{array}{l}-0.07 \\
(0.04)\end{array}$ & $\begin{array}{c}-0.11^{* * *} \\
(0.04)\end{array}$ & $\begin{array}{c}-0.08^{* *} \\
(0.04)\end{array}$ & $\begin{array}{c}-0.16^{* * *} \\
(0.04)\end{array}$ & $\begin{array}{c}-0.09^{* *} \\
(0.04)\end{array}$ & $\begin{array}{c}-0.08^{* *} \\
(0.04)\end{array}$ & $\begin{array}{c}-0.08^{* *} \\
(0.03)\end{array}$ & $\begin{array}{c}-0.10^{* * *} \\
(0.03)\end{array}$ & $\begin{array}{c}-0.08^{* *} \\
(0.03)\end{array}$ & $\begin{array}{c}-0.04^{*} \\
(0.02)\end{array}$ & $\begin{array}{c}0.01 \\
(0.03)\end{array}$ & $\begin{array}{c}0.01 \\
(0.03)\end{array}$ \\
\hline Sierra Norte & $\begin{array}{c}-0.33^{* * *} \\
(0.05)\end{array}$ & $\begin{array}{c}-0.32^{* * *} \\
(0.04)\end{array}$ & $\begin{array}{c}-0.31^{* * *} \\
(0.04)\end{array}$ & $\begin{array}{c}-0.46^{* * *} \\
(0.04)\end{array}$ & $\begin{array}{c}-0.51^{* * *} \\
(0.05)\end{array}$ & $\begin{array}{c}-0.29^{* * *} \\
(0.04)\end{array}$ & $\begin{array}{c}-0.43^{* * *} \\
(0.05)\end{array}$ & $\begin{array}{c}-0.40^{* * *} \\
(0.04)\end{array}$ & $\begin{array}{c}-0.47^{* * *} \\
(0.04)\end{array}$ & $\begin{array}{c}-0.39^{* * *} \\
(0.04)\end{array}$ & $\begin{array}{c}-0.43^{* * *} \\
(0.04)\end{array}$ & $\begin{array}{c}-0.42^{* * *} \\
(0.04)\end{array}$ & $\begin{array}{c}-0.39^{* * *} \\
(0.03)\end{array}$ & $\begin{array}{c}-0.32^{* * *} \\
(0.03)\end{array}$ & $\begin{array}{c}-0.34^{* * *} \\
(0.03)\end{array}$ \\
\hline Sierra Centro & $\begin{array}{c}-0.32^{* * *} \\
(0.04)\end{array}$ & $\begin{array}{c}-0.37^{* * *} \\
(0.04)\end{array}$ & $\begin{array}{c}-0.42^{* * *} \\
(0.04)\end{array}$ & $\begin{array}{c}-0.42^{* * *} \\
(0.04)\end{array}$ & $\begin{array}{c}-0.46^{* * *} \\
(0.04)\end{array}$ & $\begin{array}{c}-0.30^{* * *} \\
(0.03)\end{array}$ & $\begin{array}{c}-0.39^{* * *} \\
(0.04)\end{array}$ & $\begin{array}{c}-0.36^{* * *} \\
(0.03)\end{array}$ & $\begin{array}{c}-0.35^{* * *} \\
(0.03)\end{array}$ & $\begin{array}{c}-0.35^{* * *} \\
(0.03)\end{array}$ & $\begin{array}{c}-0.33^{* * *} \\
(0.03)\end{array}$ & $\begin{array}{c}-0.31^{* * *} \\
(0.03)\end{array}$ & $\begin{array}{c}-0.28^{* * *} \\
(0.03)\end{array}$ & $\begin{array}{c}-0.24^{* * *} \\
(0.03)\end{array}$ & $\begin{array}{c}-0.26 * * * \\
(0.03)\end{array}$ \\
\hline Sierra Sur & $\begin{array}{c}-0.33^{* * *} \\
(0.04)\end{array}$ & $\begin{array}{c}-0.38^{* * *} \\
(0.04)\end{array}$ & $\begin{array}{c}-0.34^{* * *} \\
(0.04)\end{array}$ & $\begin{array}{c}-0.40^{* * *} \\
(0.04)\end{array}$ & $\begin{array}{c}-0.46^{* * *} \\
(0.04)\end{array}$ & $\begin{array}{c}-0.32^{* * *} \\
(0.04)\end{array}$ & $\begin{array}{c}-0.39^{* * *} \\
(0.04)\end{array}$ & $\begin{array}{c}-0.29^{* * *} \\
(0.03)\end{array}$ & $\begin{array}{c}-0.27^{* * *} \\
(0.03)\end{array}$ & $\begin{array}{c}-0.23^{* * *} \\
(0.03)\end{array}$ & $\begin{array}{c}-0.24^{* * *} \\
(0.03)\end{array}$ & $\begin{array}{c}-0.22^{* * *} \\
(0.03)\end{array}$ & $\begin{array}{c}-0.20^{* * *} \\
(0.03)\end{array}$ & $\begin{array}{c}-0.20^{* * *} \\
(0.03)\end{array}$ & $\begin{array}{c}-0.19^{* * *} \\
(0.03)\end{array}$ \\
\hline Selva & $\begin{array}{c}-0.22^{* * *} \\
(0.04)\end{array}$ & $\begin{array}{c}-0.22^{* * *} \\
(0.04)\end{array}$ & $\begin{array}{c}-0.18^{* * *} \\
(0.03)\end{array}$ & $\begin{array}{c}-0.16^{* * *} \\
(0.04)\end{array}$ & $\begin{array}{c}-0.25^{* * *} \\
(0.04)\end{array}$ & $\begin{array}{c}-0.21^{* * *} \\
(0.03)\end{array}$ & $\begin{array}{c}-0.26^{* * *} \\
(0.04)\end{array}$ & $\begin{array}{c}-0.13^{* * *} \\
(0.03)\end{array}$ & $\begin{array}{c}-0.16^{* * *} \\
(0.03)\end{array}$ & $\begin{array}{c}-0.18^{* * *} \\
(0.03)\end{array}$ & $\begin{array}{c}-0.21^{* * *} \\
(0.03)\end{array}$ & $\begin{array}{c}-0.17^{* * *} \\
(0.03)\end{array}$ & $\begin{array}{c}-0.18^{* * *} \\
(0.02)\end{array}$ & $\begin{array}{c}-0.15^{* * *} \\
(0.03)\end{array}$ & $\begin{array}{c}-0.15^{* * *} \\
(0.03)\end{array}$ \\
\hline Lima Metropolitana & $\begin{array}{c}0.17^{* * *} \\
(0.04)\end{array}$ & $\begin{array}{c}0.18^{* * *} \\
(0.04)\end{array}$ & $\begin{array}{c}0.15^{* * *} \\
(0.03)\end{array}$ & $\begin{array}{c}0.09^{* *} \\
(0.04)\end{array}$ & $\begin{array}{c}0.02 \\
(0.04)\end{array}$ & $\begin{array}{c}0.08^{* *} \\
(0.03)\end{array}$ & $\begin{array}{c}-0.07^{*} \\
(0.04)\end{array}$ & $\begin{array}{c}0.01 \\
(0.03)\end{array}$ & $\begin{array}{l}-0.00 \\
(0.03)\end{array}$ & $\begin{array}{l}-0.00 \\
(0.03)\end{array}$ & $\begin{array}{c}0.01 \\
(0.03)\end{array}$ & $\begin{array}{c}0.02 \\
(0.03)\end{array}$ & $\begin{array}{c}0.08^{* * *} \\
(0.02)\end{array}$ & $\begin{array}{c}0.10^{* * *} \\
(0.03)\end{array}$ & $\begin{array}{c}0.09^{* * *} \\
(0.02)\end{array}$ \\
\hline Index & $\begin{array}{c}0.00 \\
(.)\end{array}$ & $\begin{array}{c}1.09^{* * *} \\
(0.09)\end{array}$ & $\begin{array}{c}0.17^{* * *} \\
(0.01)\end{array}$ & $\begin{array}{c}0.10^{* * *} \\
(0.01)\end{array}$ & $\begin{array}{c}0.15^{* * *} \\
(0.01)\end{array}$ & $\begin{array}{c}0.14^{* * *} \\
(0.01)\end{array}$ & $\begin{array}{c}0.08^{* * *} \\
(0.01)\end{array}$ & $\begin{array}{c}0.05^{* * *} \\
(0.00)\end{array}$ & $\begin{array}{c}0.06^{* * *} \\
(0.00)\end{array}$ & $\begin{array}{c}0.09^{* * *} \\
(0.00)\end{array}$ & $\begin{array}{c}0.08^{* * *} \\
(0.01)\end{array}$ & $\begin{array}{c}0.14^{* * *} \\
(0.01)\end{array}$ & $\begin{array}{c}0.12^{* * *} \\
(0.01)\end{array}$ & $\begin{array}{c}0.08^{* * *} \\
(0.00)\end{array}$ & $\begin{array}{c}0.07^{* * *} \\
(0.00)\end{array}$ \\
\hline Constant & $\begin{array}{c}4.67^{* * *} \\
(0.07) \\
\end{array}$ & $\begin{array}{c}3.67^{* * *} \\
(0.12) \\
\end{array}$ & $\begin{array}{c}4.53^{* * *} \\
(0.07) \\
\end{array}$ & $\begin{array}{c}4.77^{* * *} \\
(0.07) \\
\end{array}$ & $\begin{array}{c}4.87^{* * *} \\
(0.08) \\
\end{array}$ & $\begin{array}{c}4.98^{* * *} \\
(0.08) \\
\end{array}$ & $\begin{array}{c}5.19^{* * *} \\
(0.08) \\
\end{array}$ & $\begin{array}{c}5.08^{* * *} \\
(0.08) \\
\end{array}$ & $\begin{array}{c}5.09^{* * *} \\
(0.08) \\
\end{array}$ & $\begin{array}{c}5.10^{* * *} \\
(0.07) \\
\end{array}$ & $\begin{array}{c}5.11^{* * *} \\
(0.07) \\
\end{array}$ & $\begin{array}{c}4.83^{* * *} \\
(0.08) \\
\end{array}$ & $\begin{array}{c}4.99^{* * *} \\
(0.08)\end{array}$ & $\begin{array}{c}5.04^{* * *} \\
(0.06) \\
\end{array}$ & $\begin{array}{c}4.94^{* * *} \\
(0.07) \\
\end{array}$ \\
\hline Observations & 19,370 & 19,074 & 20,351 & 21,912 & 21,219 & 21,557 & 21,193 & 24,146 & 24,009 & 28,377 & 28,101 & 28,376 & 31,183 & 29,699 & 31,479 \\
\hline R-squared & 0.42 & 0.42 & 0.43 & 0.41 & 0.37 & 0.34 & 0.32 & 0.32 & 0.34 & 0.33 & 0.37 & 0.36 & 0.36 & 0.37 & 0.35 \\
\hline
\end{tabular}

Note: standard errors in parentheses. ${ }^{*} p<0.1,{ }^{* *} p<0.05,{ }^{* * *} p<0.01$.

Source: authors' compilation based on data from ENAHO. 
Table A9: Log earnings OLS: female population with controls and ISCO-88 two-digit fixed effects

\begin{tabular}{|c|c|c|c|c|c|c|c|c|c|c|c|c|c|c|c|}
\hline & 2004 & 2005 & 2006 & 2007 & 2008 & 2009 & 2010 & 2011 & 2012 & 2013 & 2014 & 2015 & 2016 & 2017 & 2018 \\
\hline \multicolumn{16}{|c|}{ Education level (base: no schooling) } \\
\hline Primary & $\begin{array}{c}0.26^{* * *} \\
(0.05)\end{array}$ & $\begin{array}{c}0.39^{* * *} \\
(0.05)\end{array}$ & $\begin{array}{c}0.33^{* * *} \\
(0.05)\end{array}$ & $\begin{array}{c}0.21^{* * *} \\
(0.05)\end{array}$ & $\begin{array}{c}0.30^{* * *} \\
(0.05)\end{array}$ & $\begin{array}{c}0.37^{* * *} \\
(0.05)\end{array}$ & $\begin{array}{c}0.22^{* * *} \\
(0.05)\end{array}$ & $\begin{array}{c}0.29^{* * *} \\
(0.05)\end{array}$ & $\begin{array}{c}0.40^{* * *} \\
(0.06)\end{array}$ & $\begin{array}{c}0.28^{* * *} \\
(0.05)\end{array}$ & $\begin{array}{c}0.33^{* * *} \\
(0.05)\end{array}$ & $\begin{array}{c}0.20^{* * *} \\
(0.05)\end{array}$ & $\begin{array}{c}0.19^{* * *} \\
(0.05)\end{array}$ & $\begin{array}{c}0.26^{* * *} \\
(0.04)\end{array}$ & $\begin{array}{c}0.18^{* * *} \\
(0.05)\end{array}$ \\
\hline Secondary & $\begin{array}{c}0.47^{* * *} \\
(0.05)\end{array}$ & $\begin{array}{c}0.64^{* * *} \\
(0.05)\end{array}$ & $\begin{array}{c}0.52^{* * *} \\
(0.05)\end{array}$ & $\begin{array}{c}0.48^{* * *} \\
(0.05)\end{array}$ & $\begin{array}{c}0.52^{* * *} \\
(0.05)\end{array}$ & $\begin{array}{c}0.58^{* * *} \\
(0.05)\end{array}$ & $\begin{array}{c}0.43^{* * *} \\
(0.05)\end{array}$ & $\begin{array}{c}0.49^{* * *} \\
(0.05)\end{array}$ & $\begin{array}{c}0.60^{* * *} \\
(0.06)\end{array}$ & $\begin{array}{c}0.51^{* * *} \\
(0.06)\end{array}$ & $\begin{array}{c}0.53^{* * *} \\
(0.05)\end{array}$ & $\begin{array}{c}0.43^{* * *} \\
(0.05)\end{array}$ & $\begin{array}{c}0.41^{* * *} \\
(0.05)\end{array}$ & $\begin{array}{c}0.49^{* * *} \\
(0.04)\end{array}$ & $\begin{array}{c}0.49^{* * *} \\
(0.05)\end{array}$ \\
\hline Tertiary & $\begin{array}{c}0.57^{* * *} \\
(0.06)\end{array}$ & $\begin{array}{c}0.76^{* * *} \\
(0.06)\end{array}$ & $\begin{array}{c}0.67^{* * *} \\
(0.06)\end{array}$ & $\begin{array}{c}0.62^{* * *} \\
(0.06)\end{array}$ & $\begin{array}{c}0.69^{* * *} \\
(0.06)\end{array}$ & $\begin{array}{c}0.72^{* * *} \\
(0.06)\end{array}$ & $\begin{array}{c}0.56^{* * *} \\
(0.06)\end{array}$ & $\begin{array}{c}0.57^{* * *} \\
(0.05)\end{array}$ & $\begin{array}{c}0.74^{* * *} \\
(0.06)\end{array}$ & $\begin{array}{c}0.67^{* * *} \\
(0.06)\end{array}$ & $\begin{array}{c}0.66^{* * *} \\
(0.06)\end{array}$ & $\begin{array}{c}0.56^{* * *} \\
(0.05)\end{array}$ & $\begin{array}{c}0.56^{* * *} \\
(0.05)\end{array}$ & $\begin{array}{c}0.62^{* * *} \\
(0.05)\end{array}$ & $\begin{array}{c}0.67^{* * *} \\
(0.05)\end{array}$ \\
\hline \multicolumn{16}{|c|}{ Age group (base: $25-44$ ) } \\
\hline $15-24$ & $\begin{array}{c}-0.33^{* * *} \\
(0.03)\end{array}$ & $\begin{array}{c}-0.30^{* * *} \\
(0.03)\end{array}$ & $\begin{array}{c}-0.27^{* * *} \\
(0.03)\end{array}$ & $\begin{array}{c}-0.33^{* * *} \\
(0.03)\end{array}$ & $\begin{array}{c}-0.34^{* * *} \\
(0.03)\end{array}$ & $\begin{array}{c}-0.34^{* * *} \\
(0.03)\end{array}$ & $\begin{array}{c}-0.38^{* * *} \\
(0.03)\end{array}$ & $\begin{array}{c}-0.36^{* * *} \\
(0.03)\end{array}$ & $\begin{array}{c}-0.31^{* * *} \\
(0.03)\end{array}$ & $\begin{array}{c}-0.35^{* * *} \\
(0.03)\end{array}$ & $\begin{array}{c}-0.32^{* * * *} \\
(0.02)\end{array}$ & $\begin{array}{c}-0.34^{* * *} \\
(0.03)\end{array}$ & $\begin{array}{c}-0.32^{* * *} \\
(0.02)\end{array}$ & $\begin{array}{c}-0.35^{* * *} \\
(0.03)\end{array}$ & $\begin{array}{c}-0.38^{* * *} \\
(0.03)\end{array}$ \\
\hline $45-64$ & $\begin{array}{c}0.02 \\
(0.03)\end{array}$ & $\begin{array}{c}0.10^{* * *} \\
(0.03)\end{array}$ & $\begin{array}{l}0.05^{*} \\
(0.03)\end{array}$ & $\begin{array}{c}0.08^{* * *} \\
(0.03)\end{array}$ & $\begin{array}{c}0.07^{* * *} \\
(0.03)\end{array}$ & $\begin{array}{c}0.09^{* * *} \\
(0.03)\end{array}$ & $\begin{array}{l}0.04^{*} \\
(0.03)\end{array}$ & $\begin{array}{c}0.07^{* * *} \\
(0.02)\end{array}$ & $\begin{array}{c}0.09^{* * *} \\
(0.02)\end{array}$ & $\begin{array}{c}0.08^{* * *} \\
(0.02)\end{array}$ & $\begin{array}{c}0.06^{* * *} \\
(0.02)\end{array}$ & $\begin{array}{c}0.07^{* * *} \\
(0.02)\end{array}$ & $\begin{array}{c}0.05^{* * *} \\
(0.02)\end{array}$ & $\begin{array}{c}0.07^{* * *} \\
(0.02)\end{array}$ & $\begin{array}{c}0.08^{* * *} \\
(0.02)\end{array}$ \\
\hline \multicolumn{16}{|c|}{ Dominio (base: Costa Sur) } \\
\hline Costa Norte & $\begin{array}{c}-0.23^{* * *} \\
(0.05)\end{array}$ & $\begin{array}{c}-0.36^{* * *} \\
(0.05)\end{array}$ & $\begin{array}{c}-0.29 * * * \\
(0.05)\end{array}$ & $\begin{array}{c}-0.42^{* * *} \\
(0.05)\end{array}$ & $\begin{array}{c}-0.47^{* * *} \\
(0.06)\end{array}$ & $\begin{array}{c}-0.36^{* * *} \\
(0.04)\end{array}$ & $\begin{array}{c}-0.43^{* * *} \\
(0.05)\end{array}$ & $\begin{array}{c}-0.32^{* * *} \\
(0.04)\end{array}$ & $\begin{array}{c}-0.39 * * * \\
(0.04)\end{array}$ & $\begin{array}{c}-0.45^{* * *} \\
(0.04)\end{array}$ & $\begin{array}{c}-0.44^{* * *} \\
(0.04)\end{array}$ & $\begin{array}{c}-0.37^{* * *} \\
(0.04)\end{array}$ & $\begin{array}{c}-0.35^{* * *} \\
(0.03)\end{array}$ & $\begin{array}{c}-0.36^{* * *} \\
(0.03)\end{array}$ & $\begin{array}{c}-0.32^{* * *} \\
(0.03)\end{array}$ \\
\hline Costa Centro & $\begin{array}{l}-0.02 \\
(0.05)\end{array}$ & $\begin{array}{c}0.02 \\
(0.06)\end{array}$ & $\begin{array}{l}-0.04 \\
(0.06)\end{array}$ & $\begin{array}{l}-0.06 \\
(0.05)\end{array}$ & $\begin{array}{l}-0.09 \\
(0.06)\end{array}$ & $\begin{array}{c}-0.15^{* * *} \\
(0.05)\end{array}$ & $\begin{array}{c}-0.09^{*} \\
(0.05)\end{array}$ & $\begin{array}{c}-0.14^{* * *} \\
(0.05)\end{array}$ & $\begin{array}{c}-0.15^{* * *} \\
(0.04)\end{array}$ & $\begin{array}{c}-0.23^{* * *} \\
(0.04)\end{array}$ & $\begin{array}{c}-0.17^{* * *} \\
(0.04)\end{array}$ & $\begin{array}{c}-0.11^{* *} \\
(0.04)\end{array}$ & $\begin{array}{l}-0.02 \\
(0.03)\end{array}$ & $\begin{array}{c}-0.14^{* * *} \\
(0.03)\end{array}$ & $\begin{array}{l}-0.05 \\
(0.03)\end{array}$ \\
\hline Sierra Norte & $\begin{array}{c}-0.43^{* * *} \\
(0.07)\end{array}$ & $\begin{array}{c}-0.49^{* * *} \\
(0.07)\end{array}$ & $\begin{array}{c}-0.46^{* * *} \\
(0.07)\end{array}$ & $\begin{array}{c}-0.67^{* * *} \\
(0.06)\end{array}$ & $\begin{array}{c}-0.72^{* * *} \\
(0.07)\end{array}$ & $\begin{array}{c}-0.75^{* * *} \\
(0.06)\end{array}$ & $\begin{array}{c}-0.72^{* * *} \\
(0.06)\end{array}$ & $\begin{array}{c}-0.51^{* * *} \\
(0.06)\end{array}$ & $\begin{array}{c}-0.60^{* * *} \\
(0.06)\end{array}$ & $\begin{array}{c}-0.75^{* * *} \\
(0.06)\end{array}$ & $\begin{array}{c}-0.62^{* * *} \\
(0.05)\end{array}$ & $\begin{array}{c}-0.71^{* * * *} \\
(0.06)\end{array}$ & $\begin{array}{c}-0.66^{* * *} \\
(0.04)\end{array}$ & $\begin{array}{c}-0.72^{* * *} \\
(0.05)\end{array}$ & $\begin{array}{c}-0.66^{* * *} \\
(0.04)\end{array}$ \\
\hline Sierra Centro & $\begin{array}{c}-0.31^{* * *} \\
(0.05)\end{array}$ & $\begin{array}{c}-0.31^{* * *} \\
(0.05)\end{array}$ & $\begin{array}{c}-0.31^{* * *} \\
(0.05)\end{array}$ & $\begin{array}{c}-0.41^{* * *} \\
(0.05)\end{array}$ & $\begin{array}{c}-0.37^{* * *} \\
(0.05)\end{array}$ & $\begin{array}{c}-0.38^{* * *} \\
(0.04)\end{array}$ & $\begin{array}{c}-0.39^{* * *} \\
(0.04)\end{array}$ & $\begin{array}{c}-0.38^{* * *} \\
(0.04)\end{array}$ & $\begin{array}{c}-0.39 * * * \\
(0.04)\end{array}$ & $\begin{array}{c}-0.43^{* * *} \\
(0.04)\end{array}$ & $\begin{array}{c}-0.41^{* * *} \\
(0.04)\end{array}$ & $\begin{array}{c}-0.38^{* * *} \\
(0.04)\end{array}$ & $\begin{array}{c}-0.34^{* * *} \\
(0.03)\end{array}$ & $\begin{array}{c}-0.42^{* * *} \\
(0.03)\end{array}$ & $\begin{array}{c}-0.42^{* * *} \\
(0.03)\end{array}$ \\
\hline Sierra Sur & $\begin{array}{c}-0.26^{* * *} \\
(0.05)\end{array}$ & $\begin{array}{c}-0.34^{* * *} \\
(0.05)\end{array}$ & $\begin{array}{c}-0.31^{* * *} \\
(0.05)\end{array}$ & $\begin{array}{c}-0.31^{* * *} \\
(0.05)\end{array}$ & $\begin{array}{c}-0.35^{* * *} \\
(0.05)\end{array}$ & $\begin{array}{c}-0.29^{* * *} \\
(0.04)\end{array}$ & $\begin{array}{c}-0.28^{* * *} \\
(0.04)\end{array}$ & $\begin{array}{c}-0.21^{* * *} \\
(0.04)\end{array}$ & $\begin{array}{c}-0.21^{* * *} \\
(0.04)\end{array}$ & $\begin{array}{c}-0.25^{* * *} \\
(0.04)\end{array}$ & $\begin{array}{c}-0.14^{* * *} \\
(0.04)\end{array}$ & $\begin{array}{c}-0.19^{* * *} \\
(0.04)\end{array}$ & $\begin{array}{c}-0.11^{* * *} \\
(0.03)\end{array}$ & $\begin{array}{c}-0.21^{* * *} \\
(0.03)\end{array}$ & $\begin{array}{c}-0.24^{* * *} \\
(0.03)\end{array}$ \\
\hline Selva & $\begin{array}{c}-0.12^{* *} \\
(0.05)\end{array}$ & $\begin{array}{c}-0.21^{* * *} \\
(0.05)\end{array}$ & $\begin{array}{c}-0.18^{* * *} \\
(0.05)\end{array}$ & $\begin{array}{c}-0.19^{* * *} \\
(0.05)\end{array}$ & $\begin{array}{c}-0.19^{* * *} \\
(0.05)\end{array}$ & $\begin{array}{c}-0.23^{* * *} \\
(0.04)\end{array}$ & $\begin{array}{c}-0.32^{* * *} \\
(0.04)\end{array}$ & $\begin{array}{c}-0.21^{* * *} \\
(0.04)\end{array}$ & $\begin{array}{c}-0.22^{* * *} \\
(0.04)\end{array}$ & $\begin{array}{c}-0.30^{* * *} \\
(0.04)\end{array}$ & $\begin{array}{c}-0.29^{* * *} \\
(0.04)\end{array}$ & $\begin{array}{c}-0.27^{* * *} \\
(0.04)\end{array}$ & $\begin{array}{c}-0.25^{* * *} \\
(0.03)\end{array}$ & $\begin{array}{c}-0.27^{* * *} \\
(0.03)\end{array}$ & $\begin{array}{c}-0.26^{* * *} \\
(0.03)\end{array}$ \\
\hline Lima Metropolitana & $\begin{array}{c}0.41^{* * *} \\
(0.05)\end{array}$ & $\begin{array}{c}0.32^{* * *} \\
(0.05)\end{array}$ & $\begin{array}{c}0.30^{* * *} \\
(0.05)\end{array}$ & $\begin{array}{l}0.11^{* *} \\
(0.05)\end{array}$ & $\begin{array}{c}0.17^{* * *} \\
(0.05)\end{array}$ & $\begin{array}{l}0.07^{*} \\
(0.04)\end{array}$ & $\begin{array}{c}0.06 \\
(0.04)\end{array}$ & $\begin{array}{c}0.13^{* * *} \\
(0.04)\end{array}$ & $\begin{array}{c}0.10^{* * * *} \\
(0.04)\end{array}$ & $\begin{array}{c}0.10^{* * *} \\
(0.04)\end{array}$ & $\begin{array}{c}0.11^{* * *} \\
(0.04)\end{array}$ & $\begin{array}{c}0.18^{* * *} \\
(0.04)\end{array}$ & $\begin{array}{c}0.21 * * * \\
(0.03)\end{array}$ & $\begin{array}{c}0.12^{* * *} \\
(0.03)\end{array}$ & $\begin{array}{c}0.08^{* * *} \\
(0.03)\end{array}$ \\
\hline Index & $\begin{array}{c}0.00 \\
(.)\end{array}$ & $\begin{array}{c}1.85^{* * *} \\
(0.23)\end{array}$ & $\begin{array}{l}0.11^{*} \\
(0.06)\end{array}$ & $\begin{array}{c}0.22^{* * *} \\
(0.03)\end{array}$ & $\begin{array}{c}0.27^{* * *} \\
(0.04)\end{array}$ & $\begin{array}{c}0.47^{* * *} \\
(0.05)\end{array}$ & $\begin{array}{c}0.11^{* * *} \\
(0.02)\end{array}$ & $\begin{array}{c}0.08^{* * *} \\
(0.01)\end{array}$ & $\begin{array}{c}0.11^{* * *} \\
(0.02)\end{array}$ & $\begin{array}{c}0.16^{* * *} \\
(0.02)\end{array}$ & $\begin{array}{c}0.18^{* * *} \\
(0.02)\end{array}$ & $\begin{array}{c}0.27^{* * *} \\
(0.03)\end{array}$ & $\begin{array}{c}0.19^{* * *} \\
(0.03)\end{array}$ & $\begin{array}{c}0.13^{* * *} \\
(0.02)\end{array}$ & $\begin{array}{c}0.14^{* * *} \\
(0.01)\end{array}$ \\
\hline Constant & $\begin{array}{c}4.05^{* * *} \\
(0.07) \\
\end{array}$ & $\begin{array}{c}2.15^{* * *} \\
(0.24) \\
\end{array}$ & $\begin{array}{c}3.99^{* * *} \\
(0.09) \\
\end{array}$ & $\begin{array}{c}4.12^{* * *} \\
(0.07) \\
\end{array}$ & $\begin{array}{c}3.97^{* * *} \\
(0.08) \\
\end{array}$ & $\begin{array}{c}3.79^{* * *} \\
(0.08) \\
\end{array}$ & $\begin{array}{c}4.36^{* * *} \\
(0.07) \\
\end{array}$ & $\begin{array}{c}4.35^{* * *} \\
(0.06) \\
\end{array}$ & $\begin{array}{c}4.22^{* * *} \\
(0.07) \\
\end{array}$ & $\begin{array}{c}4.34^{* * *} \\
(0.07) \\
\end{array}$ & $\begin{array}{c}4.26^{* * *} \\
(0.07) \\
\end{array}$ & $\begin{array}{c}4.28^{* * *} \\
(0.07) \\
\end{array}$ & $\begin{array}{c}4.33^{* * *} \\
(0.06) \\
\end{array}$ & $\begin{array}{c}4.42^{* * *} \\
(0.06) \\
\end{array}$ & $\begin{array}{c}4.40^{* * *} \\
(0.06) \\
\end{array}$ \\
\hline Observations & 12,815 & 12,528 & 13,642 & 15,886 & 15,530 & 15,875 & 16,151 & 18,373 & 18,491 & 22,071 & 22,142 & 21,557 & 24,820 & 23,684 & 25,435 \\
\hline R-squared & 0.37 & 0.38 & 0.38 & 0.38 & 0.35 & 0.35 & 0.32 & 0.31 & 0.33 & 0.35 & 0.36 & 0.36 & 0.38 & 0.37 & 0.34 \\
\hline
\end{tabular}

Note: standard errors in parentheses. ${ }^{*} p<0.1,{ }^{* *} p<0.05,{ }^{* * *} p<0.01$.

Source: authors' compilation based on data from ENAHO. 


\section{A3 Relationship between occupational earnings and employment}

Table A10: Relationship between occupational earnings and employment

\begin{tabular}{lccc}
\hline & $(1)$ & $(2)$ & $(3)$ \\
& \multicolumn{3}{c}{ Change in log(empl. share) } \\
\cline { 2 - 4 } Variables & $2004-11$ & $2011-18$ & $2004-18$ \\
\hline Change in log(earnings) & -0.268 & 0.120 & -5.046 \\
& $(0.460)$ & $(0.134)$ & $(30.582)$ \\
Observations & & & 25 \\
R-squared & 25 & 25 & 0.002 \\
Adj. R-squared & 0.024 & 0.042 & -0.0399 \\
F-test & -0.0171 & 0.00228 & 0.870 \\
\hline Note: standard errors in parentheses. ${ }^{*} p<0.1,{ }^{* *} p<0.05, * * *$ & 0.378 &
\end{tabular}

Note: standard errors in parentheses. ${ }^{*} p<0.1,{ }^{* *} p<0.05,{ }^{* * *} p<0.01$.

Source: authors' compilation based on data from ENAHO.

A4 Average years of education and labour earnings by occupation (ISCO-88)

Figure A1: Average years of education distribution (2014-8) by occupation (ISCO-88)

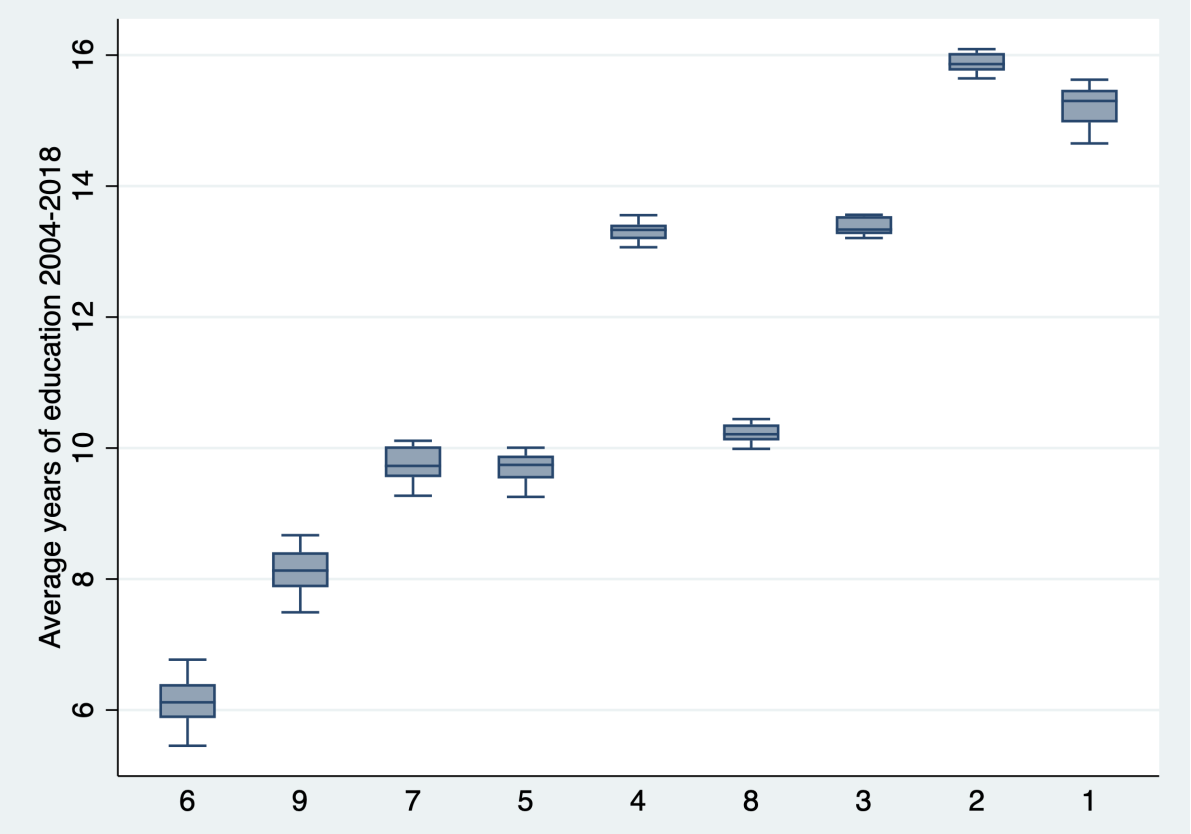

Note: ISCO-88 one-digit codification in the horizontal axis, sorted by their real earnings historical mean.

Source: authors' compilation based on data from ENAHO. 


\section{A5 Employment and earnings polarization effects}

Table A11: Employment polarization regressions at alternative time lags

\begin{tabular}{|c|c|c|c|c|c|c|}
\hline \multirow[b]{2}{*}{ Variables } & \multicolumn{3}{|c|}{ log(empl. share) } & \multicolumn{3}{|c|}{ log(earnings) } \\
\hline & 2004-11 & $2011-18$ & 2004-18 & 2004-11 & $2011-18$ & 2004-18 \\
\hline Log(earnings) $t-1$ & $\begin{array}{c}84.459^{\star \star \star} \\
(23.163)\end{array}$ & $\begin{array}{c}-18.049^{*} \\
(10.119)\end{array}$ & $\begin{array}{c}-4,402.705^{\star} \\
(2,223.027)\end{array}$ & $\begin{array}{c}-25.490^{\star \star \star} \\
(6.658)\end{array}$ & $\begin{array}{c}23.116 \\
(14.948)\end{array}$ & $\begin{array}{c}207.070 \\
(1,416.092)\end{array}$ \\
\hline Log(earnings) $t-1$ squared & $\begin{array}{c}-8.220^{\star \star \star} \\
(2.216)\end{array}$ & $\begin{array}{l}1.801^{*} \\
(0.947)\end{array}$ & $\begin{array}{l}410.478^{*} \\
(208.766)\end{array}$ & $\begin{array}{c}2.782^{\star * \star} \\
(0.619)\end{array}$ & $\begin{array}{l}-2.280 \\
(1.343)\end{array}$ & $\begin{array}{c}-38.364 \\
(122.813)\end{array}$ \\
\hline Constant & $\begin{array}{c}-213.084^{\star \star \star} \\
(59.729)\end{array}$ & $\begin{array}{c}44.659 \\
(26.740)\end{array}$ & $\begin{array}{c}11,528.772^{*} \\
(5,829.999)\end{array}$ & $\begin{array}{c}57.887^{\star \star \star} \\
(17.533)\end{array}$ & $\begin{array}{l}-58.353 \\
(40.848)\end{array}$ & $\begin{array}{c}-252.106 \\
(3,899.919)\end{array}$ \\
\hline Observations & 25 & 25 & 25 & 25 & 25 & 25 \\
\hline R-squared & 0.632 & 0.261 & 0.224 & 0.686 & 0.146 & 0.062 \\
\hline Adj. R-squared & 0.598 & 0.194 & 0.154 & 0.657 & 0.0682 & -0.0235 \\
\hline F-test & 0.00417 & 0.0987 & 0.164 & $1.25 \mathrm{e}-06$ & 0.108 & 0.173 \\
\hline
\end{tabular}

Note: standard errors in parentheses. ${ }^{*} p<0.1,{ }^{* *} p<0.05,{ }^{* * *} p<0.01$.

Source: authors' compilation based on data from ENAHO.

Table A12: Change in earnings and employment (O*NET RTI)

\begin{tabular}{lcccccccc}
\hline & \multicolumn{3}{c}{ Change in empl. share } & & \multicolumn{3}{c}{ Change in log earnings } \\
\cline { 2 - 3 } \cline { 8 - 9 } & $2004-11$ & $2011-18$ & $2004-18$ & & $2004-11$ & $2011-18$ & $2004-18$ \\
\hline Baseline RTI (O*NET) & -0.686 & $-0.722^{* *}$ & 58.484 & & -0.766 & 0.436 & 87.350 \\
& $(0.507)$ & $(0.319)$ & $(39.039)$ & & $(0.629)$ & $(0.256)$ & $(58.788)$ \\
Baseline RTI (O*NET) squared & 0.211 & 0.328 & 42.827 & & 0.430 & -0.107 & -13.306 \\
& $(0.261)$ & $(0.222)$ & $(31.448)$ & & $(0.406)$ & $(0.176)$ & $(40.357)$ \\
Constant & 0.096 & -0.068 & -76.433 & & -0.264 & -0.374 & -19.160 \\
& $(0.675)$ & $(0.595)$ & $(54.697)$ & & $(0.601)$ & $(0.375)$ & $(65.375)$ \\
\hline Observations & 25 & 25 & 25 & & 25 & 25 & 25 \\
R-squared & 0.053 & 0.130 & 0.111 & & 0.127 & 0.074 & 0.077 \\
\hline
\end{tabular}

Note: clustered standard errors in parentheses. Clustered by ISCO-88 two-digit level. ${ }^{*} p<0.1,{ }^{* *} p<0.05,{ }^{* * *} p<0.01$.

Source: authors' compilation based on data from ENAHO. 
Table A13: RIF inequality decomposition, 2004-11 (real earnings)

\begin{tabular}{|c|c|c|c|c|c|c|c|c|c|c|}
\hline & $q 10$ & q20 & q30 & $q 40$ & q50 & $q 60$ & q70 & q80 & q90 & Gini \\
\hline \multicolumn{11}{|l|}{ Distribution } \\
\hline Final $\mathrm{F}$ & $34.242^{* * *}$ & $70.450^{* * *}$ & $107.033^{* * *}$ & $142.078^{* * *}$ & $176.432^{* * *}$ & $213.197^{* * *}$ & $267.664^{* * *}$ & $341.252^{* * *}$ & $491.444^{* * *}$ & $0.504^{* * *}$ \\
\hline Initial I & $25.222^{* * *}$ & $48.213^{* * *}$ & $72.300^{* * *}$ & $98.323^{* * *}$ & $126.654^{* * *}$ & $158.423^{* * *}$ & $200.209^{* * *}$ & $260.880^{* * *}$ & $364.193^{* * *}$ & $0.533^{* * *}$ \\
\hline Total Change F-I & $9.019^{* * *}$ & $22.237^{* * *}$ & $34.733^{* * *}$ & $43.755^{* * *}$ & $49.779^{* * *}$ & $54.773^{* * *}$ & $67.454^{* * *}$ & $80.372^{* * *}$ & $127.250^{* * *}$ & $-0.029^{* * *}$ \\
\hline \multicolumn{11}{|l|}{ Reweighting Decomposition } \\
\hline Counterfactual C & $26.949^{* * *}$ & $51.074^{* * *}$ & $77.254^{* * *}$ & $105.952^{* * *}$ & $138.039^{* * *}$ & $172.187^{* * *}$ & $220.839^{* * *}$ & $282.258^{* * *}$ & $404.657^{* * *}$ & $0.541^{* * *}$ \\
\hline Total composition C-I & $1.727^{* * *}$ & $2.860^{* * *}$ & $4.954^{* * *}$ & $7.628^{* * *}$ & $11.385^{* * *}$ & $13.764^{* * *}$ & $20.630^{* * *}$ & $21.378^{* * *}$ & $40.464^{* * *}$ & $0.008^{* * *}$ \\
\hline Total earnings structure F-C & $7.293^{* * *}$ & $19.376^{* * *}$ & $29.779^{* * *}$ & $36.127^{* * *}$ & $38.394^{* * *}$ & $41.010^{* * *}$ & $46.825^{* * *}$ & $58.994^{* * *}$ & $86.787^{* * *}$ & $-0.037^{* * *}$ \\
\hline \multicolumn{11}{|l|}{ RIF aggregate decomposition } \\
\hline RIF composition & $2.047^{* * *}$ & $3.963^{* * *}$ & $6.133^{* * *}$ & $8.931^{* * *}$ & $11.766^{* * *}$ & $14.109^{* * *}$ & $20.170^{* * *}$ & $25.280^{* * *}$ & $34.128^{* * *}$ & $0.010^{* * *}$ \\
\hline RIF specification error & -0.321 & $-1.103^{* * *}$ & $-1.179^{* * *}$ & $-1.302^{* *}$ & -0.381 & -0.345 & 0.460 & $-3.901^{* * *}$ & $6.336^{*}$ & -0.002 \\
\hline RIF earnings structure & $7.416^{* * *}$ & $19.611^{* * *}$ & $30.135^{* * *}$ & $36.643^{* * *}$ & $39.110^{* * *}$ & $41.984^{* * *}$ & $48.201^{* * *}$ & $60.290^{* * *}$ & $89.339^{* * *}$ & $-0.037^{* * *}$ \\
\hline RIF reweighting error & $-0.124^{* * *}$ & $-0.235^{* * *}$ & $-0.356^{* * *}$ & $-0.516^{* * *}$ & $-0.716^{* * *}$ & $-0.975^{* * *}$ & $-1.376^{* * *}$ & $-1.296^{* * *}$ & $-2.553^{* * *}$ & $-0.000^{* *}$ \\
\hline \multicolumn{11}{|l|}{ RIF composition } \\
\hline Gender & $-0.525^{* * *}$ & $-0.760^{* * *}$ & $-0.922^{* * *}$ & $-1.031^{* * *}$ & $-1.105^{* * *}$ & $-1.224^{* * *}$ & $-1.298^{* * *}$ & $-1.314^{* * *}$ & $-2.886^{* * *}$ & -0.000 \\
\hline Education level & $1.429^{* * *}$ & $2.504^{* * *}$ & $3.909^{* * *}$ & $5.106^{* * *}$ & $5.753^{* * *}$ & $6.299^{* * *}$ & $8.071^{* * *}$ & $9.404^{* * *}$ & $14.125^{* * *}$ & -0.000 \\
\hline Age & $0.218^{* * *}$ & $0.307^{* * *}$ & $0.431^{* * *}$ & $0.726^{* * *}$ & $1.064^{* * *}$ & $1.372^{* * *}$ & $2.081^{* * *}$ & $2.646^{* * *}$ & $4.456^{* * *}$ & $0.002^{* * *}$ \\
\hline Routine task intensity & $0.925^{* * *}$ & $1.912^{* * *}$ & $2.716^{* * *}$ & $4.130^{* * *}$ & $6.053^{* * *}$ & $7.662^{* * *}$ & $11.316^{* * *}$ & $14.543^{* * *}$ & $18.433^{* * *}$ & $0.008^{* * *}$ \\
\hline Explained & $2.047^{* * *}$ & $3.963^{* * *}$ & $6.133^{* * *}$ & $8.931^{* * *}$ & $11.766^{* * *}$ & $14.109^{* * *}$ & $20.170^{* * *}$ & $25.280^{* * *}$ & $34.128^{* * *}$ & $0.010^{* * *}$ \\
\hline \multicolumn{11}{|l|}{ RIF earnings structure } \\
\hline Gender & $9.887^{* * *}$ & $16.553^{* * *}$ & $18.272^{* * *}$ & $14.945^{* * *}$ & $16.364^{* * *}$ & $19.192^{* * *}$ & $27.343^{* * *}$ & $33.785^{* * *}$ & -9.249 & $-0.032^{* * *}$ \\
\hline Education level & -8.433 & 9.861 & 8.475 & -6.895 & -9.568 & -4.988 & 8.816 & $23.962^{* *}$ & -19.595 & 0.027 \\
\hline Age & $23.854^{* * *}$ & $28.570^{* *}$ & $34.803^{* * *}$ & $32.882^{* *}$ & -1.987 & 6.133 & $50.568^{* *}$ & $91.114^{* * *}$ & 64.675 & $0.126^{*}$ \\
\hline Routine task intensity & $-7.159^{* * *}$ & $-11.090^{* * *}$ & $-10.185^{* * *}$ & $-3.327^{* *}$ & -0.610 & 0.269 & 2.498 & -6.847 & 11.658 & 0.014 \\
\hline Constant & -10.733 & -24.283 & -21.230 & -0.961 & $34.910^{* *}$ & 21.378 & -41.024 & $-81.724^{* *}$ & 41.851 & $-0.172^{* *}$ \\
\hline Unexplained & $7.416^{* * *}$ & $19.611^{* * *}$ & $30.135^{* * *}$ & $36.643^{* * *}$ & $39.110^{* * *}$ & $41.984^{* * *}$ & $48.201^{* * *}$ & $60.290^{* * *}$ & $89.339^{* * *}$ & $-0.037^{* * *}$ \\
\hline Observations & 89,540 & 89,540 & 89,540 & 89,540 & 89,540 & 89,540 & 89,540 & 89,540 & 89,540 & 89,540 \\
\hline
\end{tabular}

Note: ${ }^{*} p<0.1,{ }^{* *} p<0.05,{ }^{* * *} p<0.01$.

Source: authors' compilation based on data from ENAHO. 
Table A14: RIF inequality decomposition, 2011-18 (real earnings)

\begin{tabular}{|c|c|c|c|c|c|c|c|c|c|c|}
\hline & $q 10$ & $\mathrm{q} 20$ & q30 & $\mathrm{q} 40$ & q50 & $\mathrm{q} 60$ & q70 & q80 & q90 & Gini \\
\hline \multicolumn{11}{|l|}{ Distribution } \\
\hline Final F & $41.997^{* * *}$ & $82.506^{* * *}$ & $125.412^{* * *}$ & $166.027^{* * *}$ & $201.770^{* * *}$ & $244.302^{* * *}$ & $297.904^{* * *}$ & $385.130^{* * *}$ & $539.766^{* * *}$ & $0.469^{* * *}$ \\
\hline Initial I & $34.242^{* * *}$ & $70.450^{* * *}$ & $107.033^{* * *}$ & $142.078^{* * *}$ & $176.432^{* * *}$ & $213.197^{* * *}$ & $267.664^{* * *}$ & $341.252^{* * *}$ & $491.444^{* * *}$ & $0.504^{* * *}$ \\
\hline Total change F-I & $7.755^{* * *}$ & $12.056^{* * *}$ & $18.379^{* * *}$ & $23.949^{* * *}$ & $25.337^{* * *}$ & $31.106^{* * *}$ & $30.241^{* * *}$ & $43.878^{* * *}$ & $48.322^{* * *}$ & $-0.035^{* * *}$ \\
\hline \multicolumn{11}{|l|}{ Reweighting decomposition } \\
\hline Counterfactual C & $35.066^{* * *}$ & $71.716^{* * *}$ & $110.034^{* * *}$ & $145.013^{* * *}$ & $181.170^{* * *}$ & $220.217^{* * *}$ & $277.471^{* * *}$ & $349.631^{* * *}$ & $508.322^{* * *}$ & $0.505^{* * *}$ \\
\hline Total composition C-I & $0.824^{* *}$ & $1.266^{* * *}$ & $3.001^{* * *}$ & $2.935^{* * *}$ & $4.737^{* * *}$ & $7.021^{* * *}$ & $9.807^{* * *}$ & $8.379^{* * *}$ & $16.878^{* * *}$ & $0.002^{* *}$ \\
\hline Total earnings structure $\mathrm{F}-\mathrm{C}$ & $6.931^{* * *}$ & $10.790^{* * *}$ & $15.378^{* * *}$ & $21.014^{* * *}$ & $20.600^{* * *}$ & $24.085^{* * *}$ & $20.433^{* * *}$ & $35.499^{* * *}$ & $31.443^{* * *}$ & $-0.037^{* * *}$ \\
\hline \multicolumn{11}{|l|}{ RIF aggregate decomposition } \\
\hline RIF composition & $1.534^{* * *}$ & $2.750^{* * *}$ & $3.942^{* * *}$ & $4.496^{* * *}$ & $5.093^{* * *}$ & $6.489^{* * *}$ & $8.899^{* * *}$ & $9.466^{* * *}$ & $15.659^{* * *}$ & $0.001^{*}$ \\
\hline RIF specification error & $-0.710^{* *}$ & $-1.484^{* * *}$ & $-0.941^{* *}$ & $-1.561^{* * *}$ & -0.356 & 0.532 & 0.909 & -1.086 & 1.219 & 0.001 \\
\hline RIF earnings structure & $7.044^{* * *}$ & $10.995^{* * *}$ & $15.673^{* * *}$ & $21.357^{* * *}$ & $21.009^{* * *}$ & $24.607^{* * *}$ & $21.102^{* * *}$ & $36.240^{* * *}$ & $32.830^{* * *}$ & $-0.037^{* * *}$ \\
\hline RIF reweighting error & $-0.113^{* * *}$ & $-0.205^{* * *}$ & $-0.295^{* * *}$ & $-0.342^{* * *}$ & $-0.408^{* * *}$ & $-0.522^{* * *}$ & $-0.669^{* * *}$ & $-0.741^{* * *}$ & $-1.386^{* * *}$ & -0.000 \\
\hline \multicolumn{11}{|l|}{ RIF composition } \\
\hline Gender & $-0.235^{*}$ & $-0.366^{*}$ & $-0.418^{*}$ & $-0.427^{*}$ & $-0.449^{*}$ & $-0.515^{*}$ & $-0.598^{*}$ & $-0.696^{*}$ & $-0.950^{*}$ & 0.000 \\
\hline Education level & $0.778^{* * *}$ & $1.708^{* * *}$ & $2.369^{* * *}$ & $2.468^{* * *}$ & $2.536^{* * *}$ & $2.844^{* * *}$ & $3.502^{* * *}$ & $3.821^{* * *}$ & $5.821^{* * *}$ & $-0.001^{* * *}$ \\
\hline Age & $0.835^{* * *}$ & $1.126^{* * *}$ & $1.641^{* * *}$ & $2.059^{* * *}$ & $2.515^{* * *}$ & $3.499^{* * *}$ & $5.076^{* * *}$ & $5.387^{* * *}$ & $9.176^{* * *}$ & $0.002^{* * *}$ \\
\hline Routine task intensity & 0.156 & 0.281 & 0.350 & 0.396 & 0.492 & 0.661 & 0.919 & 0.954 & 1.612 & 0.000 \\
\hline Explained & $1.534^{* * *}$ & $2.750^{* * *}$ & $3.942^{* * *}$ & $4.496^{* * *}$ & $5.093^{* * *}$ & $6.489^{* * *}$ & $8.899^{* * *}$ & $9.466^{* * *}$ & $15.659^{* * *}$ & $0.001^{*}$ \\
\hline \multicolumn{11}{|l|}{ RIF earnings structure } \\
\hline Gender & -0.175 & -1.698 & 1.488 & -2.733 & $-3.771^{*}$ & $-5.361^{*}$ & $-8.013^{* * *}$ & $-17.162^{* * *}$ & -8.719 & -0.004 \\
\hline Education level & $15.224^{*}$ & $17.710^{* *}$ & $22.122^{* *}$ & 9.941 & 4.039 & 0.379 & 11.123 & 8.561 & 30.748 & -0.018 \\
\hline Age & $22.576^{* *}$ & $53.588^{* * *}$ & $61.006^{* * *}$ & 12.769 & $29.307^{*}$ & 33.302 & $49.332^{* *}$ & $67.034^{* * *}$ & 121.505 & -0.017 \\
\hline Routine task intensity & $1.875^{* *}$ & 2.410 & -2.208 & -0.809 & 1.289 & 3.222 & -4.665 & $-34.585^{* * *}$ & $-60.914^{* * *}$ & -0.010 \\
\hline Constant & $-32.455^{* *}$ & $-61.014^{* * *}$ & $-66.734^{* * *}$ & 2.189 & -9.855 & -6.935 & -26.676 & 12.392 & -49.790 & 0.013 \\
\hline Unexplained & $7.044^{* * *}$ & $10.995^{* * *}$ & $15.673^{* * *}$ & $21.357^{* * *}$ & $21.009^{* * *}$ & $24.607^{* * *}$ & $21.102^{* * *}$ & $36.240^{* * *}$ & $32.830^{* * *}$ & $-0.037^{* * *}$ \\
\hline Observations & 114,114 & 114,114 & 114,114 & 114,114 & 114,114 & 114,114 & 114,114 & 114,114 & 114,114 & 114,114 \\
\hline
\end{tabular}

Note: ${ }^{*} p<0.1,{ }^{* *} p<0.05,{ }^{* * *} p<0.01$

Source: authors' compilation based on data from ENAHO. 
Table A15: RIF inequality decomposition 2004-18 (real earnings)

\begin{tabular}{|c|c|c|c|c|c|c|c|c|c|c|}
\hline & $q 10$ & q20 & q30 & $\mathrm{q} 40$ & q50 & q60 & q70 & $\mathrm{q} 80$ & q90 & Gini \\
\hline \multicolumn{11}{|l|}{ Distribution } \\
\hline Final $\mathrm{F}$ & $41.997^{* * *}$ & $82.506^{* * *}$ & $125.412^{* * *}$ & $166.027^{* * *}$ & $201.770^{* * *}$ & $244.302^{* * *}$ & $297.904^{* * *}$ & $385.130^{* * *}$ & $539.766 * * *$ & $0.469^{* * *}$ \\
\hline Initial I & $25.222^{* * *}$ & $48.213^{* * *}$ & $72.300^{* * *}$ & $98.323^{* * *}$ & $126.654^{* * *}$ & $158.423^{* * *}$ & $200.209^{* * *}$ & $260.880^{* * *}$ & $364.193^{* * *}$ & $0.533^{* * *}$ \\
\hline Total Change F-I & $16.775^{* * *}$ & $34.293^{* * *}$ & $53.112^{* * *}$ & $67.704^{* * *}$ & $75.116^{* * *}$ & $85.879^{* * *}$ & $97.695^{* * *}$ & $124.251^{* * *}$ & $175.572^{* * *}$ & $-0.064^{* * *}$ \\
\hline \multicolumn{11}{|l|}{ Reweighting decomposition } \\
\hline Counterfactual C & $28.227^{* * *}$ & $53.291^{* * *}$ & $80.689^{* * *}$ & $110.299^{* * *}$ & $142.858^{* * *}$ & $178.282^{* * *}$ & $227.952^{* * *}$ & $288.468^{* * *}$ & $420.449^{* * *}$ & $0.541^{* * *}$ \\
\hline Total Composition C-I & $3.004^{* * *}$ & $5.078^{* * *}$ & $8.389^{* * *}$ & $11.976^{* * *}$ & $16.205^{* * *}$ & $19.859^{* * *}$ & $27.743^{* * *}$ & $27.588^{* * *}$ & $56.255^{* * *}$ & $0.008^{* *}$ \\
\hline Total Earnings structure F-C & $13.770^{* * *}$ & $29.215^{* * *}$ & $44.723^{* * *}$ & $55.728^{* * *}$ & $58.912^{* * *}$ & $66.020^{* * *}$ & $69.952^{* * *}$ & $96.663^{* * *}$ & $119.317^{* * *}$ & $-0.072^{* * *}$ \\
\hline \multicolumn{11}{|l|}{ RIF aggregate decomposition } \\
\hline RIF composition & $3.395^{* * *}$ & $6.145^{* * *}$ & $9.394^{* * *}$ & $13.373^{* * *}$ & $17.338^{* * *}$ & $20.565^{* * *}$ & $28.782^{* * *}$ & $35.460^{* * *}$ & $48.540^{* * *}$ & $0.011^{* * *}$ \\
\hline RIF specification error & -0.391 & $-1.067^{* *}$ & $-1.004^{*}$ & $-1.397^{* *}$ & -1.134 & -0.707 & -1.039 & $-7.872^{* * *}$ & $7.715^{* *}$ & $-0.003^{* * *}$ \\
\hline RIF earnings structure & $14.134^{* * *}$ & $29.879^{* * *}$ & $45.749^{* * *}$ & $57.143^{* * *}$ & $60.772^{* * *}$ & $68.489^{* * *}$ & $73.172^{* * *}$ & $99.521^{* * *}$ & $124.801^{* * *}$ & $-0.072^{* * *}$ \\
\hline RIF reweighting error & $-0.364^{* * *}$ & $-0.665^{* * *}$ & $-1.026^{* * *}$ & $-1.415^{* * *}$ & $-1.860^{* * *}$ & $-2.468^{* * *}$ & $-3.220^{* * *}$ & $-2.859^{* * *}$ & $-5.484^{* * *}$ & -0.000 \\
\hline \multicolumn{11}{|l|}{ RIF composition } \\
\hline Gender & $-0.650^{* * *}$ & $-0.940^{* * *}$ & $-1.141^{* * *}$ & $-1.275^{* * *}$ & $-1.366^{* * *}$ & $-1.514^{* * *}$ & $-1.606^{* * *}$ & $-1.625^{* * *}$ & $-3.570^{* * *}$ & -0.000 \\
\hline Education level & $2.177^{* * *}$ & $3.777^{* * *}$ & $5.822^{* * *}$ & $7.530^{* * *}$ & $8.454^{* * *}$ & $9.148^{* * *}$ & $11.500^{* * *}$ & $13.175^{* * *}$ & $19.647^{* * *}$ & -0.001 \\
\hline Age & $0.829^{* * *}$ & $1.160^{* * *}$ & $1.661^{* * *}$ & $2.478^{* * *}$ & $3.449^{* * *}$ & $4.323^{* * *}$ & $6.172^{* * *}$ & $7.568^{* * *}$ & $11.752^{* * *}$ & $0.004^{* *}$ \\
\hline Routine task intensity & $1.040^{* * *}$ & $2.149^{* * *}$ & $3.052^{* * *}$ & $4.640^{* * *}$ & $6.802^{* * *}$ & $8.609^{* * *}$ & $12.715^{* * *}$ & $16.342^{* * *}$ & $20.712^{* * *}$ & $0.009^{* * *}$ \\
\hline Explained & $3.395^{* * *}$ & $6.145^{* * *}$ & $9.394^{* * *}$ & $13.373^{* * *}$ & $17.338^{* * *}$ & $20.565^{* * *}$ & $28.782^{* * *}$ & $35.460^{* * *}$ & $48.540^{* * *}$ & $0.011^{* * *}$ \\
\hline \multicolumn{11}{|l|}{ RIF earnings structure } \\
\hline Gender & $9.906^{* * *}$ & $15.136^{* * *}$ & $19.818^{* * *}$ & $12.487^{* * *}$ & $11.704^{* * *}$ & $14.442^{* * *}$ & $20.145^{* * *}$ & $14.429^{* * *}$ & -1.862 & $-0.036^{* * *}$ \\
\hline Education level & 4.288 & $29.933^{* * *}$ & $26.360^{* * *}$ & 0.853 & -3.085 & -0.615 & $20.755^{* *}$ & $33.045^{* * *}$ & $37.972^{*}$ & 0.011 \\
\hline Age & $45.964^{* * *}$ & $87.833^{* * *}$ & $91.922^{* * *}$ & $43.913^{* * *}$ & 17.449 & $44.218^{* *}$ & $94.675^{* * *}$ & $152.388^{* * *}$ & $234.487^{* * *}$ & 0.106 \\
\hline Routine task intensity & $-5.235^{* * *}$ & $-8.381^{* * *}$ & $-12.203^{* * *}$ & $-3.123^{*}$ & 0.155 & 2.010 & -0.587 & $-43.861^{* * *}$ & $-79.992^{* * *}$ & 0.002 \\
\hline Constant & $-40.789^{* * *}$ & $-94.642^{* * *}$ & $-80.149^{* * *}$ & 3.012 & $34.550^{* *}$ & 8.434 & $-61.817^{*}$ & -56.480 & -65.803 & $-0.154^{* *}$ \\
\hline Unexplained & $14.134^{* * *}$ & $29.879^{* * *}$ & $45.749^{* * *}$ & $57.143^{* * *}$ & $60.772^{* * *}$ & $68.489^{* * *}$ & $73.172^{* * *}$ & $99.521^{* * *}$ & $124.801^{* * *}$ & $-0.072^{* * *}$ \\
\hline Observations & 104,462 & 104,462 & 104,462 & 104,462 & 104,462 & 104,462 & 104,462 & 104,462 & 104,462 & 104,462 \\
\hline
\end{tabular}

Note: ${ }^{*} p<0.1,{ }^{* *} p<0.05,{ }^{* * *} p<0.01$

Source: authors' compilation based on data from ENAHO. 
Figure A2: RIF inequality decomposition 2004-2011 (real earnings) (a) RIF aggregate decomposition

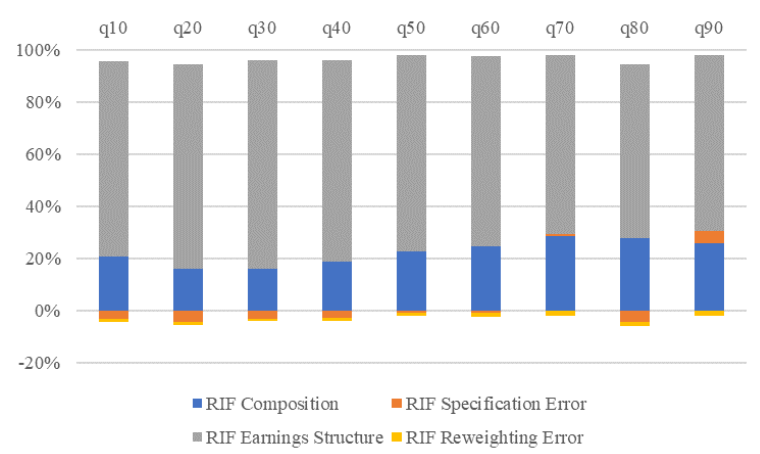

(b) Reweighting decomposition

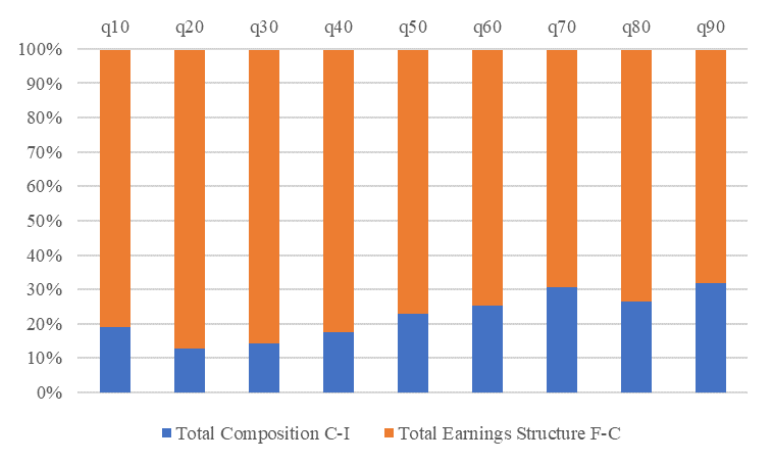

(c) RIF composition

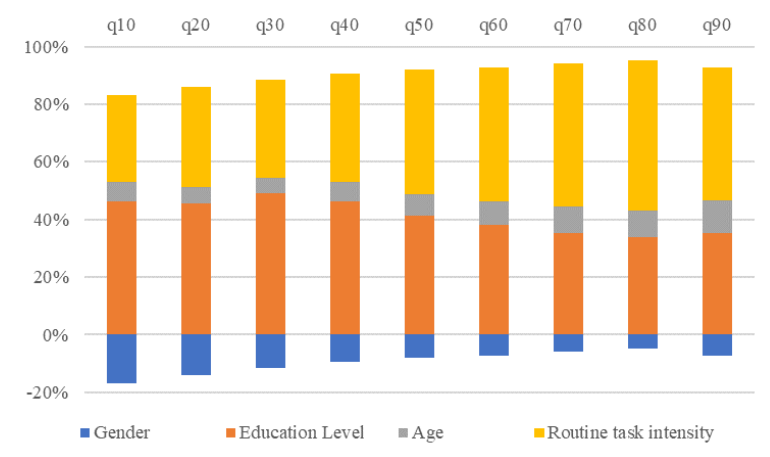

(d) RIF earnings structure

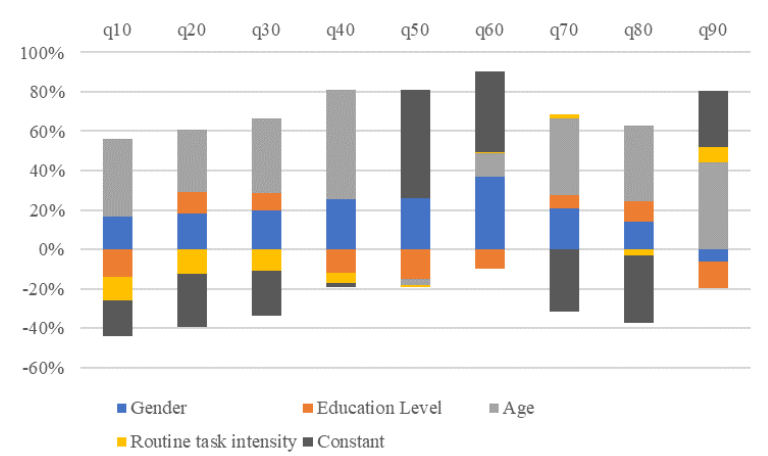

Source: authors' compilation based on data from ENAHO. 
Figure A3: RIF inequality decomposition 2011-18 (real earnings) (a) RIF aggregate decomposition

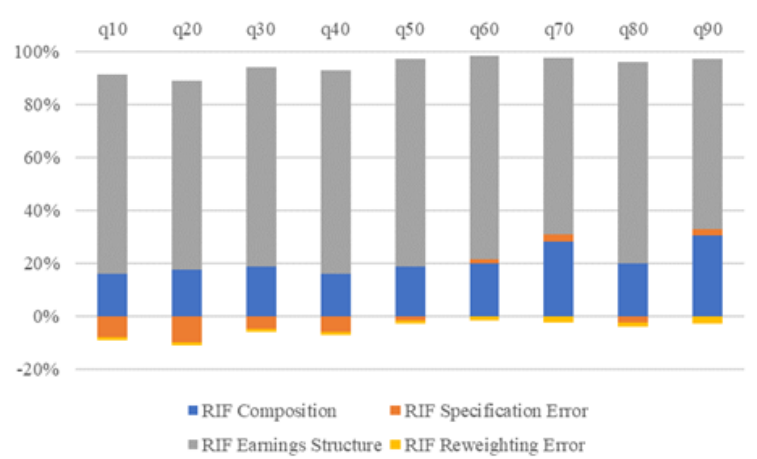

(b) Reweighting decomposition

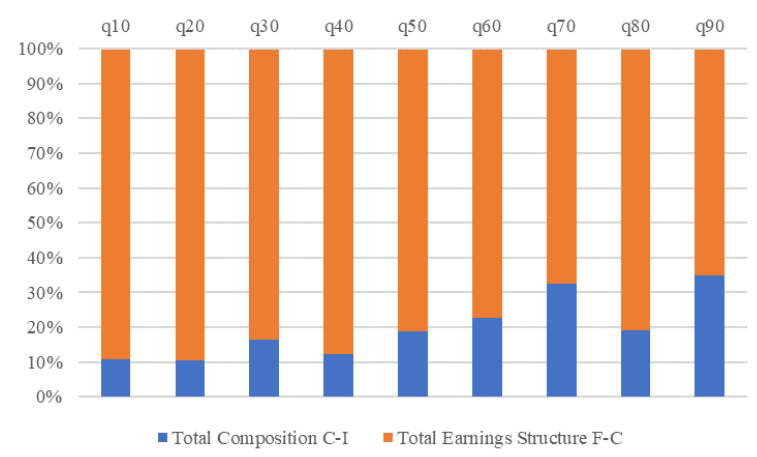

(c) RIF composition

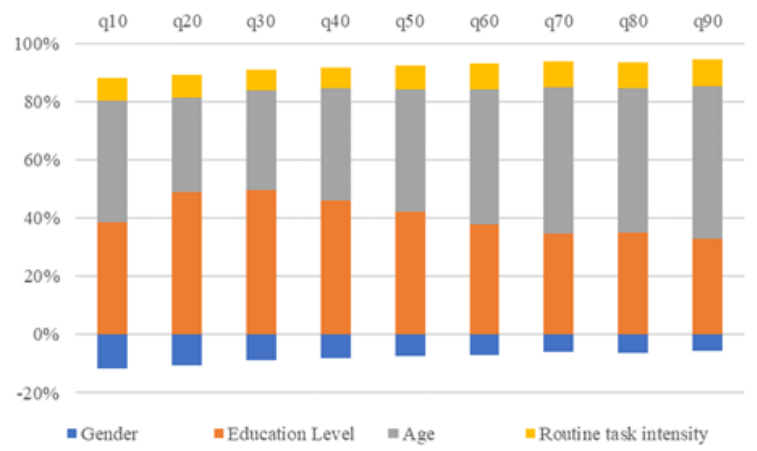

(d) RIF earnings structure

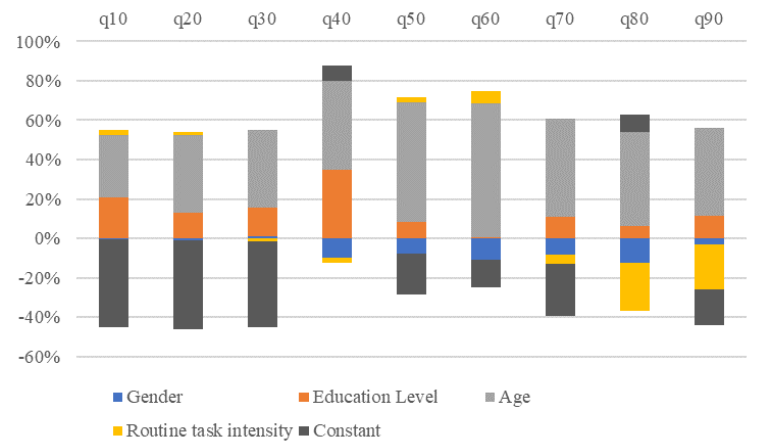

Source: authors' compilation based on data from ENAHO. 
Figure A4: RIF inequality decomposition 2004-18 (real earnings) (a) RIF aggregate decomposition

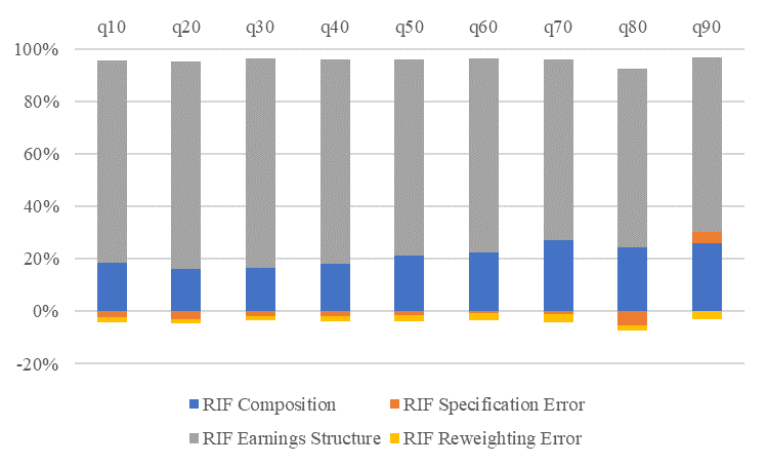

(b) Reweighting decomposition

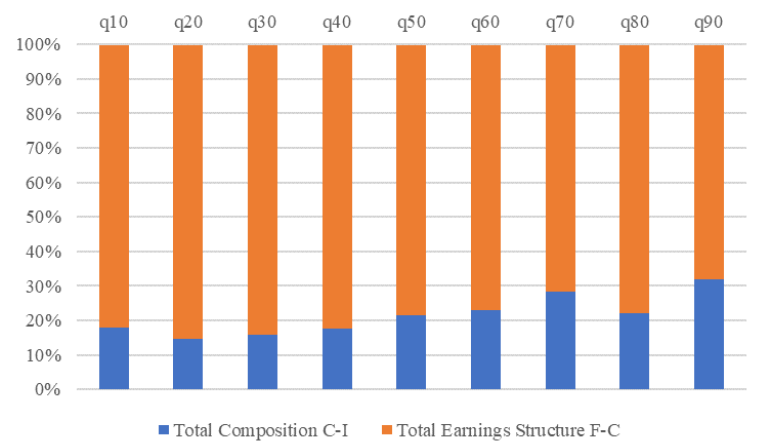

(c) RIF composition

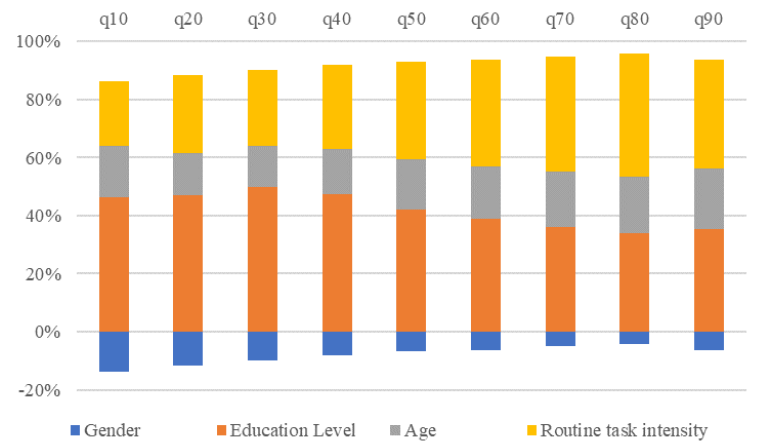

(d) RIF earnings structure

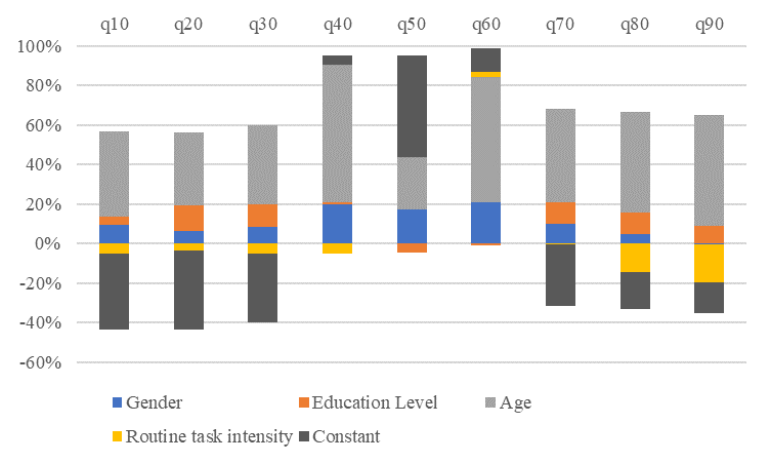

Source: authors' compilation based on data from ENAHO. 
Table A16: Technical coefficients: $A$ matrix

\begin{tabular}{llcccccccc}
\hline & Agriculture & fishing & Mining & Manufacture & Elect. \& water & Construction & Commerce & Government & services \\
\hline Agriculture & 0.09 & 0.00 & 0.00 & 0.07 & 0.00 & 0.00 & 0.00 & 0.00 & 0.01 \\
Fishing & 0.00 & 0.01 & 0.00 & 0.01 & 0.00 & 0.00 & 0.00 & 0.00 & 0.00 \\
Mining & 0.00 & 0.00 & 0.05 & 0.09 & 0.04 & 0.02 & 0.00 & 0.00 & 0.00 \\
Manufacture & 0.09 & 0.29 & 0.12 & 0.20 & 0.10 & 0.40 & 0.90 & 0.18 & 0.15 \\
Elect. \& water & 0.00 & 0.01 & 0.02 & 0.01 & 0.11 & 0.00 & 0.14 & 0.02 & 0.01 \\
Construction & 0.00 & 0.00 & 0.00 & 0.00 & 0.01 & 0.02 & 0.01 & 0.02 & 0.00 \\
Commerce & 0.00 & 0.00 & 0.00 & 0.00 & 0.00 & 0.00 & 0.03 & 0.01 & 0.01 \\
Government & 0.00 & 0.00 & 0.00 & 0.00 & 0.00 & 0.00 & 0.00 & 0.00 & 0.00 \\
Services & 0.02 & 0.06 & 0.10 & 0.04 & 0.12 & 0.05 & 2.89 & 0.19 & 0.19 \\
\hline
\end{tabular}

Source: authors' compilation based on data published by INEI.

Table A17: Multipliers coefficients: $(I-A)^{-1}$ matrix

\begin{tabular}{llcccccccc}
\hline & Agriculture & Fishing & Mining & Manufacture & Elect. \& water & Construction & Commerce & Government & Services \\
\hline Agriculture & 1.11 & 0.03 & 0.02 & 0.10 & 0.02 & 0.04 & 0.19 & 0.03 & 0.03 \\
Fishing & 0.00 & 1.01 & 0.00 & 0.02 & 0.00 & 0.01 & 0.03 & 0.01 & 0.00 \\
Mining & 0.01 & 0.04 & 1.07 & 0.12 & 0.07 & 0.07 & 0.20 & 0.03 & 0.03 \\
Manufacture & 0.14 & 0.40 & 0.20 & 1.31 & 0.22 & 0.56 & 2.09 & 0.34 & 0.29 \\
Elect. \& water & 0.00 & 0.02 & 0.03 & 0.02 & 1.13 & 0.01 & 0.23 & 0.03 & 0.02 \\
Construction & 0.00 & 0.00 & 0.00 & 0.00 & 0.01 & 1.02 & 0.02 & 0.02 & 0.00 \\
Commerce & 0.00 & 0.00 & 0.01 & 0.00 & 0.01 & 0.00 & 1.09 & 0.02 & 0.02 \\
Government & 0.00 & 0.00 & 0.00 & 0.00 & 0.00 & 0.00 & 0.00 & 1.00 & 0.00 \\
Services & 0.04 & 0.11 & 0.16 & 0.09 & 0.22 & 0.11 & 4.07 & 0.34 & 1.33 \\
\hline
\end{tabular}

Source: authors' compilation based on data published by INEI 